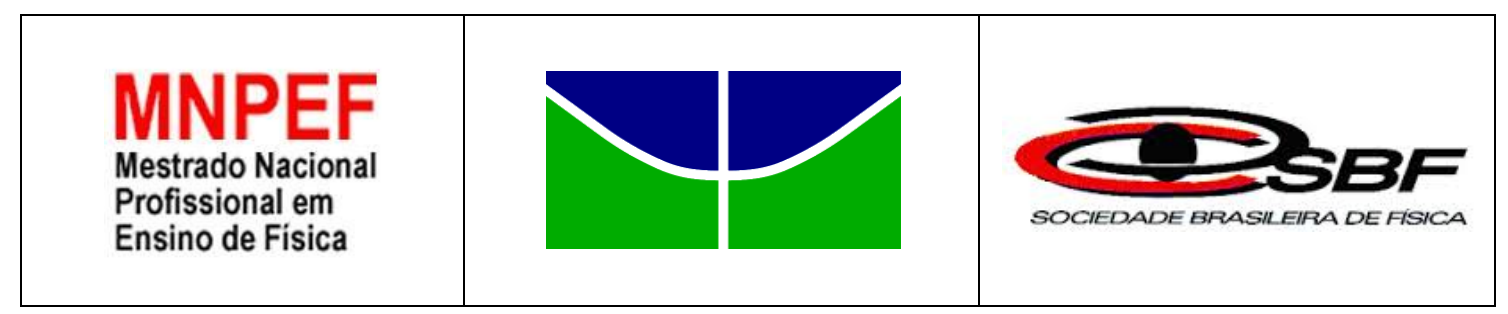

CONSTRUÇÃO DE INSTRUMENTOS DE OBSERVAÇÃO ASTRONÔMICA PARA O ENSINO DE ÓPTICA GEOMÉTRICA

JEFFERSON DE SOUSA PEREIRA

Dissertação de Mestrado apresentada ao Programa de Pós-Graduação da Universidade de Brasília no Curso de Mestrado Nacional Profissional de Ensino de Física (MNPEF), como parte dos requisitos necessários à obtenção do título de Mestre em Ensino de Física.

Orientador:

Prof. Dr. Wytler Cordeiro dos Santos

Brasília

Dezembro de 2016 


\title{
CONSTRUÇÃO DE INSTRUMENTOS DE OBSERVAÇÃO ASTRONÔMICA PARA O ENSINO DE ÓPTICA GEOMÉTRICA
}

\author{
JEFFERSON DE SOUSA PAREIRA \\ Orientador: \\ Prof. Dr. Wytler Cordeiro dos Santos
}

Dissertação de Mestrado submetida ao Programa de Pós-Graduação da Universidade de Brasília no Curso de Mestrado Nacional Profissional de Ensino de Física (MNPEF), como parte dos requisitos necessários à obtenção do título de Mestre em Ensino de Física

Aprovada por:

Dr. Wytler Cordeiro dos Santos

(Orientador e Presidente IF/UnB)

Dr. José Leonardo Ferreira

(Membro Titular Interno - IF/UnB)

Dr. Caio Marcello Mota Polito

(Membro Titular externo - CMB)

Dr. Ronni Geraldo Gomes de Amorim

(Membro Suplente Interno - IF/UnB)

Brasília

Dezembro de 2016 
Pereira, Jefferson de Sousa

Construção de instrumentos de observação astronômica para o ensino de Óptica Geométrica/ Jefferson de Sousa Pereira - Brasília: UnB / IF, 2016.

viii, 77 f.: il.; $30 \mathrm{~cm}$.

Orientador: Wytler Cordeiro dos Santos

Dissertação (mestrado) - UnB / Instituto de Física / Mestrado

Profissionalizante em Ensino de Física, 2016.

Referências Bibliográficas: f. 52-53.

1. Ensino de Física. 2. Astronomia. 3. Equipamentos de observação. I. Santos, Wytler Cordeiro dos. II. Universidade de Brasília, Instituto de Física, Mestrado Nacional Profissionalizante em Ensino de Física. III. Construção de instrumentos de observação astronômica para o ensino de Óptica Geométrica. 
Dedico esta dissertação a Deus, pela oportunidade de viver e pela força que me tem concedido de chegar até aqui. Ao bom Deus toda honra, glória e louvor para sempre! 


\section{Agradecimentos}

Agradeço:

À CAPES pelo apoio financeiro por meio da bolsa concedida.

A SBF pela iniciativa de oferecer essa grande oportunidade de aprendizagem. Aos meus pais, pela boa educação a mim concedida.

À minha esposa, por seu amor e carinho para comigo.

Aos meus colegas, em especial Laelton, Jorge, William, Ueslei e Itevaldo pelo companheirismo.

Aos professores do Departamento de física da UnB por suas aulas valiosas.

E principalmente ao meu querido orientador, pelos ensinamentos, pelo apoio e pela amizade e dedicação ao longo desses anos. 


\title{
RESUMO \\ CONSTRUÇÃO DE EQUIPAMENTOS DE OBSERVAÇÃO ASTRONOMICA NO ENSINO DE ÓPTICA GEOMÉTRICA
}

\author{
Jefferson de Sousa Pereira \\ Orientador: \\ Wytler Cordeiro dos Santos
}

Dissertação de Mestrado submetida ao Programa de Pós-Graduação da Universidade de Brasília no Curso de Mestrado Nacional Profissionalizante de Ensino de Física (MNPEF), como parte dos requisitos necessários à obtenção do título de Mestre em Ensino de Física

O ensino de Astronomia está cada vez mais extinto nos currículos escolares. Por essa razão, acreditamos que inserir tópicos de Astronomia nas aulas de Física de maneira interdisciplinar é uma estratégia viável para que os alunos tenham contato com o tema. É a partir desta proposta que foram elaboradas aulas de Óptica Geométrica, com o intuito de montar lunetas galileanas (telescópios refletores), as quais foram aplicadas numa escola pública da cidade do Paranoá no Distrito Federal, em duas turmas de $2^{\circ}$ ano do Ensino Médio. Ainda sim, dividimos essas aulas em duas etapas: momento tradicional - conteúdo de princípios da natureza da luz e espelhos (planos e esféricos) e aulas tradicionais - e momento prático - com conteúdo de refração da luz e lentes esféricas e aulas direcionadas à montagem da luneta galileana e oficina de montagem do equipamento com observação astronômica. Foram feitas avaliações nos dois momentos, a fim de realizar uma análise do desempenho dos alunos em cada um dos momentos, comparando as duas estratégias de ensino.

Palavras-chave: Ensino de Física, Observação Astronômica, Construção de Equipamentos, Óptica Geométrica.

Brasília

Julho de 2016 


\author{
ABSTRACT \\ CONSTRUCTION OF ASTRONOMICAL OBSERVATION INSTRUMENTS FOR \\ GEOMETRICAL OPTICS TEACHING \\ Jefferson de Sousa Pereira \\ Supervisor: \\ Wytler Cordeiro dos Santos
}

\begin{abstract}
Programa de Pós-Graduação da Universidade de Brasília in Mestrado Profissional de Ensino de Física (MNPEF) Course, as part to of the requirements for obtaining the Master's title in Physics Teaching.
\end{abstract}

The astronomy education is increasingly extinct curricula. For this reason we believe that enter astronomical topics in physics classes in an interdisciplinary way is more feasible for students to have contact with the subject. It is with this view that elaborate geometric optics classes aiming to assemble Galilean telescopes (reflecting telescopes), and apply those lessons in a public school Paranoá city in the Federal District, in two groups of 2nd year of high school. Still, we divided these classes into two stages: the traditional time - the traditional classes and content principles of the nature of light and mirrors (flat and spherical) - and practical time - with refractive contents from light and spherical lenses, with classes aimed at Mount Galilean telescope and finally the equipment assembly workshop with astronomical observation. Evaluations were made on both occasions, in order to conduct a performance assessment of students in each of the moments, comparing the two teaching strategies.

Keywords: Physics education, Astronomical observation, Construction equipment, Geometric optics.

Brasília

December 2016 


\section{Sumário}

\section{Capítulo 1}

Introdução Teórica

1.1 Sobre o Mestrado Nacional Profissionalizante em Ensino de Física MNPEF 1

1.2 A formação de professores 2

$\underline{1.3 \mathrm{O} \text { ensino de Astronomia }} 5$

$1.4 \mathrm{O}$ ensino de Óptica Geométrica $\quad 9$

1.4.1 Aspectos históricos da evolução dos conceitos da Óptica 9

1.4.2 Aspectos pedagógicos da Óptica Geométrica 14

1.5 Justificativa do projeto 15

Capítulo 2.

Elaboração dos instrumentos ópticos 17

\begin{tabular}{lr}
2.1 Luneta Galileana & 17 \\
\hline
\end{tabular}

2.1.1 Aspectos Históricos 17

\begin{tabular}{ll} 
2.1.2 Lentes esféricas & 18 \\
\hline
\end{tabular}

\begin{tabular}{ll} 
2.1.3 Projeto piloto & 21 \\
\hline
\end{tabular}

\begin{tabular}{ll}
2.1 .4 Versão final & 23 \\
\hline
\end{tabular}

Capítulo 3

\begin{tabular}{ll} 
Aplicação em sala de aula & 28 \\
\hline
\end{tabular}

3.1 Cenário tradicional 29

\begin{tabular}{lr}
3.2 Cenário prático & 30 \\
\hline
\end{tabular}

\begin{tabular}{lr}
3.2 .1 Primeira aula & 30 \\
\hline
\end{tabular}

\begin{tabular}{ll} 
3.2.2 Segunda aula & 33 \\
\hline
\end{tabular}

\begin{tabular}{ll}
3.2 .3 Terceira aula & 34 \\
\hline
\end{tabular}

3.2.4 Quarta aula 35

\begin{tabular}{lr}
3.2 .5 Quinta aula & 38 \\
\hline
\end{tabular} 
Capítulo 4

$\underline{\text { Resultados obtidos e Análises }}$

4.1 Avaliações quantitativas

4.1.1 Teste 1 40

4.1.2 Teste 2 40

4.1.3 Prova 41

4.1.4 Diagnóstico das avaliações 42

4.2 Avaliações qualitativas 45

4.2.1 Lista de exercícios 45

4.2.2 Texto dissertativo 45

Capítulo 5

Considerações finais 48

Referências Bibliográficas 52

Apêndice A

Teste 1 .. 54

Apêndice B

Teste 2

Apêndice C

Lista de exercícios 56

Apêndice D

Prova

Apêndice E

Produto educacional 58 


\section{Lista de Tabelas}

Tabela 1.1 - Mestrados e Doutorados reconhecidos. Fonte: CAPES.............................. 1

Tabela 4.1 - Opinião dos alunos quanto ao trabalho desenvolvido. Fonte: Autor......... 46 


\section{Lista de Figuras}

Figura 2.1 - Imagem formada por uma lente convergente. Fonte: Autor...................... 18

Figura 2.2 - Imagem formada por uma lente convergente. Fonte: Autor..................... 19

Figura 2.3 - Imagem formada por uma lente convergente. Fonte: Autor..................... 19

Figura 2.4 - Imagem formada por uma lente convergente. Fonte: Autor.................... 19

Figura 2.5 - Imagem formada por uma lente convergente. Fonte: Autor...................... 20

Figura 2.6 - Imagem formada por uma lente divergente. Fonte: Autor..................... 20

Figura 2.7 - Imagem formada pela associação de lente. Fonte: Autor....................... 21

Figura 2.8 - Imagem formada pela associação de lente. Fonte: Autor..................... 21

Figura 2.9 - Esquema representativo dos raios de luz numa luneta. Fonte: Autor........ 22

Figura 2.10 - Anel de tubo de 40 mm. Fonte: Autor....................................................24

Figura 2.11 - Colagem dos anéis de tubo de 40 mm. Fonte: Autor............................. 25

Figura 2.12 - Fita isolante para melhor ajuste entre os dois tubos. Fonte: Autor.......... 25

Figura 2.13 - Acoplagem da lente objetiva ao tubo de $50 \mathrm{~mm}$. Fonte: Autor............... 26

Figura 2.14 - Acoplagem da lente ocular na redução de 50 mm x 32. Fonte: Autor .....26

Figura 2.15 - Montagem final do tubo de 40 mm.. Fonte: Autor................................ 27

Figura 2.16 - Luneta montada. Fonte: Autor...................................................... 27

Figura 3.1 - Experimento de refração. Fonte: Autor................................................... 31

Figura 3.2 - "L" da luneta e as peças que a compõem. Fonte: Autor............................ 32

Figura 3.3 - Foto da decomposição da luz. Fonte: Autor...............................................32 
Figura 3.4 - Orientações para montagem da luneta. Fonte: Autor..

Figura 3.5 - Professor e aluno trabalhando na luneta. Fonte: Autor............................ 37

Figura 3.6 - Observação na quadra poliesportiva da escola. Fonte: Autor.................... 38 


\section{Lista de Gráficos}

Figura 4.1 - Gráfico do desempenho da turma 2E nas três avaliações. Fonte: Autor.... 43

Figura 4.2 - Gráfico do desempenho geral da turma 2E. Fonte: Autor 43

Figura 4.3 - Gráfico o desempenho da turma 2F nas três avaliações. Fonte: Autor...... 44

Figura 4.4 - Gráfico o desempenho geral da turma 2F. Fonte: Autor. 44

Figura 4.5 - Gráfico da opinião dos alunos sobre o trabalho. Fonte: Autor. 47 


\section{Capítulo 1}

\section{Introdução Teórica}

\subsection{Sobre o Mestrado Nacional Profissionalizante em Ensino de Física MNPEF}

A formação continuada dos professores nas universidades do país tem sido muito ligada à área acadêmica, bem como à produção intelectual. Produção intelectual entende-se pela produção de artigos e trabalhos ligados a pesquisas básicas, que dão suporte para o trabalho de outros pesquisadores, bem como para a área aplicada.

A história dos mestrados profissionalizantes no Brasil se inicia no ano 2000, com a criação dos mestrados em ensino - o ensino de ciências e matemática, similar ao mestrado acadêmico, como também os doutorados, a fim de intensificar as pesquisas nessas áreas e com intuito de melhorar a qualidade do ensino no país. Ainda na área das ciências e matemática, em 2002, foram abertos os primeiros mestrados profissionalizantes em ensino, com o objetivo de buscar a aplicação em sala de aula e obtenção de um produto educacional gerado a partir da utilização de novas estratégias propostas pelos mestrandos e seus impactos na qualidade do ensino.

Atualmente, existem cento e dezenove cursos de mestrados na área do ensino, entre mestrados profissionais e acadêmicos em diversas áreas, reconhecidos segundo a CAPES (Coordenação de Aperfeiçoamento de Pessoal de Ensino Superior). Observa-se que o número de cursos de mestrados profissionais é maior que o número de mestrados acadêmicos [CAPES, 2015], como pode ser visto na Tabela 1.1 abaixo:

\begin{tabular}{|c|c|c|c|c|c|c|c|c|c|c|}
\hline \multicolumn{8}{|c|}{ Mestrados e Doutorados reconhecidos } \\
\hline \multirow{2}{*}{ ÁREA } & \multicolumn{3}{|c|}{ Programas e Cursos de pós-graduação } & \multicolumn{3}{c|}{ Totais de Cursos de pós- } \\
graduação
\end{tabular}

Tabela 1.1: Mestrados e doutorados em ensino reconhecidos pela CAPES 
O Mestrado Nacional Profissionalizante em Ensino de Física (MNPEF) é destinado a professores em atuação na educação básica ou no Ensino Médio e voltado à pesquisa aplicada com enfoque nos conteúdos disciplinares trabalhados prioritariamente em sala de aula (ou laboratório didático), e devem gerar produtos educacionais que possam ser usados por outros professores (MOREIRA, 2014). Nesta perspectiva, o aprofundamento bibliográfico se caracteriza enquanto direcionador, na medida em que se mantém relevante ao produto intelectual.

No entanto, a ênfase desse trabalho está na experiência da implementação de estratégias didáticas propostas pelo mestrando, a fim de gerar o produto educacional que possa ser utilizado posteriormente por outros professores de forma eficaz, constituindo assim uma grande contribuição para a educação básica no Brasil, particularmente a esses profissionais (MOREIRA, 2014). Sendo assim, houve a necessidade de se fazer uma distinção entre mestrado acadêmico e mestrado profissionalizante, apresentando suas características, objetivos e contribuições na melhoria do ensino no país.

\subsection{A formação de professores}

O ensino de ciências em especial tem passado por mudanças significativas, que podem ser notadas em atuações nas escolas públicas ao passar do tempo. Essas mudanças foram possíveis graças a uma nova geração de professores que vem se formando nos dias atuais, isso por que (sem generalizar, salvo algumas exceções) notase ao atuar nesses estabelecimentos que professores mais antigos da educação básica tendem a se acomodar na rotina repetitiva de método de ensino, lecionando as mesmas aulas (em sua maioria tradicional e expositiva), adequando-se ao sistema de ensino, que os "aconchegam" mais ainda na maioria das situações.

A "lei do menor esforço" (em geral é inerente ao ser humano) aponta que é mais cômodo utilizar sempre os mesmos métodos e as mesmas notas de aula ano após ano, de maneira que novos métodos e novas estratégias nem sempre são introduzidas em sala de aula. Consequentemente, os alunos são acomodados em um sistema educacional vicioso (tanto por parte desses professores como de outros integrantes do corpo escolar), pois ao longo de sua carreira escolar descobrem o "jeitinho" (estratégias colaterais) de conseguir sucesso nas avaliações e assim cumprir a meta que supõem ser o seu grande objetivo: aprovação, em detrimento de uma aprendizagem significativa e eficaz.

É interessante notar que o sistema de ensino é regido por algo que pesquisadores chamam de contrato didático, envolvido na relação professor-aluno, a qual está 
subordinada a regras e convenções, que funcionam como se fossem cláusulas de um contrato oculto, mas que todos têm como norma (SILVA, 2008) Neste sentido, basicamente, o professor tem a função e responsabilidade de dar aulas expositivas e passar exercícios; em contrapartida, os alunos têm que reproduzir semelhantemente tudo que o professor fez nos exercícios e na prova. Dessa maneira, pode-se afirmar então que esse sistema educacional apresenta uma rotina viciada.

A partir do momento que um professor recém formado chega às escolas públicas, depara-se então com o sistema já formado, com a "máquina educacional rodando" com seus vícios e defeitos. As regras da escola já estão estabelecidas, as estratégias dos outros professores também, e os alunos estão acomodadamente passivos nesse contrato didático. Em casos de professores que gostariam de propor novos métodos, o engajamento e a força de vontade terão que ser grandes para que não se alinhem ao sistema, e tornem-se assim peças de uma máquina educacional viciada, isto por que sofrem oposições fortes por parte da comunidade escolar:

- colegas professores que muitas vezes vê o professor novato como ameaça ao seu estado de comodismo. É comum ouvir-se: “chegou agora e já quer dizer aos outros o que fazer";

- alunos que vêm o professor novato como um inexperiente, que ainda não sabe ensinar, e que irão sofrer pela suposta falta de experiência desse professor. É comum ouvir-se: "chegou agora e não sabe nem se fica e já quer impor novas regras";

- pais de alunos que ao sentirem a insegurança dos filhos se sentem na obrigação de os defenderem. É comum ouvir-se: “esse professor não sabe dar aula, vamos ficar de olho nele";

- membros da direção da escola que ao se depararem com a insatisfação de parte da comunidade escolar, passam a enxergar o professor novato como um grande problema. É comum ouvir-se: "esses professores recém formados acham que vão resolver todos os problemas do mundo, mas acabam se tornando um problema".

Para o caso de professores da rede pública de ensino, os que não se submetem ao sistema da forma como funciona, têm por desafio uma difícil adaptação durante os dois primeiros anos do seu magistério (estágio probatório sujeito à exoneração), para se enquadrar na escola e ao mesmo tempo não cair na rotina tradicional imposta. Com o 
passar do tempo, o professor que deseja mudanças para melhor vai adquirindo autoconfiança, e,juntamente com a estabilidade de trabalho, torna-se possível por em prática suas propostas e convicções pedagógicas.

\subsubsection{Formação Continuada}

O professor que recentemente tenha concluído a graduação sabe que existem grandes desafios para se tornar um bom educador - um professor com excelência na arte de ensino, que quer o bem dos alunos e da prática educativa que participa (FREIRE, 1996).Para isso, um professor (em qualquer área) tem a necessidade de constantemente atualizar seus conhecimentos.

Por exemplo, o LIGO (Laser Interfesometer of Gravitation Wave Observer) (LIGO LAB, 2015), detectou pela primeira vez as ondas gravitacionais em setembro de 2015 e divulgou os resultados em fevereiro de 2016; os alunos do primeiro semestre de 2016 irão recorrer aos professores de Física de suas escolas, questionando-os a respeito do experimento; o professor de Física tem por obrigação estar informado sobre o assunto; a experiência mostra que quando o aluno questiona o professor e ele não entende o assunto em questão, tanto o aluno quanto o professor ficam no vazio do conhecimento. Este exemplo caracteriza como existe a necessidade do professor estar constantemente estudando novos tópicos e revisando os conteúdos.

Rodolfo Langhi e Roberto Nardi fazem um bom comentário sobre a formação dos professores em seu livro Educação em Astronomia: repensando a formação de professores (LANGHI E NARDI, 2012), em que sintetizam a formação do professor em quatro partes:

- Formação Pessoal: um auto desenvolvimento. Intrínseco de cada pessoa.

- Formação Científica: conhecimento da área ou disciplina a qual o professor se especializa.

- Formação Pedagógico-Didática: ferramentas essenciais para formação do didata.

- Prática Pedagógica: obtenção de experiência a partir da realização do trabalho docente.

Os autores ainda expõem que a formação de um professor começa antes mesmo de seu curso de graduação. Isto é, experiências vividas no Ensino Fundamental e médio influenciam no seu modo de ensinar, pois nessa etapa o futuro didata costuma se afeiçoar ao modo de ensinar de algum professor, o que possivelmente possa ter 
incentivado de forma significativa a sua escolha profissional. Tal escolha pode ter sido influenciada também pela família, ou pelo simples fato de ter facilidade em ajudar os colegas nas matérias enquanto estudante.

Partindo dos pressupostos citados acima, pode-se deduzir de maneira mais complementada a trajetória de formação do docente, a qual os autores [LANGH e NARDI, 2012] dividem em quatro grandes fases de formação:

l. Trajetória formativa inicial: experiência de vida pessoal, familiar, social e escolar.

11. Trajetória formativa intermediária: na universidade no curso acadêmico de formação de professores.

111. Trajetória formativa na carreira: experiências obtidas durante a profissão seja em sala de aula ou em cursos de formação continuada.

1๗. Trajetória pós-carreira: mesmo depois de ter finalizado a carreira e se aposentado, o professor não deixa de continuar se capacitando, não se permitindo parar no tempo.

A profissionalização do professor está ligada a validação do seu saber. Alguns autores fazem distinção entre o saber e o conhecimento (LANGH e NARDI, 2012). Conhecimento seria algo elaborado por pesquisadores e teóricos, enquanto o saber é adquirido e elaborado pelo próprio indivíduo em suas experiências pessoais.

Os saberes necessários para a prática docente podem ser divididos em:

- Saberes acadêmicos: são os saberes disciplinares, saberes curriculares, saberes pedagógicos.

- Saberes profissionais: experiência da profissão, saberes culturais e saberes pessoais.

- Saberes do meio inserido: Saber sobre os alunos e saber sobre a comunidade que o cerca.

Esses conjuntos de saberes são essenciais na hora do planejamento de ensino.

\subsection{0 ensino de Astronomia}

Ensinar Astronomia nas escolas é uma tarefa pouquíssima explorada. Ao se tentar inserir aulas de Astronomia no Ensino Fundamental e Ensino Médio, somos constantemente questionados, por exemplo, pela coordenação e direção das escolas, do porquê e dos benefícios de ensinar Astronomia. Tal questionamento é geralmente baseado no fato deste tema não ser cobrado em vestibulares, concursos, etc., o que torna 
o estudo de tópicos de Astronomia distante e fora do cotidiano dos alunos. Ainda assim,coordenações escolares e os próprios professores de Física questionam a viabilidade de se acrescentar tópicos sobre Astronomia aos currículos escolares, principalmente por razões de tempo, pois são poucas as aulas para os conteúdos que já são trabalhados.

De acordo com Langhi e Nardi (2012), não só no Brasil, mas em todo mundo, o ensino de Astronomia tem dificuldades de ser apresentado na escola básica, secundarista e ainda nas universidades. São poucos países que apresentam esse tópico na formação de crianças e adolescente, sem mencionar a formação em nível superior, nas universidades em todo o mundo. Ainda assim, alguns países desenvolveram estratégias que permitem em pequena escala o ensino desses conteúdos (LANGHI e NARDI, 2012) como, por exemplo:

- os EUA se destacam com mais trabalhos que citam o desenvolvimento do ensino de Astronomia. Alguns órgãos como NASA, National Optical Astronomy Observatory, Astronomy Society of the Pacific, e American Astronomical Society, mantém até periódicos de pesquisa;

- na Alemanha, há interesse dos estudantes pelo estudo do universo, mas os currículos não trazem esse tema. Nesse país, a Astronomia é predominantemente trabalhada no curso de formação inicial nas universidades. Além disso, existem cursos oferecidos por órgãos e associações de astrônomos profissionais e amadores;

- no Japão,os currículos de ciência contêm uma disciplina chamada Ciências da Terra, com quase 140 horas-aulas de duração. Nessa matéria encontram-se alguns tópicos de Astronomia, embora as maiorias das escolas de Ensino Médio não ofereçam essa matéria, com a desculpa de que esse conteúdo não é cobrado nos exames de admissão das universidades japonesas;

- na Bulgária, os conteúdos de Astronomia são inseridos na disciplina de Física;

- na França, até a década de 70 do século XX, não existiam conteúdos de Astronomia, mas com intervenções das Associações de Astronomia desse país foram inseridos temas interdisciplinares de Astronomia. Para a 
formação dos professores de Física, a disciplina de Astronomia é oferecida, além de cursos de verão com tópicos de Astronomia;

- no México, são trabalhados tópicos de Astronomia na formação continuada de professores de Física.

Ainda de acordo com Langhi e Nardi (2012), no Brasil houve um tempo em que a Astronomia era introduzida no ensino da ciência. Em 1942 (com o estado novo) houve a reforma dos currículos e a Astronomia foi retirada de disciplina específica. Na antiga Universidade do Brasil, havia o curso de graduação de Astronomia.

Nos dias atuais, a Universidade de São Paulo (USP) tem um Departamento de Astronomia (IAGCA, 2015), a Universidade Federal do Rio Grande do Sul (UFRS), no Instituto de Física também tem um Departamento de Astronomia (DAIF-UFRGS, 2015) juntamente com a Universidade Federal do Rio de Janeiro (UFRJ), com o Observatório de Valongo (OV- UFRJ, 2015) são exemplos de instituições nacionais que oferecem graduação e pós-graduação em Astronomia.

Com a LDB de 1996, os tópicos de Astronomia ficaram distribuídos na matéria de Geografia, no Ensino Fundamental,e em Física, no Ensino Médio, conforme os documentos oficiais brasileiros, como os Parâmetros Curriculares Nacionais (PCN+), no tema Universo, Terra e Vida [BRASIL, 2002]

O professor Canniato (CANNIATO, 1974) afirma que as principais razões para introduzir ensino de Astronomia no processo de ensino e aprendizagem nas escolas brasileiras é que esse conteúdo oferece ao educando:

- uma visão geral do desenvolvimento humano em relação ao universo que nos cerca;

- oportunidade de observar o surgimento de modelos para explicar o universo;

- oportunidade de se trabalhar ao ar livre, sem a exigência de materiais custosos ou de um espaço físico laboratorial;

- sentir o prazer estético ligado a ciência (não só contas matemáticas por contas matemáticas), entendendo o universo que nos cerca de forma aplicada.

Levantamentos mais recentes apresentados por Langhi e Nardi (2012) mostram que pesquisadores brasileiros na área de ensino têm publicado justificativas para o 
ensino de Astronomia na educação básica e na formação inicial e continuada dos professores, dentre elas:

- o estudo do universo desperta a curiosidade e a motivação nas pessoas em geral;

- os conteúdos de Astronomia contribuem para uma visão do conhecimento científico, histórico e filosófico;

- a Astronomia expõe o quanto a ciência e a tecnologia não estão distante da sociedade;

- as práticas de observação, assim como a assimilação dos conhecimentos sobre o universo, potencializam o trabalho do docente, uma vez que o tema é bem contextualizado, interdisciplinar e acessível, contribuindo ainda mais para a aprendizagem;

- ensinar Astronomia implica em constantes atividades de observação, seja a olho nu ou através de telescópios - os quais muitas vezes podem ser construídos por alunos e professores;

- o estudo da Astronomia tem um potencial motivador que pode contribuir significativamente para enriquecimento científico;

- a Astronomia possui um bom potencial de divulgação cientifica, por ser altamente atrativa.

Os documentos oficiais da educação no Brasil, (BRASIL, 2002) apontam:

- a prioridade de se conhecer o eixo Terra - Universo - Vida;

- reconhecer a Terra como componente do sistema solar e suas interações;

- entender a evolução do universo e a evolução da vida.

Essas propostas estão distribuídas nas disciplinas de Física, Química e Biologia. Os PCN's mostram a importância de conhecimentos que envolvem a Astronomia e dão oportunidades e possibilidades em incluir esse tema na escola de Ensino Fundamental e Ensino Médio. Embora atualmente o ensino de Astronomia seja pouco abordado nos anos finais do Ensino Fundamental e Ensino Médio, observamos que alguns professores e educadores se preocupam em destacar a Astronomia como parte integrante dos currículos escolares. A proposta de se trabalhar a construção de telescópios no Ensino Médio abre uma janela de possibilidade em abordar o tema de ensino em Astronomia. Como a construção e o entendimento do funcionamento de um telescópio passam pelo 
ensino de Óptica Geométrica, observamos aqui uma excelente oportunidade em abordar a Astronomia com os alunos envolvidos nesse projeto de ensino.

\subsection{0 ensino de Óptica Geométrica}

O tópico de Óptica Geométrica é ensinado nas escolas públicas e na rede particular de ensino na disciplina de Física, geralmente no segundo ano do Ensino Médio. Por se tratar de um tema que envolve aplicações matemáticas, principalmente com geometria, alguns professores se esquivam desse conteúdo, outros por algumas razões comprometem maior parte das aulas do segundo ano do Ensino Médio com esse tema. Mas para os alunos, qual o grau de interesse sobre o tema? Para uma melhor análise da questão do ensino de Óptica Geométrica, é interessante abordar aspectos históricos de como se desenvolveram os conhecimentos nessa área da Física.

\subsubsection{Aspectos históricos da evolução dos conceitos da Óptica}

Várias espécies de animais e entre elas a espécie humana privilegiaram o sentido da visão, dentre os outros sentidos ao longo da sua evolução. O ser humano, como ser consciente, sempre teve curiosidades sobre os fenômenos ópticos, como por exemplo a formação do arco-íris e a variedade de cores, motivando assim uma busca para a explicação da natureza da luz. Walter Santos (Santos, 2010) faz um apanhado interessante sobre a história da lei de refração e das investigações sobre a velocidade da luz, o qual será referencia para todo esse sub-item.

De acordo com o autor, na idade antiga não existem muitos registros de estudos sobre a natureza da luz, sendo que relatos (registrados) mais antigos vêm de Platão e alguns de seus contemporâneos, que observaram os objetos imersos em água parecerem estar "quebrados".

Aristóteles, na sua peça "As nuvens", em 424 a.C. referiu-se à "pedra transparente" o que seria um tipo de lente convergente. Walter Santos cita um trecho da peça:

\footnotetext{
"Strepsiades: você já viu uma bela pedra transparente nos farmacêuticos com a qual se pode ascender fogo?
}

Sócrates: você quer dizer uma lente de cristal?

Strepsiades: Isto! Bem, se eu me colocar com a pedra ao Sol... eu poderia fazer toda cera derreter." 
Euclides (360 a.C. - 295 a.C) registrou os primeiros anúncios do que seria a propagação retilínea da luz e a lei de reflexão, e elaborou alguns axiomas sem definir a natureza dos raios visuais ${ }^{1}$, tais como:

- Raios visuais podem ser desenhados como uma reta ao objeto;

- Os objetos nos quais os raios incidem são vistos;

- Os objetos vistos sob um ângulo maior parecem maiores;

- Objetos vistos por ângulos diferentes têm diferentes intensidade de brilho.

Walter Santos ainda cita Lucrécio (99 a.C. - 55 a.C.), em sua obra De rerum natura, apresenta a teoria de que a luz visível é composta de pequenas partículas, o que seria a primeira ideia de teoria corpuscular da luz:

\begin{abstract}
“(...) a luz e o calor do Sol, são composto de pequenos átomos os quais, quando emanados, não perdem tempo em atravessar o espaço interno de ar em direção imposta pelo emanador"
\end{abstract}

Hierão de Alexandria (10 d.C. - 75 d.C.) afirmou que a luz sempre percorre o menor caminho entre dois pontos (o princípio do que seria a propagação retilínea da luz), e com isso demonstrou que o ângulo de incidência é igual ao ângulo de reflexão. Apesar dessa visão moderna a respeito da luz, Hierão acreditava que a luz emanava dos olhos e refletia com grande velocidade para atingir o objeto a ser observado ${ }^{1}$.

$\mathrm{Na}$ antiguidade, quem se destacou muito foi justamente Cláudio Ptolomeu (90 d.C. - 168 d.C.) com a realização de estudos sobre o fenômeno de refração da luz. Ptolomeu construiu tabelas com diversos valores de ângulos de incidência e refração da luz, o que provavelmente seria os dados experimentais mais antigos já registrados.

Após a queda do Império Romano, a civilização ocidental entrou na "idade das trevas", como muitos historiadores chamam a Idade Média, pois nesse período o progresso científico na Europa estagnou. Porém o desenvolvimento cultural continuou no mundo árabe, o que passou a ser palco da ciência do mundo.

Com Al-Kindi (801 - 873) as publicações na área da Óptica recomeçaram, com o seu trabalho: De Radiis Sterllarum, em que afirmava que todas as coisas do mundo são capazes de emitir raios de luzes em todas as direções e preencher todo o espaço.

1- acreditava-se que a luz emanava dos olhos e atingia o objeto e, assim podia se observar algum corpo. 
Com Alhazen (975-1040) houve um aperfeiçoamento no que seria a "primitiva" lei da reflexão, concluindo que as direções dos raios de incidência e de reflexão estão no mesmo plano normal da superfície. Alhazen também estudou os vários tipos de espelhos esféricos e parabólicos - há quem o considere o pai da Óptica Geométrica. Outra contribuição significativa de Alhazen foi afirmar que a visão acontece quando a luz penetra os olhos e não por emanação de luz do olho, o que se acreditava fortemente nessa época. Entre outros trabalhos de Alhazen, destaca-se o desenvolvimento da câmara escura.

Outros dois árabes deram significantes contribuições e continuidade aos trabalhos de Alhazen - trata-se de Ibn Sina (Avicena) $(980$ - 1037) e Abu Rayhan alBiruni (973 - 1048), conhecidos por seus grandes trabalhos nesse período. Avicena afirmou que “... se a percepção da luz é devido à emissão de alguma partícula por fonte luminosa, a velocidade da luz deve ser finita" [SANTOS, 2010]. Abu Rayhan foi o primeiro a notar que a velocidade da luz é maior que a do som.

No final da Idade Média, a Inglaterra deu um passo a frente, ao romper os laços políticos com a igreja católica e com isso a ciência voltou a ser cultivada na Europa. Roger Bacon (1215 - 1294) é considerado por alguns como o primeiro cientista já no sentido moderno, o qual estudou as combinações de lentes para visualizar objetos a longa distância, tal como o uso dessas lentes nas correções dos problemas de visão. Bacon também conseguiu traçar alguns esquemas de trajetória dos raios de luz ao atravessar uma lente.

Depois de mais de duzentos anos, Giovanni dela Porta (1535 - 1615) na Itália, estudou combinações de lentes e problemas envolvendo vários espelhos na sua obra Magia Naturalis. A partir de então, a evolução da óptica acentuou-se.

Um dos grandes marcos na Óptica foi a invenção do telescópio (Luneta galileana), que embora não tenha uma data bem definida, sua patente foi pedida por Hans Lippershey (1587-1619) um oculista holandês, em 02 de outubro de 1608 na cidade de Haia. Entretanto o nome telescópio se deve a Federico Cesi, que fez a junção de duas palavras de origem grega: tele (longe) e skopeuein (ver). Apesar dos vários trabalhos desses dois estudiosos, o aprimoramento e o uso científico do telescópio se deu na cidade de Pádua, com Galileu Galilei (1564-1642), ao observar a Lua e as quatro principais luas de Júpiter. Logo posteriormente, Johannes Kepler (1571-1630) constrói um telescópio com lente ocular divergente, relatada em seu livro Dioptrice, de 1611. 
Kepler também realizou estudos sobre os efeitos de reflexão interna total entre ângulos pequenos de incidência e refração dentro da óptica.

Contemporâneo ao desenvolvimento do telescópio, e também na Holanda, Zacharias Janssen (1588-1632) constrói o microscópio composto de mais de uma lente, aprimorado por Francisco Fontana (1580-1656), quando propõe a substituição da lente côncava por convexa. Enquanto isso, na Universidade de Leyden, o fenômeno de refração é então descrito de maneira mais completa com Willebrord Snell (1591-1626), detalhando o comportamento da luz ao atravessar a superfície que separa dois meios, na "Lei da Refração", famosa Lei de Snell. Os estudos de Snell, como são conhecidos hoje, foram reformulados por Renè Descartes (1596-1650) em função dos senos dos ângulos de incidência e refração. Descartes considerava a luz como uma transmissão de forma longitudinal da pressão através de um meio elástico, e assim descreve-a na sua obra "La Dioptrique", onde afirma que a luz é um movimento ou ação, intrínseco à matéria, que preenche os espaços vazios entre os corpos de maneira sutil.

No Colégio dos Jesuítas, na França, Francesco Maria Grimald (1618-1663) notou que a luz conseguia contornar os obstáculos, ao observar a sombra de uma haste. Na mesma época, Robert Hooke (1635-1703), em Londres, também observou esse fenômeno. Iniciavam-se ali as pesquisas sobre o fenômeno de difração. Hooke se interessou em investigar a natureza da difração, e em 1665, observou os padrões de interferências através das películas delgadas, o que levou a crer que a luz era movimentos ondulatórios no meio, estabelecendo assim uma base para o que seria posteriormente a teoria ondulatória da luz.

Como não poderia deixar a desejar, Isaac Newton (1642 - 1727) investigou também os fenômenos luminosos. Criterioso em basear-se nos resultados de suas observações direta da natureza, Newton rejeitou a hipótese ondulatória da luz, sendo que uma onda se deslocaria em todas as direções, acreditava então que a luz era composta de corpúsculos luminosos que pulsavam com maior amplitude quando a cor era vermelha e com menor amplitude quando a cor era violeta. A grande contribuição de Newton para a Óptica foi sua investigação sobre a dispersão da luz do Sol através de um prisma, concluindo assim que a luz branca era composta de várias cores diferentes e independentes. Newton publicou seus estudos e conclusões em seu livro Opticks, publicado em quatro edições: 1704, 1717, 1721, 1730, o último corrigido pelo próprio Newton, embora publicado após sua morte [ASSIS, 1998]. 
Na mesma época, Christian Hyugens (1629 - 1695) defendia uma teoria ondulatória, explicando a reflexão, a refração e ainda os fenômenos de polarização, observando a Birrefringência da luz em cristais de calcita. Hyugens em seus estudos conclui que a velocidade da luz diminuía ao passar por meios mais densos.

A velocidade da luz foi medida pela primeira vez por um contemporâneo a Newton e Hyugens, trata-se do dinamarquês Ole Christensen Römer (1644 - 1710). Römer realizou observações a Io, a lua mais próxima a Júpiter, e mediante a essa observação conseguiu determinar que a luz gasta 22 minutos para atravessar a orbita da Terra em torno do Sol, e assim encontrou a velocidade de $2 \times 10^{8} \mathrm{~m} / \mathrm{s}$. Apesar da aprovação de Newton e Hyungens, o resultado de Römer só foi aceito anos mais tarde quando James Bradley (1693 - 1762), com os mesmos métodos, observou a aberração estelar.

A teoria ondulatória da luz veio a se consolidar no início do século XIX com os trabalhos de Thomas Young (1773 - 1829) sobre o princípio da interferência. Poucos anos mais tarde com Augustin Jean Fresnel (1788 - 1827), que unificou os conceitos de Hyugens ao principio da interferência.

Ainda ao longo do século XIX, foram realizados vários experimentos com intuito de medir a velocidade da luz. Em 1849, destaca-se Armand Hippolyte Louis Fizeau (1819 - 1896), que conseguiu pela primeira vez fazer uma medida mais aproximada da velocidade já dentro da Terra. Seu experimento consistia numa roda dentada e um espelho a uma distância de aproximadamente $9.000 \mathrm{~m}$. Com esse experimento, Fizeau conseguiu um valor de $315.000 \mathrm{~m} / \mathrm{s}$.

A teoria corpuscular de Newton tinha poucos seguidores, e em maio de 1850 Bernard Leon Foucault (1819 - 1868) fez um trabalho o qual mostrava que a velocidade da luz na água era menor que no ar. Esse trabalho enfraqueceu ainda mais a formulação Newtoniana.

$\mathrm{Na}$ mesma época, conhecimentos sobre o eletromagnetismo já vinham se desenvolvendo, e com os trabalhos de Michael Faraday (1796 - 1867) estabeleceu-se uma relação entre o magnetismo e a óptica, com a observação de que um feixe luminoso teve alteração no plano de polarização na presença de um forte campo magnético. Mas em 1865, James Clerk Maxwell (1831 - 1879) criou as famosas Equações de Maxwell, unificando todo eletromagnetismo. Ao utilizar as equações, Maxwell demonstrou a velocidade de uma onda eletromagnética, que coincidia aproximadamente com os valores experimentais da velocidade da luz, o que derrubou a teoria corpuscular da luz. 
Em 1888, Heirich Rudolf Hertz (1857 - 1894) conseguiu gerar de maneira experimental as ondas eletromagnéticas, confirmando as previsões de Maxwell.

A vitória da teoria de Hyugens foi momentânea. Em 1905, o jovem cientista Albert Einstein (1879 - 1955) propôs a teoria da relatividade, que derruba o conceito do éter (meio pelo qual a luz, como uma onda se propaga). Einstein reforçou o conceito corpuscular da luz em seu trabalho (o qual lhe rendeu o prêmio Nobel) sobre o efeito fotoelétrico. Mas tarde, a natureza corpuscular da luz foi ainda mais reforçada experimentalmente por Robert Milikan (1868 - 1953), ao realizar medidas do efeito fotoelétrico em 1919, e posteriormente com Arthur H. Compton (1892 - 1962), do espalhamento de fótons por elétrons, conhecido como efeito Compton.

Essas descobertas abriram as portas para o desenvolvimento da óptica quântica (quando a dualidade onda-partícula da luz é assumida) e para o desenvolvimento dos laseres, temas que predominaram as pesquisas em óptica no século XX.

\subsubsection{Aspectos pedagógicos da Óptica Geométrica}

A maioria das aulas de óptica começa de maneira interessante, afinal a visão é uma das principais maneiras do ser humano obter informações do meio externo (caso duvide, tente passar um dia de olhos vendados; para quem não tem esse sentido, a vida não é tão fácil). A luz pode nos trazer varias sensações, nas cores, na intensidade e também a sensação de espaço. Existem crendices populares que afirmam que o amor nasce nos olhos para depois migrar para o coração, o que não é de objetivo neste estudo, mas de notar o quanto valorizamos nossa visão.

Dessa maneira, acreditamos que o estudo da óptica tem o seu potencial de atratividade, o que pode ser notado por professores que atuam no Ensino Médio. O problema está justamente na hora de aplicarmos as leis que regem esses fenômenos, pois envolvem um conhecimento matemático muitas das vezes desestimulante para o estudante - a Geometria, além de diversas leis que se utilizam de entidades físicas e matemáticas muito abstratas, como por exemplo, os raios de luz.

Eric Barros Lopes (2014) mostra em seu estudo algumas razões da dificuldade do ensino de Óptica Geométrica:

- Concepções alternativas adquiridas pelos alunos desde a infância, as quais entram em conflito com o conhecimento científico o qual se deseja transmitir; e 
- Problema da representação gráfica do raio de luz (diagrama dos raios): o estudante tem dificuldade de notar que esse modelo é apenas representativo, e não a realidade propriamente dita.

Algumas concepções alternativas o autor afirma que são obstáculos na aprendizagem de Óptica Geométrica:

- Entidades físicas relacionadas à natureza da luz fora do alcance da percepção humana: velocidade, comprimento de onda, frequência;

- Distorções da luz quando há mudança de meio: o espalhamento da luz na atmosfera é visto como elementar;

- Referencial: o observador é parte do sistema. A localização do observador importante para a análise do fenômeno. O arco-íris, por exemplo, é visto se o observador estiver numa dada posição;

- Linguagem utilizada: expressões cotidianas podem induzir a concepções absurdas do ponto científico, tais como: "árvore que dá sombra”, "ela lançou-lhe um olhar", "seus olhos estão brilhando";

- Explicações espontâneas dos fenômenos, tais como luz parada, raio visual (a luz sai dos olhos).

Romper essas concepções é o objetivo das aulas de óptica no Ensino Médio (e em algumas vezes no ensino superior). Assim, privilegiando o conhecimento científico, trazendo novos conhecimentos e ainda apresentando novos fenômenos aos alunos.

\subsection{Justificativa do projeto}

A peça de Aristóteles, "As nuvens", comentado no sub-item 1.4.1, mostra o interesse do personagem Strepsiades em aplicar "a pedra que ao sol ascende fogo" (lente convergente) em alguma utilidade - derreter a cera.

O que percebemos nas aulas de Óptica Geométrica (assim como todas as aulas de Física) é que boa parte dos conteúdos carecem de aplicações práticas. No Ensino Médio, os alunos geralmente não encontram utilidades na maioria dos conhecimentos envolvidos nos conteúdos apresentados; mesmo que na maior parte das aulas seja explicado o uso desses conhecimentos, ainda assim estão longe da realidade ou do alcance do aluno.

Em vários momentos da história, o homem mostrou interesse em aplicar o conhecimento de Óptica, como citado anteriormente, no desenvolvimento do conhecimento de combinações de lentes, feitos por Roger Bacon para correções de 
problemas de visão; no telescópio refrator, desenvolvido por Hans Lipershey com intuito de realizar observações terrestres, bem como nas melhorias de Galileu Galilei para a utilização de observações astronômicas.

Dessa maneira, acreditamos que o ensino de Óptica Geométrica tem o seu potencial de atratividade quando ligado ao desenvolvimento de equipamentos ou utensílios que possam ser manuseados pelos alunos, a fim de obter um resultado e uma utilização satisfatória. Ou seja, um curso que se tenha como objetivo final a preparação de algo que possa ter utilidade, trazendo assim objetividade nas aulas e aumentando o interesse dos estudantes pelos conteúdos.

Com a construção e montagem da luneta galileana, esperamos que, além de auxiliar o ensino da Óptica Geométrica, os alunos possam realizar observações astronômicas com esse equipamento, abrindo caminhos para iniciar o estudo da Astronomia, como por exemplo, na Bulgária, onde os conteúdos de Astronomia são inseridos na disciplina de Física.

No capítulo 2, abordamos a elaboração da luneta galileana, dos aspectos históricos ao tutorial de montagem do projeto piloto (primeiro protótipo construído) e a versão final (versão posteriormente montada pelos alunos). No capitulo 3, por sua vez, comentaremos sobre a aplicação das aulas, divididas em duas etapas: momento tradicional e momento prático. No capitulo 4, faremos uma análise dos resultados obtidos nas avaliações quantitativas e qualitativas, seguidas de seus respectivos gráficos. E no capitulo 5, para finalizar, faremos as considerações finais e conclusivas deste estudo. 


\section{Capítulo 2}

\section{Elaboração dos instrumentos ópticos}

\subsection{Luneta Galileana}

Luneta galileana é o mais antigo instrumento de observação astronômica usado pelo homem (pelo menos na Europa). Trata-se se um objeto formado por um tubo e duas lentes, cada uma das lentes fixadas em ambas as extremidades do tubo. Uma das lentes é objetiva, que realiza o aumento (ou aproximação) da imagem (lente convergente); a outra é a ocular, que ajusta a imagem ao olho humano (lente divergente).

\subsubsection{Aspectos Históricos}

Diferentemente do que muitos imaginam, a luneta não foi inventada por Galileu Galilei. Na realidade, os árabes começaram a desenvolvê-la por volta do século XIV para fins militares, com base nos estudos de Óptica Geométrica, que eram aplicados a Astronomia por Avicena (980-1037 dC) e Alhazen (965-1039 dC), dentre outros, com influência significativa para estes estudos no final da idade média (VANNUCCHI, 1996).

No ano de 1608, o fabricante de lentes Hans Lippershey teria decidido colocar em uma das extremidades de um tubo de ferro uma lente convergente e na outra extremidade uma lente plana, a qual poderia aumentar o tamanho da imagem dos objetos três vezes mais (SANTOS, 2010). Essa notícia chegou à Itália, e Galileu se interessou em reproduzir essa luneta, e com ela tentar observar as estrelas.

As observações da Lua e de Júpiter realizadas por Galileu ocasionaram na maior quebra de paradigma da história da ciência, com a descoberta das crateras lunares e as quatro principais luas de Júpiter. Até então, as noções de universo advinham das ciências teoréticas de Aristóteles. Para Aristóteles, as leis da natureza eram distintas em dois mundos. O mundo sublunar seria constituído pelos corpos terrestres, com a Terra, imóvel, ocupando seu centro. Constituiria o lugar da mudança e da transformação, da geração e da corrupção e dos movimentos naturais retilíneos, para cima ou para baixo. Já o mundo supralunar ou celeste se referia aos corpos celestes. Nele, nenhuma mudança, transformação, geração ou corrupção podia acontecer, com exceção do movimento circular (POLITO, 2015). Dessa maneira, ao observar crateras na Lua, 
Galileu constatou que o mundo celeste não era tão incorruptível como parecia ser, nem ao menos os movimentos das luas de Júpiter ocorriam entorno da Terra. Esses são exemplos de como a observação de Galileu contribuiu para a desestabilização uma teoria que perdurava quase 20 séculos.

Após Galileu muitos outros, como Kepler, trabalharam no desenvolvimento da luneta, até o telescópio newtoniano com uso de espelhos.

\subsubsection{Lentes esféricas}

As lentes são instrumentos ópticos constituídos de dois meios transparentes, que tem a propriedade de desviar os raios de luz, que sofrem desvio ao atravessar de um meio a outro. A esse fenômeno dá-se o nome de refração.

Há diversos formatos de lentes: plano-côncava, plano-convexas, côncavoconvexa, bicôncava, biconvexa e convexo-côncava; porém na maioria dos casos, as lentes são divididas em dois tipos: convergentes e divergentes.

Podemos representar a formação da imagem de um objeto que está situado no mesmo eixo óptico da lente, com a teoria de formação de imagem através do cruzamento dois raios luminosos. Dessa maneira, podemos utilizar dois raios de luz partindo de um mesmo ponto para deduzir a representação da imagem deste objeto nas lentes convergentes.

No primeiro caso, o objeto posicionado depois do centro de curvatura forma uma imagem real, invertida e reduzida, como no esquema abaixo:

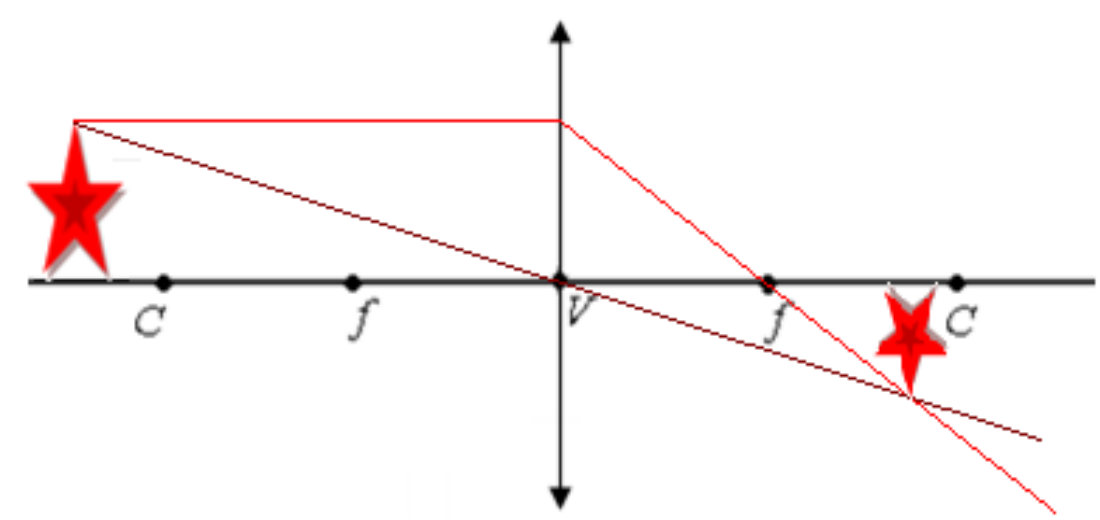

Figura 2.1: representação da imagem obtida numa lente convergente com objeto posicionado depois do centro de curvatura da lente.

No segundo caso, o objeto posicionado no centro de curvatura forma uma imagem real, invertida e de mesmo tamanho, como o esquema abaixo: 


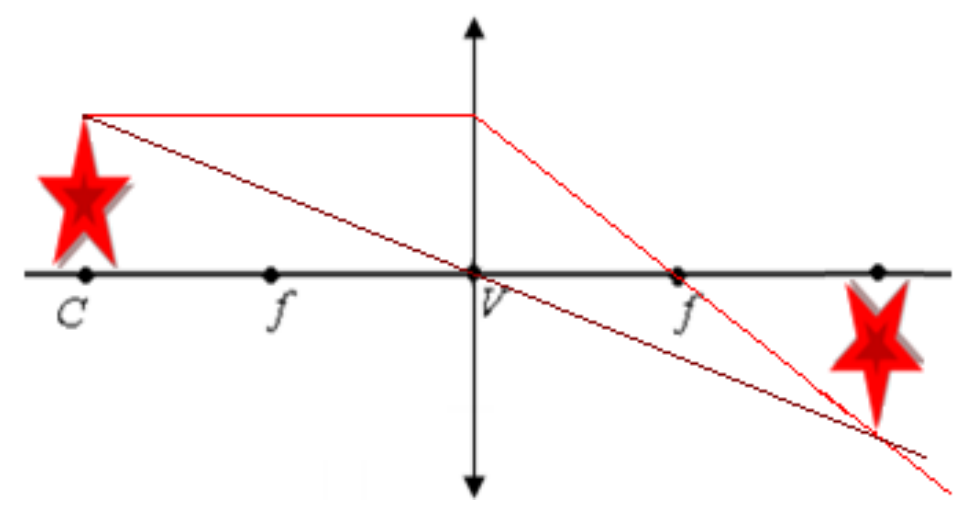

Figura 2.2: representação da imagem obtida numa lente convergente com objeto posicionado no centro de curvatura dessa lente

No terceiro caso, o objeto posicionado entre o centro de curvatura e o foco forma uma imagem real, invertida e ampliada, como o esquema abaixo:

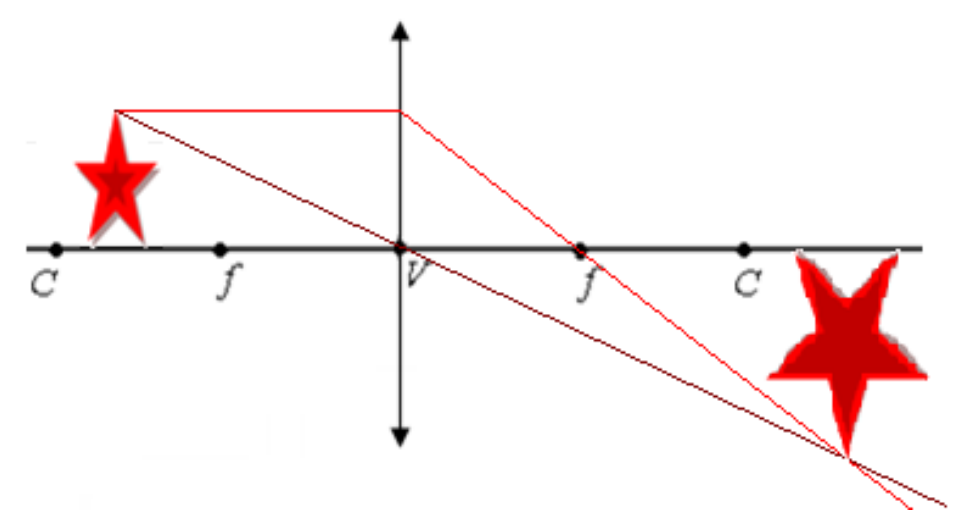

Figura 2.3: representação da imagem obtida numa lente convergente com objeto posicionado entre o centro de curvatura e o foco dessa lente.

No quarto caso, o objeto posicionado no foco da lente forma uma imagem imprópria, pois os raios ao serem refratados na lente são paralelos entre si, e a imagem se forma no infinito, como o esquema abaixo:

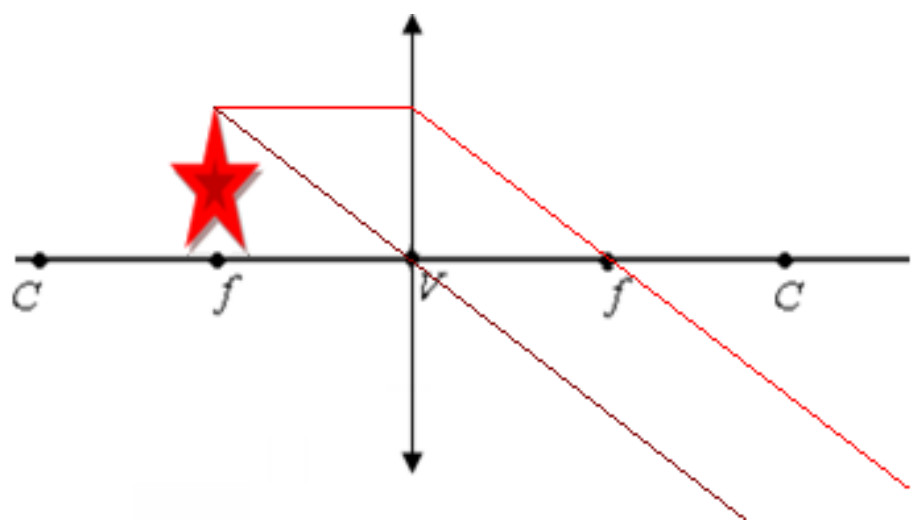

Figura 2.4: representação da imagem obtida numa lente convergente com objeto posicionado no foco dessa lente. 
No quinto caso, o objeto posicionado entre o centro de curvatura e o foco da lente forma uma imagem virtual (formada pelo prolongamento dos raios), direita e ampliada, como o esquema abaixo:

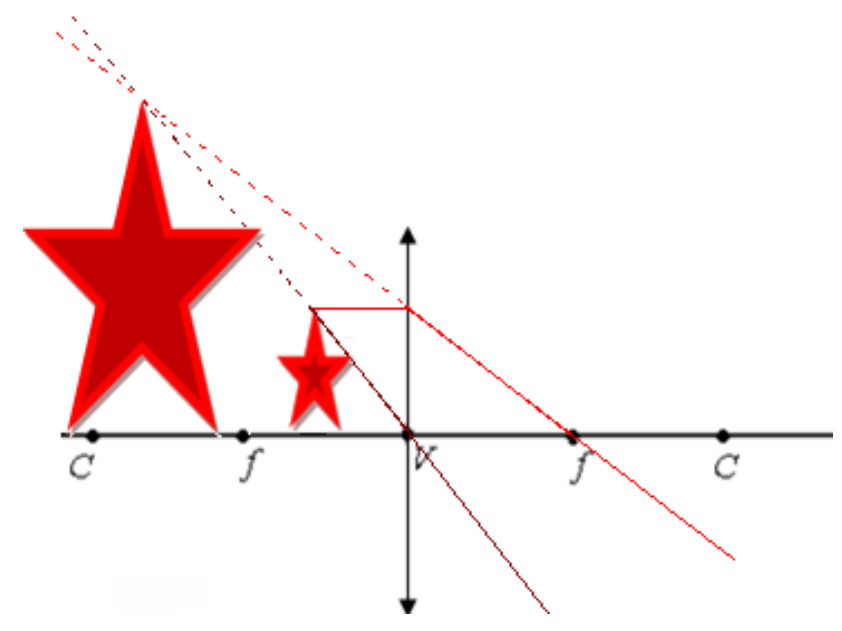

Figura 2.5: representação da imagem obtida numa lente convergente com objeto posicionado antes do foco dessa lente.

Ainda assim, nas lentes divergentes, temos um caso único, onde independentemente da distância entre o objeto e a lente, a imagem sempre será virtual, direita e reduzida, como mostra a figura abaixo:

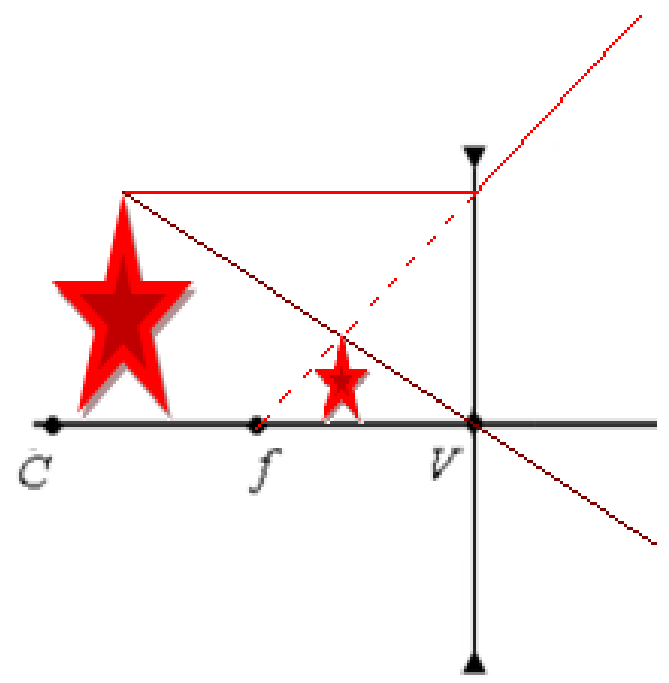

Figura 2.6: representação da imagem numa lente divergente, independente da posição do objeto

Quando utilizamos duas lentes em associação (como é o caso da luneta galileana), obtemos a imagem formada com a mesma analogia do cruzamento dos raios luminosos, agora divididos em dois casos. 
No primeiro caso, podemos associar uma lente convergente e uma lente divergente no instrumento óptico, e a imagem se formará como no esquema a seguir:

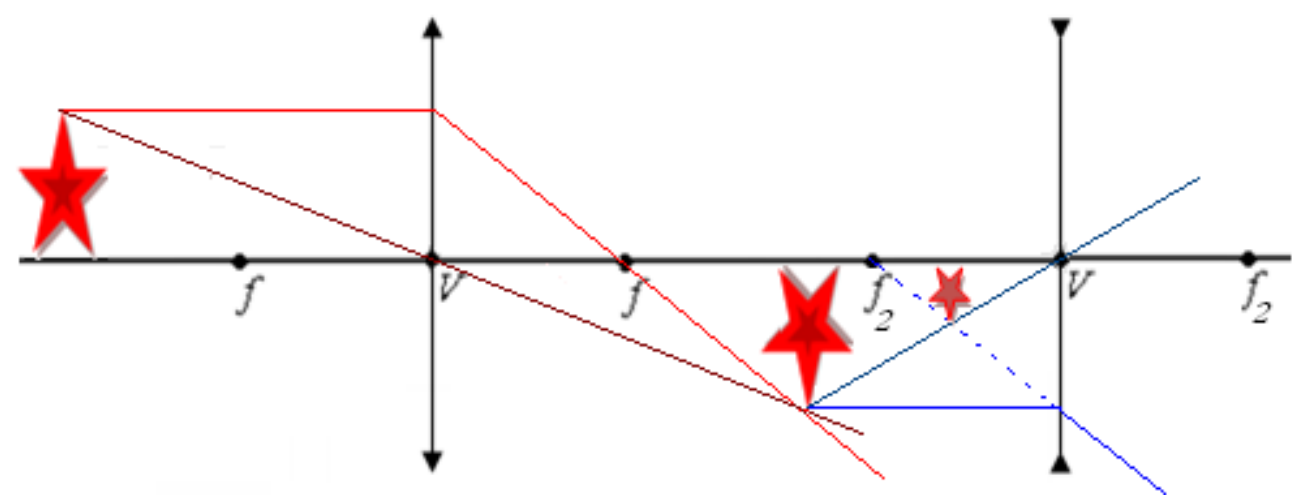

Figura 2.7: representação da imagem numa associação de lentes convergente-divergente.

No segundo caso, associamos duas lentes convergentes no instrumento óptico, como no esquema a seguir:

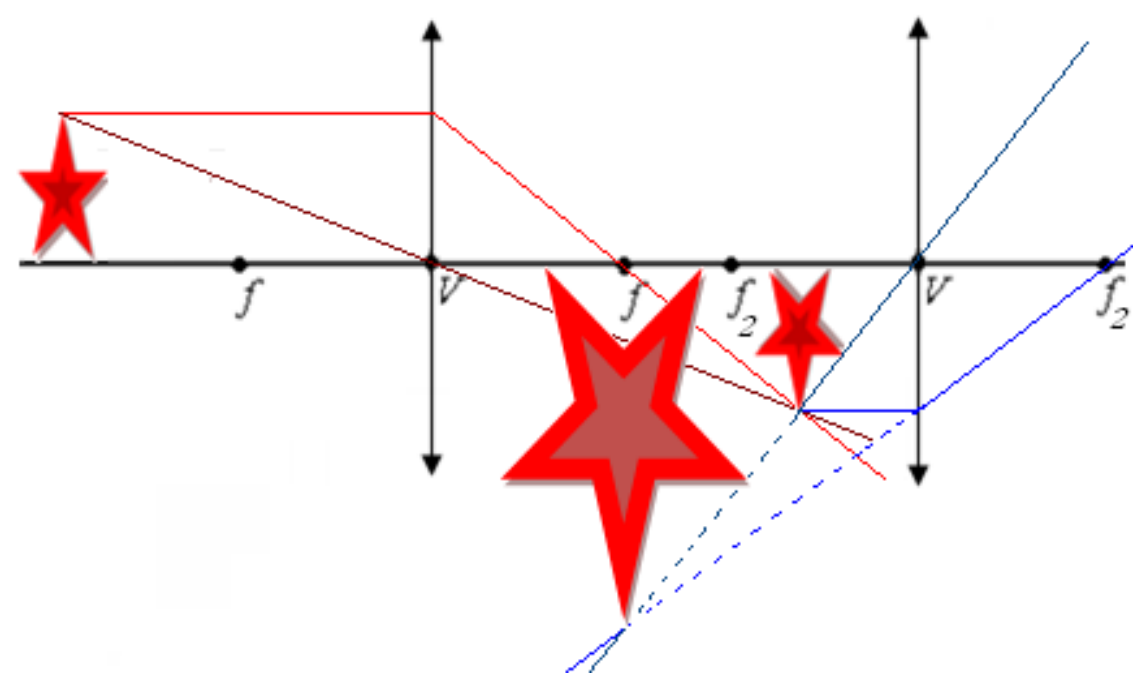

Figura 2.8: representação da imagem numa associação de lentes convergente-convergente.

Nesse último caso, representamos a associação de lentes convergentes utilizada para construir uma luneta, sendo que o objeto está praticamente no infinito (se considerarmos as dimensões das lentes). Com essas informações, é possível dar início a construção de um protótipo inicial de uma luneta, utilizando duas lentes convergentes, ou positivas, como são chamadas as lentes convergentes no jargão comercial.

\subsubsection{Projeto piloto}

O objetivo da utilização de uma luneta é ter um maior poder de alcance visual, assim como uma nitidez plausível, para que possamos fazer observações de objetos à 
longa distância. Como projeto piloto, foi escolhida a princípio uma lente de retroprojetor de transparências, para ser a lente principal da luneta (objetiva), e uma ocular de microscópio para ser a lente secundária (ocular), a qual foi facilmente adquirida em restos de materiais descartados por órgãos público da rede de saúde. De posse dessas duas lentes, o próximo passo foi encontrar o ponto certo de melhor nitidez da imagem, como no esquema a seguir:

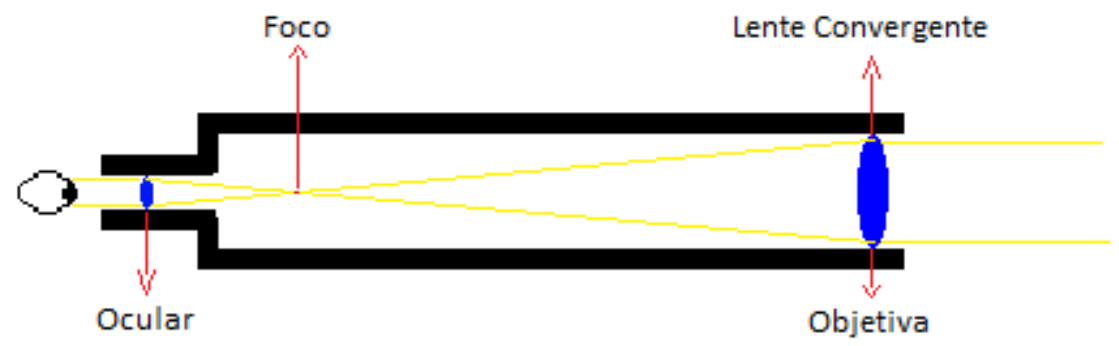

Figura 2.9: Esquema representativo dos raios de luz numa Luneta

Como se pode observar na figura 2.1, o raio de luz sofre refração ao passar pela lente objetiva, formando em seu foco a imagem através do cruzamento dos raios luminosos. A imagem novamente interage com a ocular (que também é uma lente convergente), aliando os raios de luz para formar a imagem no olho do observador, proporcionando assim a impressão de que o objeto está mais aproximado.

Apesar de termos utilizado no projeto piloto uma lente de retroprojetor como objetiva, e uma lente de microscópio como ocular, nada impede a utilização de outras lentes similares (como por exemplos lentes de óculos a qual pode ser encomendada em algumas lojas de ótica), pois o princípio é o mesmo. Ainda assim, outros materiais são necessários:

- Tubo PVC: o comprimento e a espessura são proporcionais ao grau da lente utilizada, e o diâmetro da mesma;

- Conexões: as conexões servem para acomodar as lentes, tanto a objetiva como a ocular:

- Tinta Spray: tanto para acabamento da luneta quanto para a parte interna. Aconselha-se usar a cor preta fosco;

- Serra de aço: para realizar cortes necessários nos tubos;

- Trena: para devidas medições necessárias.

Todos os materiais citados acima podem ser facilmente adquiridos em lojas de materiais de construção, por um preço relativamente baixo, em relação à utilidade que esse equipamento oferece. 
A medida do tubo está diretamente relacionada ao grau da lente objetiva. No caso da luneta em questão, a lente é de um grau e meio (distância focal de aproximadamente $66 \mathrm{~cm}$ ), resultando no tamanho de $60 \mathrm{~cm}$ de tubo. Após cortar o tubo, pinta-se a parte interna do mesmo com a tinta preta fosca, a fim de diminuir a reflexão de imagem.

Após a preparação do tubo, acoplam-se as lentes às conexões (ou reduções, caso a espessura do tubo seja diferente da lente). O ajuste da luneta é feito deslocando as conexões, aumentando ou diminuindo o espaço entre as lentes objetiva e ocular.

Por fim, um equipamento muito útil para a luneta é o tripé. Um tripé de máquina fotográfica é ideal, prático e confortável, e pode ser adquirido em lojas de equipamentos fotográfico, ou ainda em lojas de materiais usados. Para elaboração deste trabalho, foi adquirido um tripé de máquina fotográfica em um "ferro-velho" na cidade do Itapoã no Distrito Federal, por o valor de R\$ 50,00 (U\$16,00 aproximadamente na época).

\subsubsection{Versão final}

A luneta elaborada no item anterior foi construída com intuito de obtermos experiência, para então levar aos alunos uma versão mais aprimorada do modelo. Uma das necessidades que notamos é com relação ao ajuste do foco da luneta - como a primeira luneta tinha apenas um tubo fixo, só conseguiríamos ajustar o foco deslocando muito pouco as conexões, o que nos daria uma mobilidade de no máximo $5 \mathrm{~cm}$ ou $6 \mathrm{~cm}$.

Dessa forma, projetamos uma luneta que pudesse variar mais ainda em tamanho, para que, além de ter mais flexibilidade no ajuste do foco, futuramente possamos também utilizar outras lentes de diferentes focos.

Sendo assim, para essa versão utilizamos:

- Lentes de óculos de +1,25 graus a objetiva e + 4 graus a ocular;

- Tubo de esgoto de $50 \mathrm{~mm}$ com tamanho aproximado de $50 \mathrm{~cm}$;

- Junção de cano de esgoto de $50 \mathrm{~mm}$;

- Tubo de esgoto de $40 \mathrm{~mm}$ com tamanho aproximado de $50 \mathrm{~cm}$;

- Redução de cano de água de 50 mm x 32 mm;

- Cola de cano;

- Fita isolante (ou fita adesiva). 
As lentes são facilmente encomendadas nas lojas de ópticas, por um preço acessível (aproximadamente $\mathrm{R} \$ 50,00$ o par, na época). Os demais materiais também foram encontrados facilmente nas lojas de materiais de construção.

A utilização da redução com medida $50 \mathrm{~mm}$ x 32 é opcional, podendo utilizar a redução de $50 \mathrm{~mm}$ x $20 \mathrm{~mm}$ (por ser mais fácil de encontrar no mercado). Porém, perdese em campo visual, por causa do tamanho da lente. Solicitamos ao técnico óptico o ajuste do tamanho das lentes a serem utilizadas nas lunetas para encaixar facilmente a lente objetiva na junção do cano de esgoto de $(50 \mathrm{~mm})$ e a lente ocular na redução do cano de água (50 mm x $32 \mathrm{~mm})$.

Por serem de 1,25 graus positivo a objetiva e 4,00 graus positivo a ocular, podemos determinar o foco, pois a medida em grau é equivalente ao inverso da medida do foco da lente. Assim, podemos afirmar que a medida do foco da lente de 1,25 graus é de aproximadamente $80 \mathrm{~cm}$, e a lente de 4,00 graus de aproximadamente $25 \mathrm{~cm}$.

Essas informações são importantes, pois assim podermos utilizar os dois tubos de esgoto com $50 \mathrm{~cm}$ cada, e, com mais aproximadamente $10 \mathrm{~cm}$ das conexões, podemos obter uma luneta com tamanho variando entre $0,60 \mathrm{~m}$ e $1,10 \mathrm{~m}$.

É importante que o cano de $40 \mathrm{~mm}$ possa transpassar ajustavelmente pelo tubo de $50 \mathrm{~mm}$, o que trará uma variação maior no tamanho da luneta (para poder focalizar as duas lentes). Para isso, é necessário cortar alguns "anéis" de tubo de $40 \mathrm{~mm}$, deixando separado, conforme a figura 2.2 abaixo:
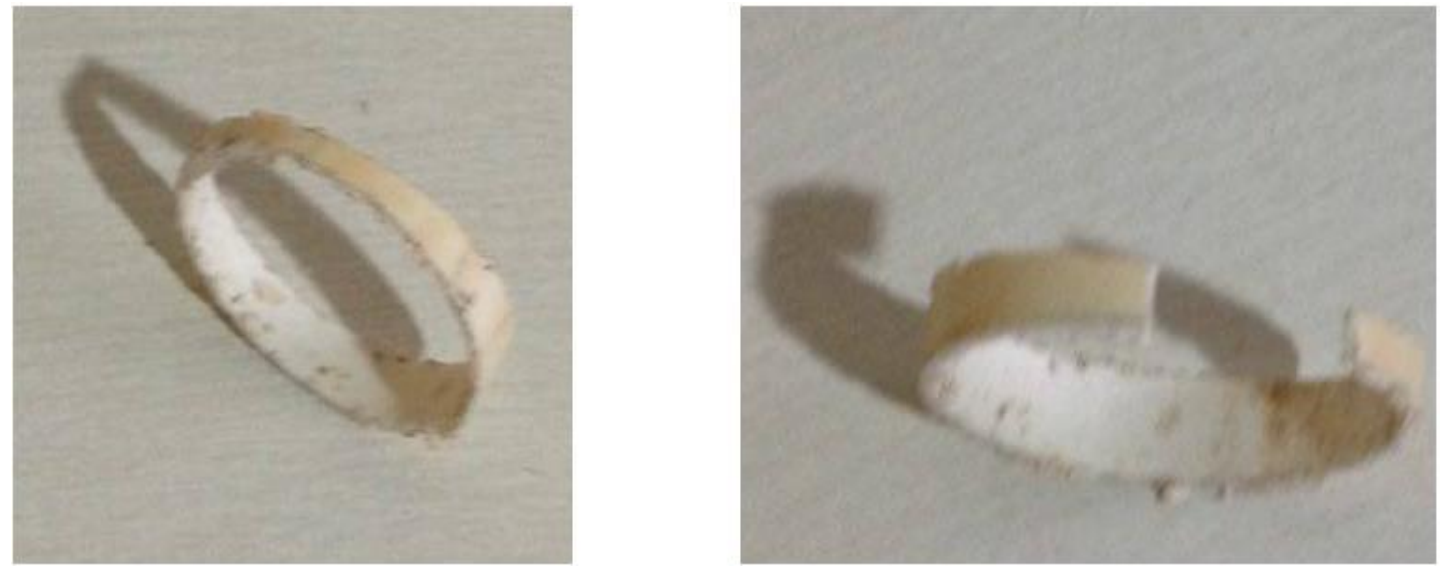

Figura 2.10: ̀̀ esquerda, foto de um anel de tubo de $40 \mathrm{~mm}$; à direta, foto do anel cortado.

Os anéis servem justamente para que o cano de $40 \mathrm{~mm}$ passe pelo cano de 50 $\mathrm{mm}$, sem folga, evitando assim que as lentes fiquem desalinhadas (as lentes não fiquem 
no mesmo eixo óptico). Para isso, é preciso colar dois anéis no cano de $40 \mathrm{~mm}$, um em cima do outro, de preferência um par em uma extremidade do tubo e o outro par na metade do tubo. Na Figura 2.3 é possível notar como fazer essa colagem.

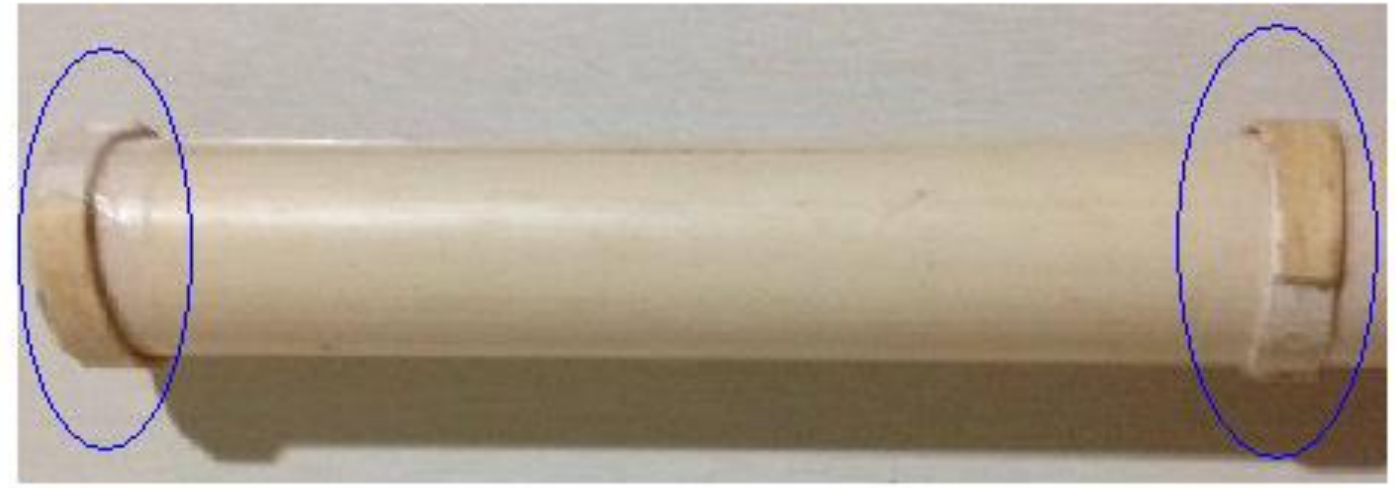

Figura 2.11: Colagem dos anéis cortados no tubo de $40 \mathrm{~mm}$. Tanto na extremidade (à esquerda) quanto no meio do tubo (à direita) cola-se um anel cortado e depois outro anel cortado por cima.

Dessa maneira, os anéis permitem que o tubo de $40 \mathrm{~mm}$ deslize facilmente por dentro do tubo de $50 \mathrm{~mm}$. Porém, caso ainda haja mais alguma folga (que tire as lentes do mesmo eixo óptico), recomenda-se passar uma fita isolante por cima dos anéis, o que ajuda a melhorar o ajuste. Na Figura 2.4 é possível observar como colocar a fita isolante.

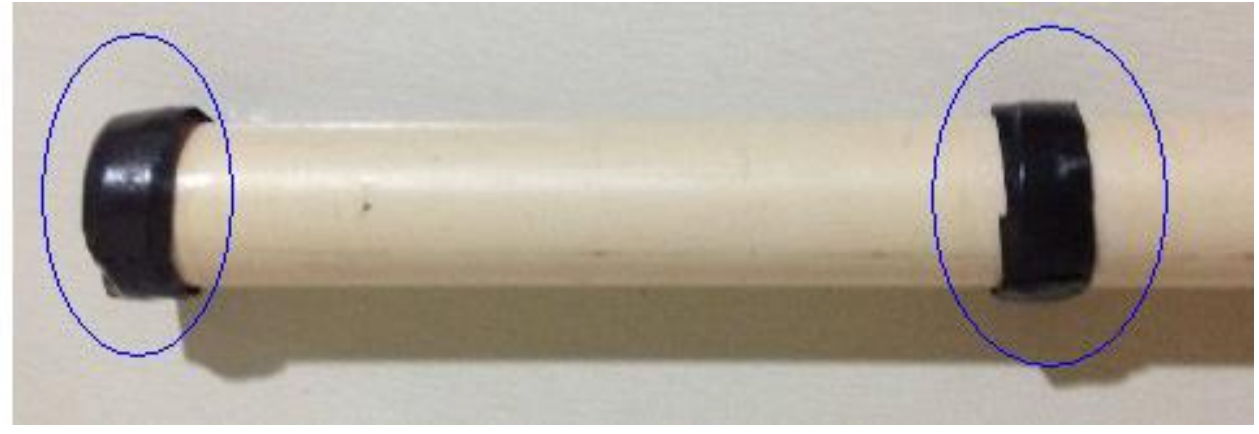

Figura 2.12: Fita isolante para melhor ajuste entre os dois tubos.

Com os dois canos já preparados, resta agora acoplar as lentes. A lente objetiva é colocada entre a junção de $50 \mathrm{~mm}$ e o tubo de $50 \mathrm{~mm}$, de modo a fixá-la quando o tubo adentrar a junção, conforme a Figura 2.5. 


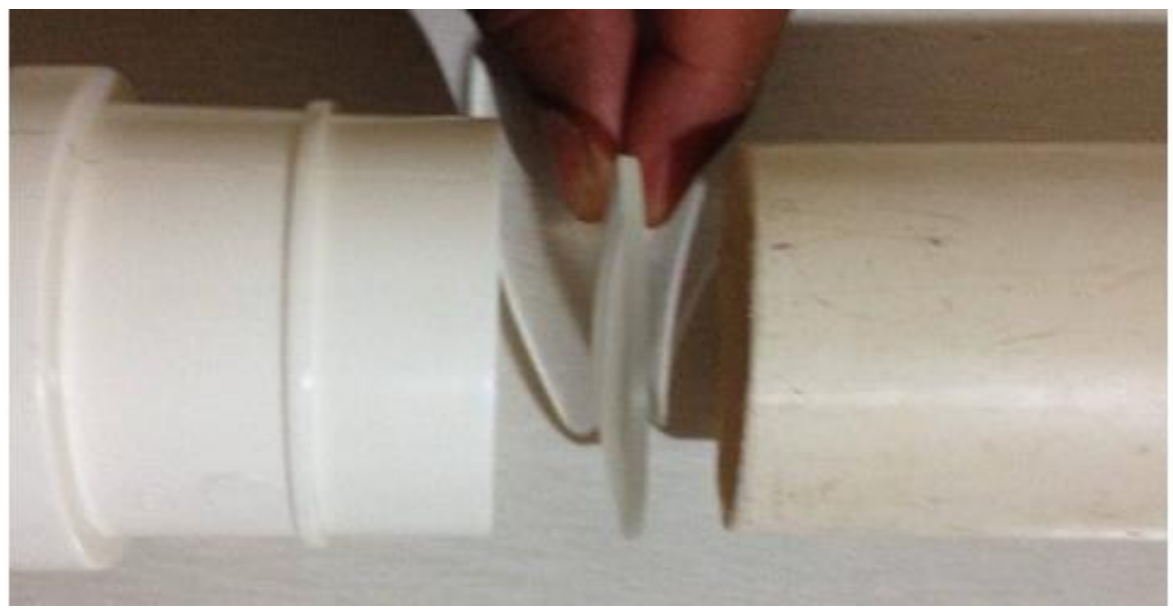

Figura 2.13: Acoplagem da lente objetiva ao tubo de $50 \mathrm{~mm}$.

Já a lente ocular será encaixada diretamente na redução de $50 \mathrm{~mm}$ x $32 \mathrm{~mm}$, isso por que a lente ocular é pequena, e consequentemente fácil de sumir em uma observação. Por essa razão, recomenda-se deixar a lente sempre acoplada à redução de $50 \mathrm{~mm}$ x $32 \mathrm{~mm}$ e de maneira firme. Na Figura 2.6 é possível visualizar a lente e a redução de $50 \mathrm{~mm}$ x $32 \mathrm{~mm}$.

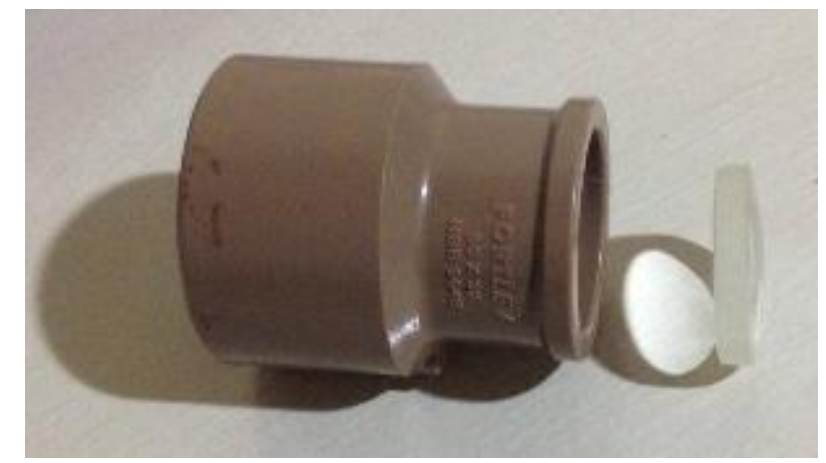

Figura 2.14: Acoplagem da lente ocular na redução de $50 \mathrm{~mm} \times 32 \mathrm{~mm}$

A próxima etapa é encaixar a redução $50 \mathrm{~mm}$ x $32 \mathrm{~mm}$ no tubo de $40 \mathrm{~mm}$. A redução é para encaixar num tubo de $50 \mathrm{~mm}$ de água; porém, neste caso, encaixamos num tubo de $40 \mathrm{~mm}$ de esgoto, que é ligeiramente mais delgado. Por essa razão, mais uma vez cortam-se os anéis de tubo de $40 \mathrm{~mm}$ e separa-os conforme a Figura 2.2, mas, ao invés de colocarmos um anel em cima do outro, vamos colar um ao lado do outro na outra extremidade do tubo (por que os tubos de água são ligeiramente mais finos que os tubos de esgoto), e se o encaixe não for perfeito, mais uma vez iremos passar fita isolante sobre os anéis, até o encaixe ficar justo. A Figura 2.7 permite observar a 
sequência de como fazer o encaixe da redução $50 \mathrm{~mm}$ x $32 \mathrm{~mm}$, finalizando a montagem do tubo de $40 \mathrm{~mm}$ onde fica a lente ocular.
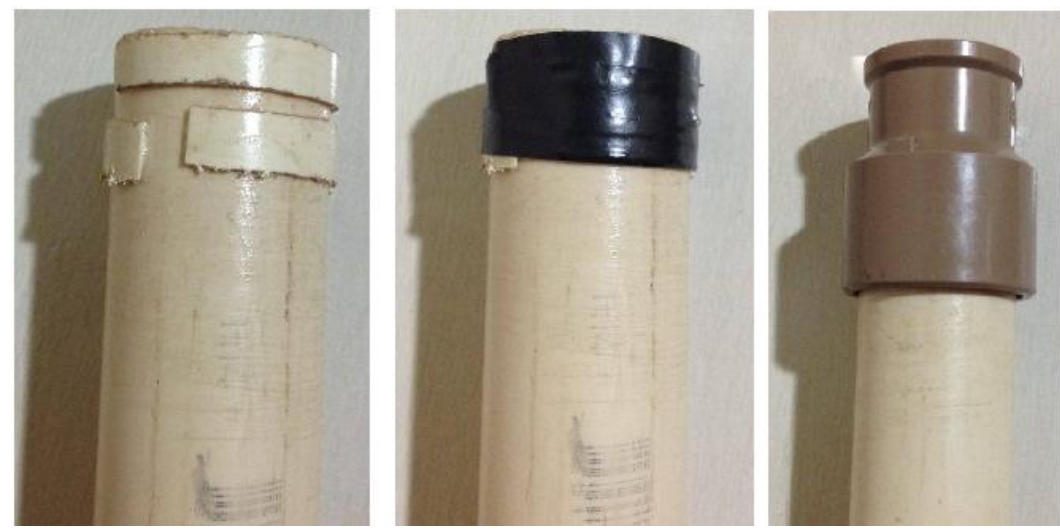

Figura 2.15: Montagem final do tubo de $40 \mathrm{~mm}$.

Por fim, basta encaixar o tubo de $40 \mathrm{~mm}$ (parte da luneta com a lente ocular) no tubo 50 (parte da luneta com a lente objetiva), finalizando a montagem da luneta. A Figura 2.8 apresenta a luneta montada.
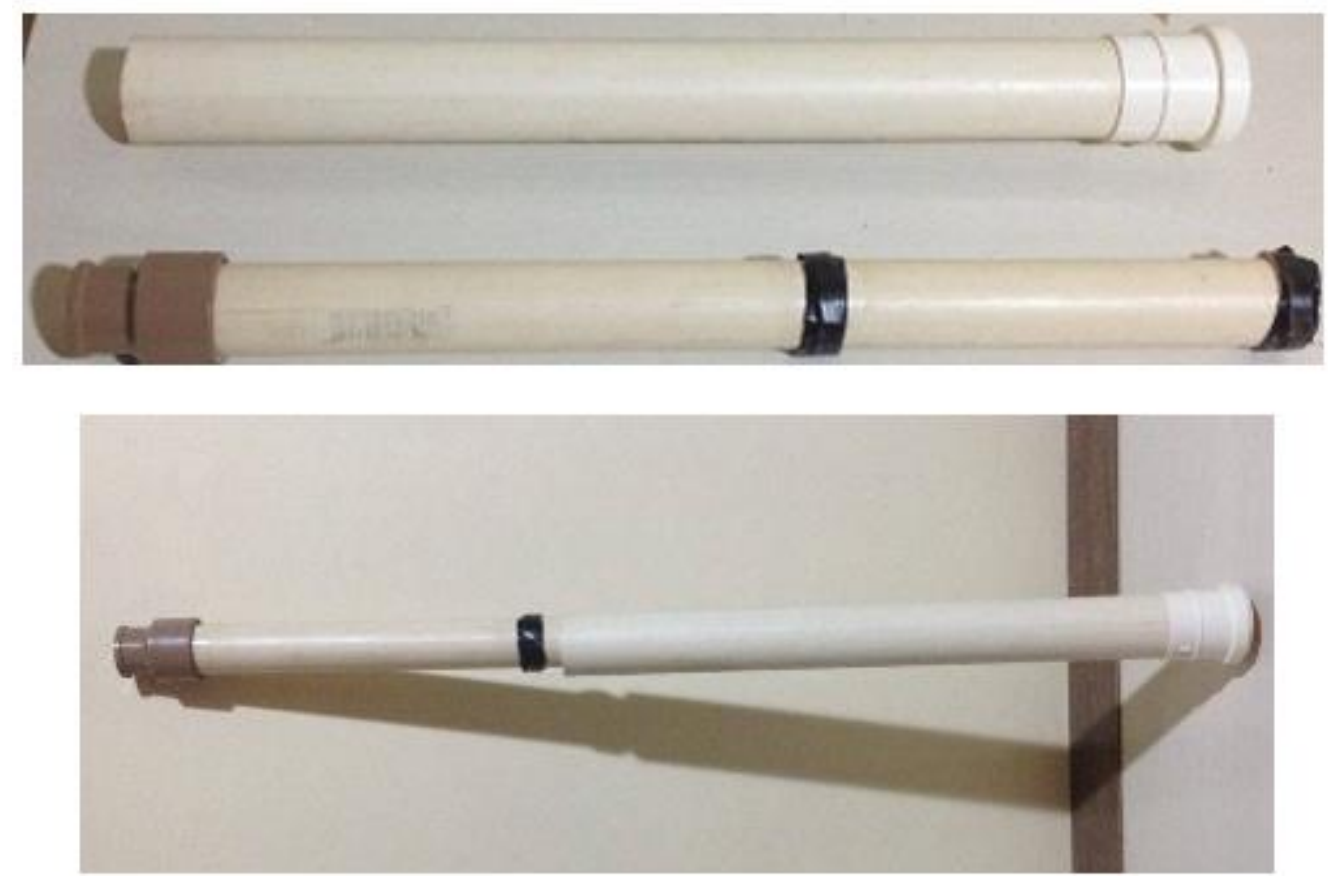

Figura 2.16: Luneta montada.

É importante pintar a luneta, de preferência com tinta spray da cor "preto fosco". Primeiro na parte de fora, por razões estéticas, e principalmente por dentro dos tubos, para evitar reflexos de imagens nas paredes internas dos canos. 


\section{Capítulo 3}

\section{Aplicação em sala de aula}

A aplicação deste trabalho foi realizada em uma escola da zona urbana do Paranoá, no Distrito Federal, em duas turmas de $2^{\circ}$ ano do Ensino Médio, do período noturno. Os principais desafios para a aplicação deste trabalho levantam algumas questões que devem ser analisadas:

- A construção e montagem de uma luneta galileana têm potencial de facilitar a aprendizagem da Óptica Geométrica?

- Ensinar a construir equipamentos de óptica, como a luneta, terá um poder atrativo de aguçar a curiosidade dos alunos?

- Os alunos ficarão mais interessados nos conteúdos de Física?

- A aprendizagem será satisfatória?

Essas questões motivaram esse projeto e, ao final desta aplicação (a construção da luneta), verificamos que o modo como foram dadas as aulas foi realmente eficaz. Além disso, observamos que houve melhorias no aprendizado e consequentemente nas notas das avaliações realizadas pelos alunos.

Para esse trabalho, as aulas foram desenvolvidas em duas etapas, as quais nomeamos de Cenário tradicional e Cenário prático (focado na montagem da luneta):

\section{$\rightarrow$ Cenário tradicional}

- Professor fala e o aluno passivo só presta atenção, copia o conteúdo e observa o professor regendo a aula;

- os conteúdo desenvolvidos abordaram: propriedades e natureza da luz, reflexão da luz e espelhos planos e esféricos;

- exercícios que basicamente envolve cálculos aritméticos;

- testes tradicionais com questões parecidas com os exercícios resolvidos em sala de aula (ver Apêndice A e Apêndice B).

\section{$\rightarrow$ Cenário prático}

- Os alunos são ativos - manipulam os equipamentos e fazem observação direta dos fenômenos;

- conteúdo de refração da luz, lentes planas e esféricas e instrumentos ópticos;

- exercícios e atividades direcionadas à construção do equipamento; 
- avaliação com um texto dissertativo (redação), a montagem da luneta e uma prova;

Encontra-se aqui uma oportunidade de realizar uma comparação entre as duas etapas de aprendizagem, e analisar em qual etapa os alunos tiveram mais sucesso na aprendizagem.

\subsection{Cenário tradicional}

Na primeira aula, foi exposta a introdução da Óptica Geométrica. Utilizamos o livro didático Física: Termologia, óptica, ondulatória, $2^{\circ}$ ano -2 . Ed, dos autores Bonjorno, Clinton, Prado e Cassemiro (2013).

A primeira aula teve duração de 1 hora e 30 minutos (aula dupla), na qual foi abordada a natureza da luz como uma onda, e a sua trajetória retilínea, a independência dos raios de luz e a reversibilidade dos raios de luz. Foram comentados os fenômenos de eclipse do Sol e da Lua (eclipse total e parcial), por formarem sombra e penumbra.

A segunda aula teve duração de 45 minutos (aula simples), em que foi abordada a diversidade de cores da luz relacionada à frequência e/ou comprimento de onda; abordamos as cores primárias da luz: azul, vermelho e verde e a combinação dessas cores que formam cores secundárias; abordamos a composição das luzes policromáticas a partir das luzes monocromáticas. Ainda nesse mesmo tópico, falou-se das cores dos corpos (a luz recebida e a luz refletida pelos corpos), assim como os tipos de fontes luminosas.

Na terceira aula (aula simples) foi passado questionários e exercícios de fixação, o qual exigia dos alunos uma revisão dos assuntos já trabalhados, ou uma simples leitura do tema no livro texto (BONJORNO, 2013). Questões envolvendo a incidência de luzes num corpo, assim como exercícios para desenhar trajetórias da luz. Na mesma aula, a atividade foi respondida pelos alunos e corrigida pelo professor. Algumas questões foram sobre a câmara escura, onde foi abordado o princípio da máquina fotográfica. Após estas três primeiras aulas, foi aplicado o Teste 1 (ver Apêndice A), sobre os assuntos envolvidos na primeira e segunda aula.

Na quarta aula (aula simples) foi trabalhado o conteúdo de reflexão da luz; as leis de reflexão e a formação de imagens num espelho plano, os conceitos de imagem real e virtual, e campo visual. Foram passados exercícios e questionários do livro texto. 
$\mathrm{Na}$ quinta aula (aula simples) foram resolvidos os exercícios passados na aula anterior. No final da aula foi feita uma abordagem sobre a associação de espelhos planos.

Na sexta aula (aula dupla) foi iniciado o tema de espelhos esféricos. Neste tema, foram abordados os elementos geométricos dos espelhos esféricos, como centro de curvatura, raio de curvatura, vértice, eixo principal e foco, bem como a formação de imagens nos espelhos esféricos.

Na sétima e oitava aula (aula simples e aula dupla), os alunos realizaram os exercícios sobre a formação das imagens no espelho esféricos, onde foram auxiliados individualmente na resolução dos exercícios. No final destas duas aulas, fizemos a correção dos exercícios.

Finalmente, foi realizada a segunda avaliação - Teste 2 (ver Apêndice B), abordando os assuntos de espelhos esféricos, construção e tipos de imagens formadas nos espelhos esféricos.

\subsection{Cenário prático}

Nessa etapa da aplicação, foi trabalhado o conteúdo de refração da luz e lentes, planas e esféricas. As aulas foram práticas, onde os alunos manipularam as lentes e observaram suas propriedades, fizeram medidas de distâncias focais e ao final dessas atividades montaram as lunetas.

\subsubsection{Primeira aula}

Na primeira aula dessa etapa (aula dupla), foi apresentado e desmontado o telescópio refletor, constituído por dois espelhos (espelho principal - esférico - e espelho secundário - plano) e a lente ocular (convergente). Em uma representação gráfica na lousa, foi demonstrado como os raios de luz incidem paralelamente no espelho principal (pois se admite que os raios venham do infinito) e convergem para o espelho secundário (espelho plano), o qual desvia esses raios para lente ocular, que tem o papel de ampliar a imagem. Na etapa do Cenário Tradicional, foi abordada a teoria dos espelhos esféricos, conceito de foco, centro e curvatura, vértice e representação gráfica dos raios de luz; nessa aula prática, tivemos a oportunidade de trabalhar esses conceitos com o espelho esférico do telescópio, medindo foco e raio de curvatura com uma trena. Os alunos tiveram a oportunidade de observar objetos ampliados refletidos 
pelo espelho nas posições entre o foco e o vértice e também imagens invertidas reduzidas ou ampliadas, à medida que se distanciavam do espelho esférico. Após essa explicação, montamos novamente o telescópio, e os alunos tiveram a oportunidade de visualizar através deste instrumento algumas imagens fora da escola, pela janela da sala de aula.

Após o estudo prático sobre telescópio refletor, apresentamos aos alunos três lunetas galileanas (telescópios refratores), instrumentos de observação compostos de duas lentes: ocular e a objetiva. Da mesma forma, desmontamos as lunetas para uma aula prática sobre lentes e cada aluno manipulou e observou essas lentes. Uma dessas lunetas era o modelo da luneta que os alunos construíram ao final dessa etapa prática.

Durante essa aula, para a explicação do fenômeno de refração da luz, utilizamos uma caixa de plástico retangular transparente com água e um laser verde para demonstrar como um raio luz "quebra o seu caminho" ao mudar de um meio refrator para outro, como pode ser visto na Figura 3.1.

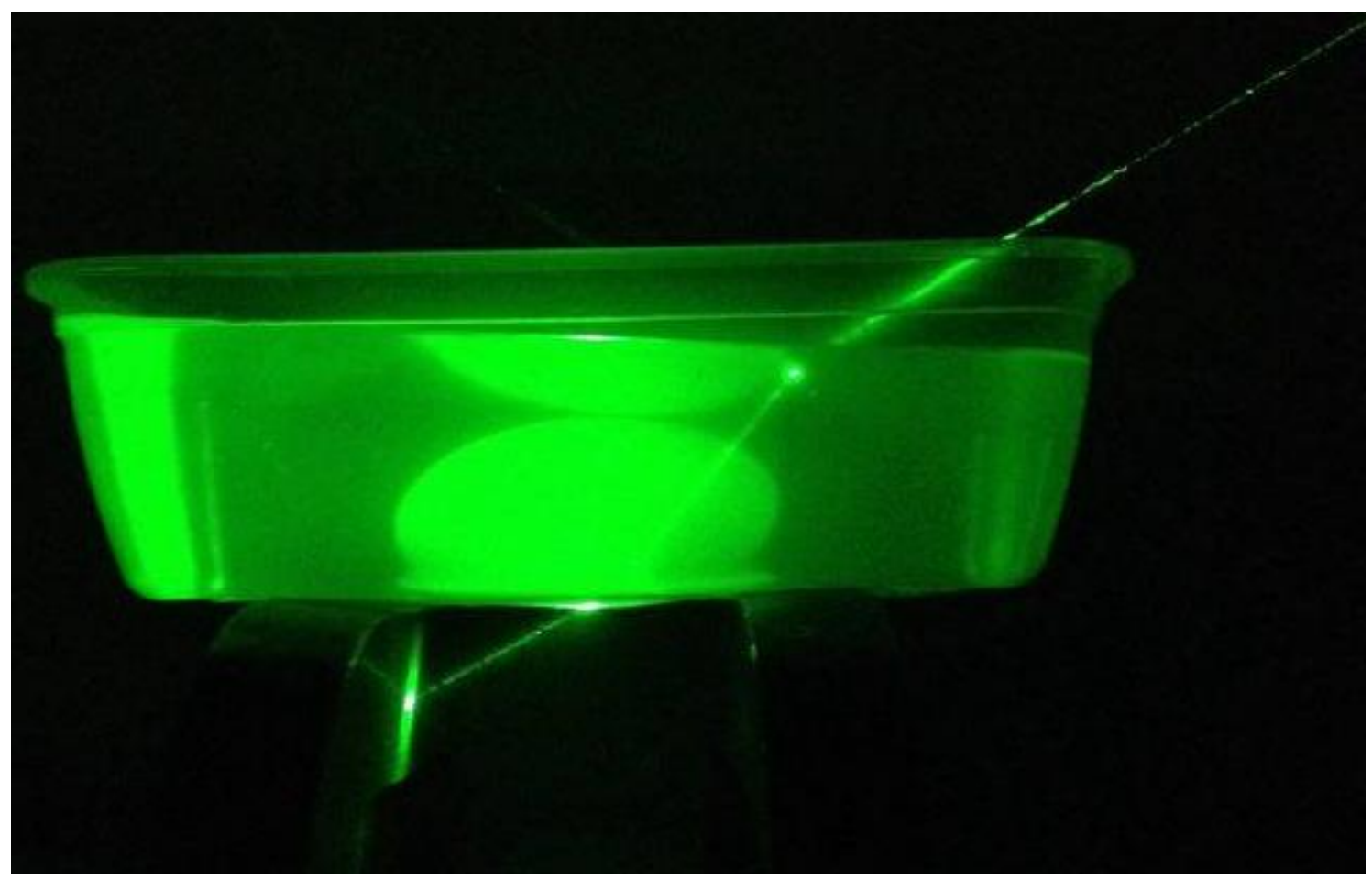

Figura 3.1: Experimento de refração realizado em sala de aula (utilizamos um spray, para realçar a visualização do laser).

Em uma de nossas lunetas tínhamos um prisma diagonal - prisma de $45^{\circ}$ (Prisma de Porro). Esse prisma tem a propriedade de desviar raios de luz em ângulos de 
90, conforme mostra a Figura 3.2. Dessa maneira, explicamos aos alunos o fenômeno da reflexão interna total da luz em meios refratários.

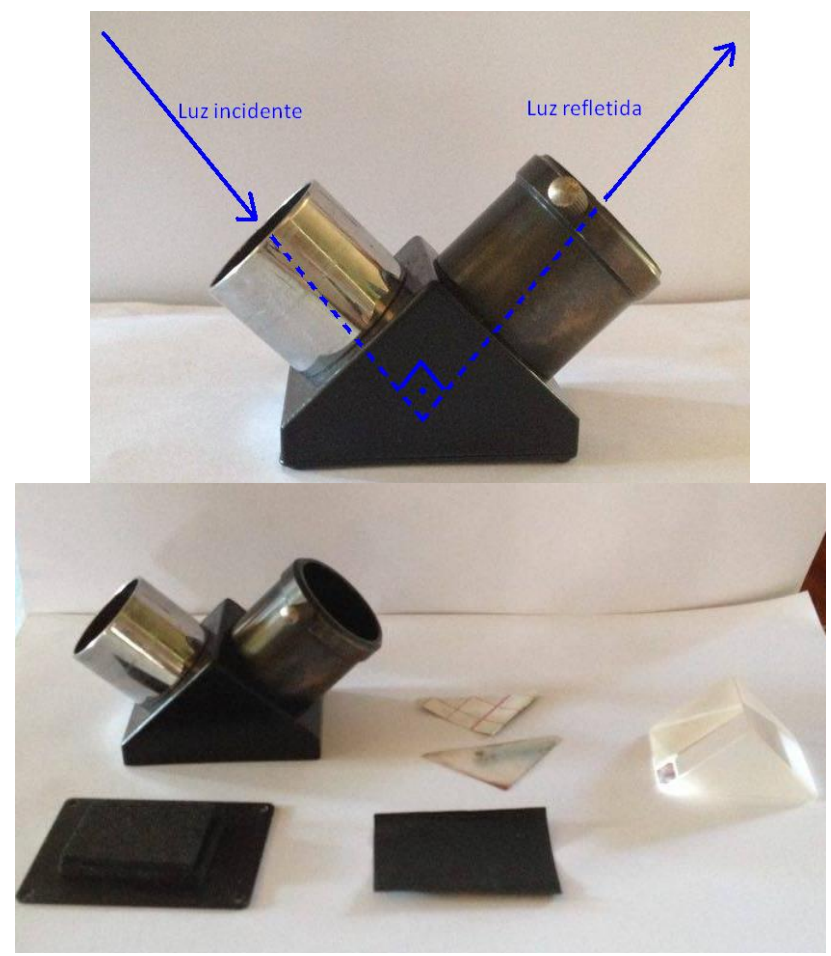

Figura 3.2: Prisma diagonal da luneta e as peças que a compõem.

Explicamos aos alunos a propriedade que o prisma tem de refratar diferentes comprimentos de ondas em diferentes ângulos. Então, demonstramos na prática o fenômeno de decomposição da luz branca no seu espectro de cores, como mostra a Figura 3.3.

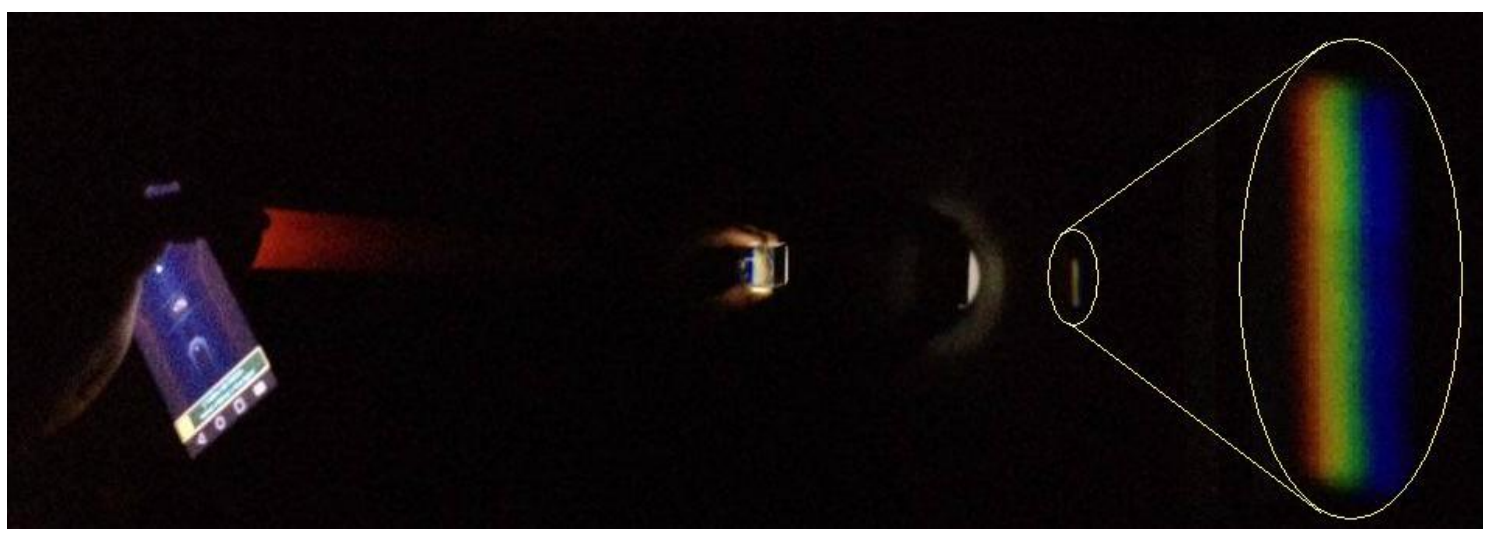

Figura 3.3: Ao incidir a luz de uma lanterna de celular num prisma, há a decomposição da luz.

Para o tópico seguinte dessa aula, utilizamos as lentes das lunetas para explicar suas propriedades e a forma com que elas são utilizadas como instrumentos ópticos. 
Utilizando a iluminação ambiente da sala de aula, foi possível observar a formação de imagem da lâmpada fluorescente no chão, através da lente objetiva da luneta. Do mesmo modo, projetamos a imagem da tela do celular.

Através dessas observações foi possível explicar que os raios de luz vindos de uma distância consideravelmente grande (em relação ao tamanho da lente) convergem para o foco da lente. A partir dessas demonstrações, explicamos aos alunos que uma lente é constituída de centro de curvatura, foco, vértice e espessura. Então, os alunos foram orientados a observar objetos através das lentes, para perceberem mudanças de tamanho, nitidez e orientação dos objetos observados.

Foram expostos também aos alunos os diversos formatos de lentes e suas respectivas figuras representativas: plano-côncava, plano-convexas, côncavo-convexa, bicôncava, biconvexa e convexo-côncava. Os alunos observaram novamente as lentes da luneta a ser montada por eles, e constataram que as duas lentes eram côncavoconvexas. Foi explicado também aos alunos que nos seis formatos das lentes observamse os fenômenos de convergência e divergência dos raios de luz, dividindo assim as lentes em dois tipos: convergentes e divergentes.

\subsubsection{Segunda aula}

Na segunda aula (aula simples), foi apresentada uma luneta para os alunos e em seguida desmontada para apresentar as lentes aos mesmos. Mostramos que as duas lentes da luneta, objetiva e ocular, são lentes do tipo convergentes. Foi reforçado e reafirmado que a lente é um instrumento óptico de aplicação das propriedades de refração da luz. Essa propriedade permite que os raios de luz mudem a trajetória de modo a convergirem em um ponto focal.

Foi permitido aos alunos manipularem as lentes e em seguida montamos a luneta. Os alunos perceberam que ao observar objetos pela luneta, a imagem fica invertida e ampliada. Então foi explicado esse fenômeno com a representação dos raios de luz e a construção geométrica das imagens. Abordamos novamente a Lei de Gauss na lousa, conectando o conteúdo teórico com o recente aprendizado prático com as lentes da luneta. Ao final da aula, resolvemos um exercício de aplicação da lei de Gauss e da formação de imagens numa lente convergente e entregamos aos alunos a lista de exercícios de preparação para a prova (ver Apêndice C). 


\subsubsection{Terceira aula}

Nessa aula (aula simples) foi corrigida a lista de exercícios (Apêndice C) com os alunos. Na primeira questão, foi explicado o fenômeno de refração através da experiência do lápis dentro de um copo com água. Os conceitos de refração da luz foram reforçados. Pode-se dizer que o efeito de "quebra do lápis" é visualizado por que a luz muda de direção de propagação ao mudar de meio. Notou-se que os alunos sabem definir refração, mas não estão familiarizados ao fenômeno, visto que não conseguiam perceber que o lápis quebrado é um efeito visual da refração da luz. Por essa razão, repetiu-se a experiência da caixa de plástico retangular transparente contendo água e o laser, e ainda foi emerso o lápis na água e visto o fenômeno presencialmente.

$\mathrm{Na}$ questão 2, os alunos teriam que definir o tipo de lente segundo o formato, os quais tiveram mais facilidade (bastava olhar no caderno o conteúdo copiado da lousa e associar ao desenho da questão). Apesar da facilidade, algumas vezes confundiam côncavo com convexo. Foi preciso reaver a explanação, e exemplificar com uma colher: o local onde se coloca o alimento é a parte côncava da colher, logo as costas dessa colher é a sua parte convexa. Foi também citado o Congresso Nacional em Brasília, capital do Brasil: a Câmara dos Deputados tem o formato côncavo, enquanto o Senado Federal tem o formato convexo.

Na questão 3, todos teriam que usar a lei de Gauss para encontrar a distância entre a imagem formada e a lente. $O$ primeiro passo seria interpretar a informação de que se os raios solares convergem a $10 \mathrm{~cm}$ de distância da lente, então o foco da lente é de 10 $\mathrm{cm}$. Os alunos tiveram dificuldade em interpretar que os raios solares incidindo na lente se agrupam no foco, mas compreenderam posteriormente pelo fato de que todos os raios chegam aproximadamente em paralelo, pois em relação ao tamanho da lente a distância ao Sol é considerada infinita, sendo assim se direcionam para o foco. Com a informação do foco da lente obtido por essa interpretação e o dado de um segundo objeto a $20 \mathrm{~cm}$ da lente, pode-se obter a distância da imagem utilizando a lei de Gauss, e assim foi corrigida a questão. Aproveitou-se para reforçar o conceito de que a luz vinda do infinito, por exemplo, de planetas, lua e estrelas, etc. é convergida ao foco, explicação que foi extremamente útil para confecção da luneta.

Na questão 4, o aluno teria que saber que o aumento é dado pela razão da altura da imagem pela altura do objeto. Com essa informação, através da proporcionalidade entre altura do objeto e altura da imagem com distância do objeto e distância da imagem, é 
possível combinar essa equação com uma equação obtida da lei de Gauss e chegar ao valor da distância do objeto, e consequentemente à distância da imagem. Ao se calcular a diferença entre a distância da imagem e a distância do objeto, encontra-se a distância entre o objeto e a imagem. Como o problema tinha quatro etapas, os alunos sentiram muita dificuldade, isso por que a extensão do problema causa confusão no raciocínio dos estudantes, e consequentemente o desânimo na hora de resolver.

$\mathrm{Na}$ questão 5, os alunos teriam que responder a 2 perguntas: distância entre o objeto e a lente e o aumento dessa lente. $\mathrm{O}$ cálculo da distância foi realizado facilmente pelos alunos (provavelmente de maneira mecânica), que seria aplicar a lei de Gauss. Já na segunda pergunta, os alunos tiveram que aplicar o aumento como sendo a razão entre a distância da imagem e a distância do objeto.

Toda a resolução da lista de exercício é possível visualizar no produto educacional (ver Apêndice E).

\subsubsection{Quarta aula}

A quarta aula (aula dupla) foi a mais importante de toda aplicação, pois foi o momento de realizar a construção da luneta galileana. Foi apresentada novamente a luneta e mais uma vez foi explicado de forma expositiva que este equipamento óptico consiste em uma associação de lentes. Foi desenhado na lousa como funciona a associação de lentes na luneta astronômica, como pode ser visto na Figura 3.4, e com isso o ganho de imagem ao se obter uma associação de lentes convergente-convergente.

Após expor essas informações básicas, foi entregue as lentes (ocular e objetiva) para os alunos reconhecerem, manipularem e se familiarizarem mais ainda. As lentes utilizadas para a construção das lunetas foram adquiridas em uma loja fornecedora de lentes para óculos. O técnico óptico ajustou o tamanho das lentes para serem utilizadas nas lunetas.

O primeiro passo foi solicitar aos alunos que obtivessem o foco de cada lente, e para isso apagou-se completamente as luzes da sala de aula, e com o auxílio do aparelho de telefonia celular foi possível realizar a medida, pois enquanto um aluno segurava o celular a uma altura próxima ao teto da sala (subindo em cima de uma cadeira, ou até mesmo da mesa), outro aluno posicionava a lente de forma a tentar "focalizar" a imagem no chão da sala de aula. Ao encontrar a melhor formação da imagem, fez-se então a medida da distância entre a lente e o chão da sala de aula, essa distância foi considerada como o foco da lente. 
Cada grupo fez a medida em centímetros do foco das suas lentes, tanto a objetiva quanto a ocular, como pode ser visto no canto superior direito da lousa na Figura 3.4. Nessa parte, foi extremamente importante o nosso acompanhamento da atividade, pois muitos tinham dificuldade como, por exemplo, de ajustar a posição da lente para formar a imagem e de realizar medidas com as trenas, pois a maioria dos alunos tinha dificuldade de realizar leitura de unidade de medida.

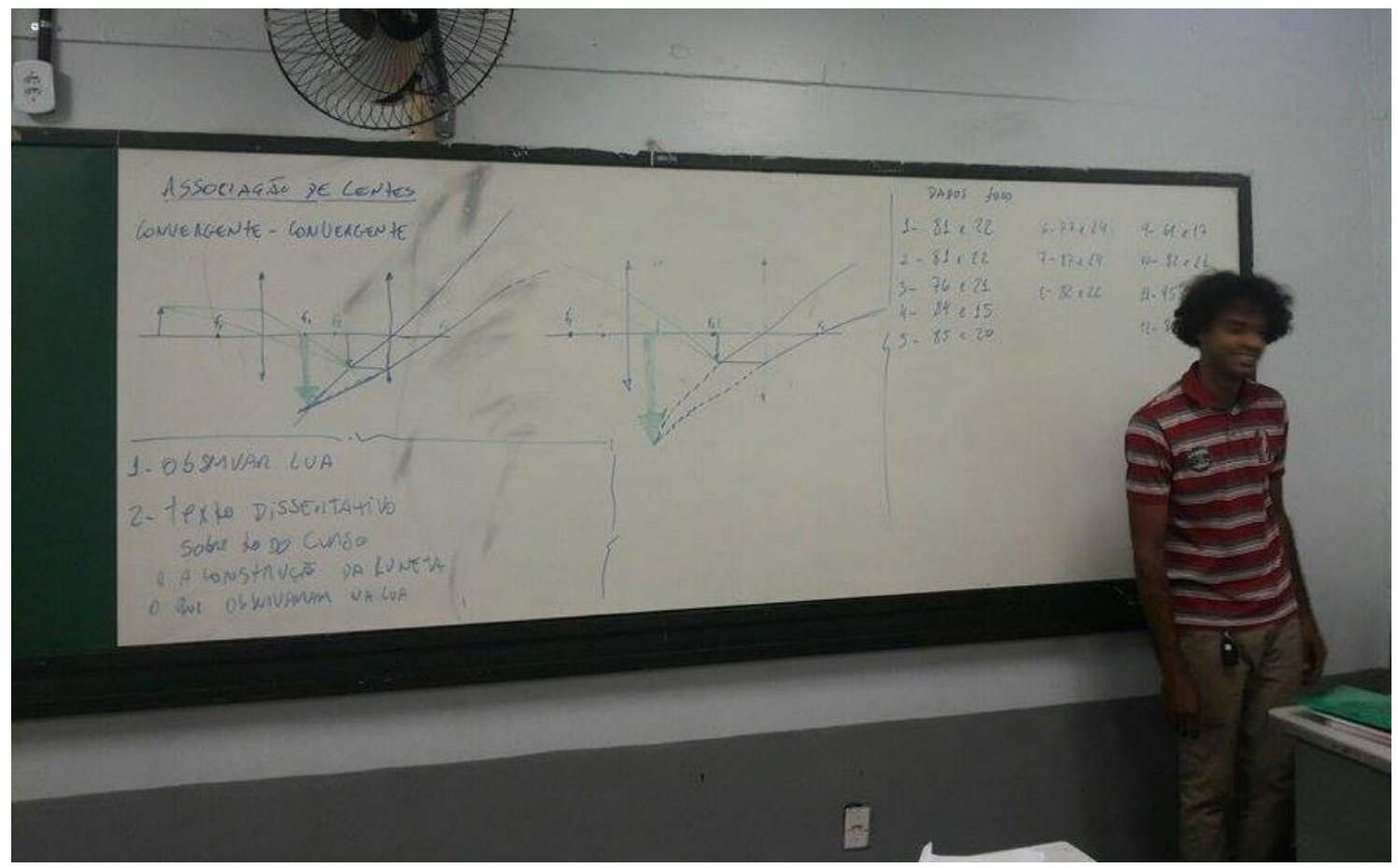

Figura 3.4: Orientação aos alunos para a construção da luneta astronômica.

As medidas de foco das lentes objetivas variaram entre $67 \mathrm{~cm}$ a $87 \mathrm{~cm}$ nos grupos, enquanto as medidas do foco das lentes oculares variaram de $15 \mathrm{~cm}$ a $25 \mathrm{~cm}$. Com esses dados, ficou combinado cortar o cano de suporte da lente objetiva em aproximadamente $50 \mathrm{~cm}$, uma vez que o cano de suporte da lente ocular (já preparado previamente) tinha $50 \mathrm{~cm}$, totalizando uma variação de comprimento da luneta de $60 \mathrm{~cm} \mathrm{a} 110 \mathrm{~cm}$ (incluindo também o tamanho das conexões receptoras das lentes objetiva e ocular).

Foram entregues as conexões para os alunos poderem montar a luneta, bem como o cano já cortado, já que é importante não deixar os alunos manipularem ferramentas de corte (por causa do risco de lesão corporal), ou então, caso haja permissão para tal, é conveniente que o professor esteja fiscalizando constantemente. Dessa forma, acompanhamos a montagem da luneta pelos alunos, como pode ser visto na Figura 3.5. 


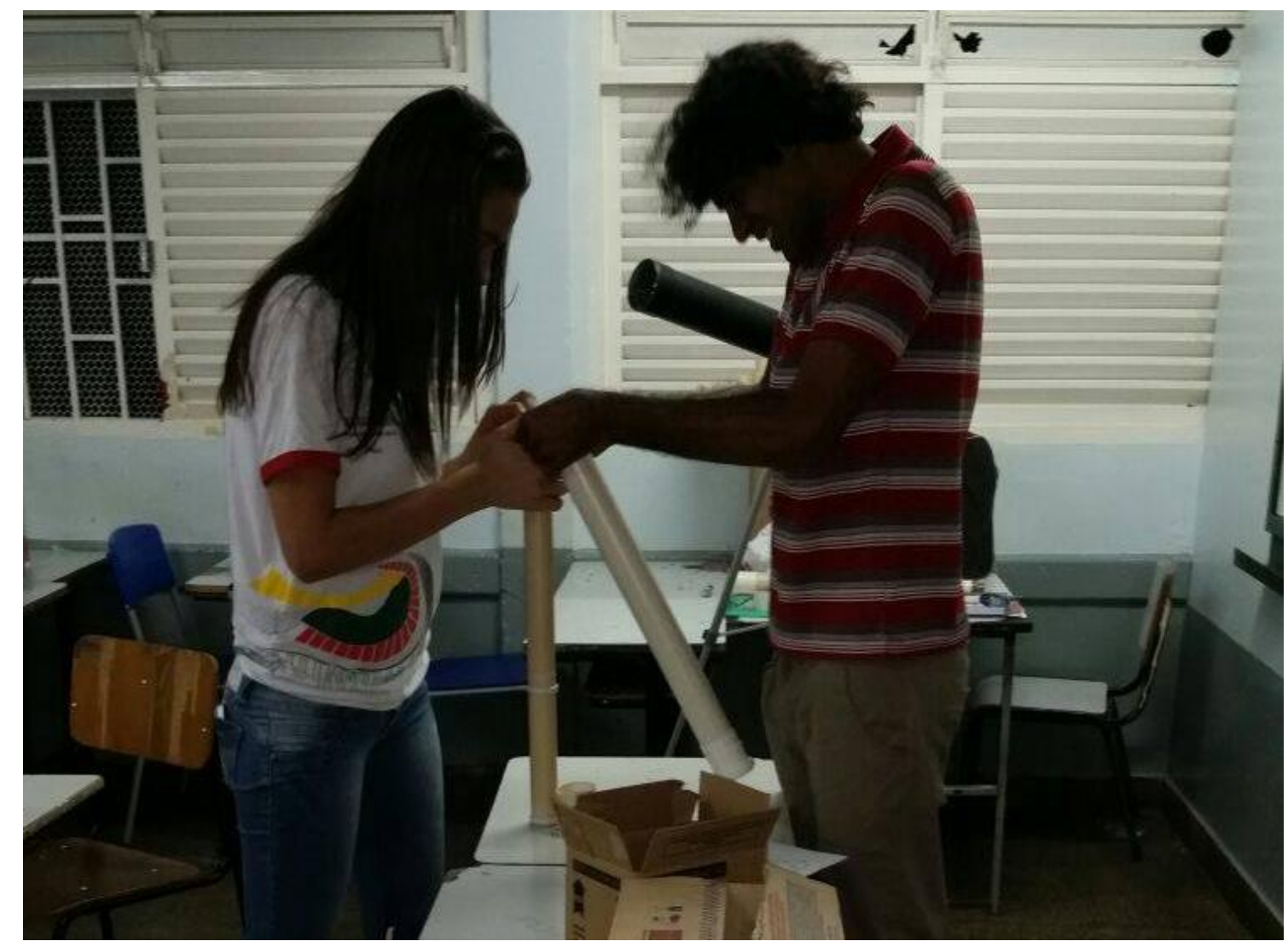

Figura 3.5: professor e aluno trabalhando na montagem da luneta astronômica.

Notamos dificuldade por parte dos alunos em fazer os encaixes dos canos e das junções. Por essa razão, foi necessário ajudá-los, como pode ser visto na Figura 3.5, pois nessa hora também há risco dos alunos se machucarem. Em vários momentos, notou-se a cautela dos alunos em manipular as lentes; porém, algumas vezes era preciso orientar os alunos quanto aos cuidados com os delicados materiais ópticos.

Com a finalização da montagem, foi solicitado aos alunos tentarem encontrar a melhor posição para visualização das imagens na luneta. Os alunos ficaram à vontade para realizar visualizações, tanto na sala como no corredor da escola (fato que deixou a direção um pouco desconfortável por conta da indisciplina no turno).

Nos minutos finais da aula, foi realizada uma atividade que consistia na visualização dos cartazes com o nome "Óptica Geométrica" em diferentes tamanhos de fontes (Arial, de tamanho variando entre 10 e 300). Solicitou-se aos alunos que ocupassem os fundos da sala de aula, e em seguida foi afixado o cartaz na lousa. O objetivo era os alunos fazerem a leitura do cartaz utilizando a luneta. Os alunos conseguiram realizar a tarefa e, segundo eles, conseguiram visualizar todos os tamanhos de letras do fundo da sala. 
Após as atividades, os alunos foram para quadra da escola, onde puderam visualizar uma torre de celular próxima, uma caixa d'água e algumas estrelas isoladas. Não foi possível realizar a observação astronômica mais apurada, pois o céu estava um pouco nublado. Os alunos ainda foram orientados a não olhar para o Sol com esse instrumento de observação, pois podem causar danos a visão e até mesmo a cegueira. Na Figura 3.6 é possível observar essa atividade realizada na turma 2E.

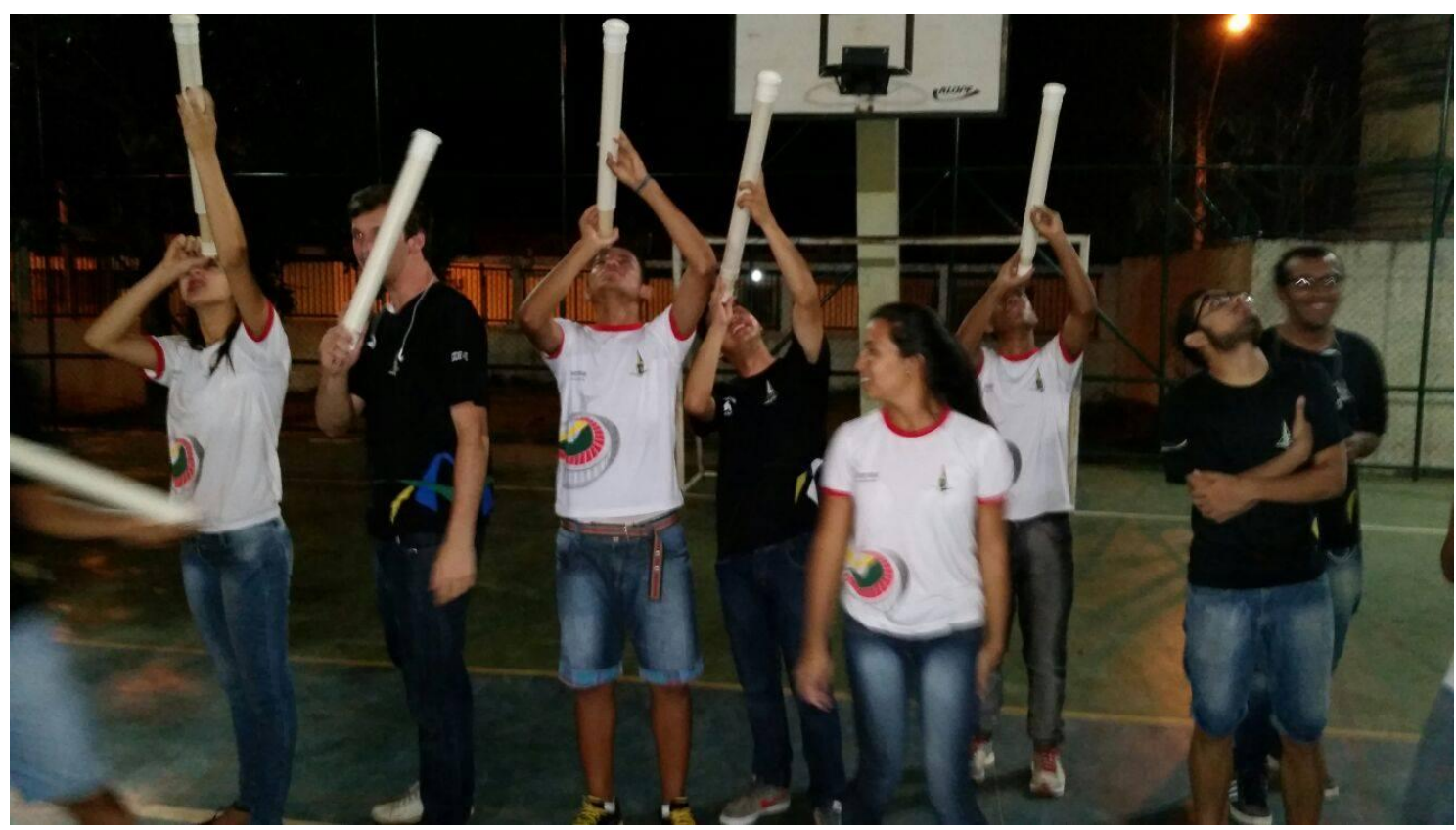

Figura 3.6: observação na quadra poliesportiva da escola

Foi solicitado aos alunos que numa atividade extraclasse fosse feita uma observação à Lua e alguns planetas (caso conseguissem). Além disso, foi solicitado aos alunos que produzissem um texto dissertativo, comentando o que acharam do desenvolvimento da construção da luneta, o que conseguiram observar ao longo da aula e se conseguiram observar a Lua ou outros planetas.

\subsubsection{Quinta aula}

Nessa aula, foi realizada a prova (ver Apêndice D), sobre os conteúdos de refração, lentes esféricas e a luneta galileana. 


\section{Capítulo 4.}

\section{Resultados obtidos e Análises}

Nesse capítulo, abordamos e analisamos os dados obtidos nas tarefas realizadas em sala de aula. Especificamente, da aplicação de dois testes simples (ver Apêndice A e B), uma Lista de Exercícios (Apêndice C) e uma Prova (ver Apêndice D) e um Texto Dissertativo, ao longo do desenvolvimento das aulas.

O trabalho desenvolvido com as duas turmas de segundo ano do Ensino Médio foi realizado inicialmente com aulas tradicionais, o professor regendo o conteúdo e os alunos como agentes passivos prestavam atenção e copiavam o conteúdo, que abrangeu os tópicos desde a natureza da luz até espelhos esféricos, como detalhado no Capítulo 3. Durante esse período de aulas tradicionais, os alunos foram treinados a resolver exercícios, para em seguida realizar dois testes, em que foi possível medir o nível de aprendizagem dos alunos antes de realizar a proposta de trabalho da construção das lunetas, que envolveram aulas práticas.

A lista de exercícios que foi aplicada (ver Apêndice C) correspondeu às aulas sobre refração da luz e lentes, com objetivos de montar da luneta. Em seguida, aplicamos uma prova (ver Apêndice D) para averiguar o conhecimento adquirido pelos alunos também nesses temas.

O Texto Dissertativo foi uma atividade em que o aluno expressou sua opinião a respeito das aulas e do trabalho prático com as lentes durante a construção da luneta. Para o texto dissertativo, foi pedida a opinião dos alunos a respeito das aulas práticas e a construção da luneta, e como resultado os alunos descreveram comparações entre as aulas tradicionais e as aulas práticas.

As notas dos alunos foram totalizadas em 2,0 (dois) pontos para cada atividade (Teste 1, Teste 2, Prova e Texto Dissertativo). Em adição, outros dois pontos foram dados aos alunos que construíram a luneta.

É conveniente analisar os resultados dos dois momentos - (a) o cenário tradicional, avaliado com Teste 1 e Teste 2, e (b) o cenário prático, avaliado com a prova e o texto dissertativo. Nem todos os alunos participaram de todas as avaliações, de forma que selecionamos para uma análise do diagnóstico das avaliações apenas os alunos que realizaram todas as avaliações, que estão descritos na subseção 4.1.4. Realizamos também uma análise da correção da lista de exercícios, e, por fim, 
selecionamos um total de trinta e três textos dissertativos de ambas as turmas, em que os alunos se expressaram sobre as aulas e fizeram críticas relevantes ao trabalho prático. Sendo assim, dividimos os resultados e análise dos resultados em dois tipos de avaliação: quantitativa e qualitativa.

\subsection{As avaliações quantitativas}

Como dito anteriormente, as avaliações foram o Teste 1 (ver Apêndice A), Teste 2 (ver Apêndice B) e a Prova (ver Apêndice D). Todas essas avaliações têm caráter tradicional, porém na Prova havia mais questões conceituais, possibilitando ao aluno obter sucesso independente das suas habilidades matemáticas, caso a compreensão do fenômeno fosse razoável.

Para uma melhor análise dos resultados das avaliações, fizemos uma checagem das notas das duas turmas (2E e 2F), avaliação por avaliação, e depois uma comparação das três avaliações de cada turma separadamente.

\subsubsection{Teste 1}

Essa avaliação era composta de duas questões, a primeira com cinco itens e a segunda com quatro itens (ver Apêndice A).

O objetivo da primeira questão foi avaliar o conhecimento dos alunos sobre as cores primárias e as cores secundárias da luz, bem como a composição da luz monocromática e policromáticas, distinguindo as cores observadas quando a luz incide em um corpo.

$\mathrm{Na}$ segunda questão, o objetivo foi avaliar a compreensão dos alunos sobre a câmara escura e a formação de imagens nesse instrumento.

\subsubsection{Teste 2}

O Teste 2 foi composto de cinco questões, em que os alunos deveriam apresentar cálculos matemáticos. Em apenas uma das questões, os alunos tinham que apresentar resposta conceitual (ver Apêndice B).

$\mathrm{Na}$ primeira questão os alunos tinham que calcular a distância da imagem ao vértice do espelho, utilizando a Equação de Gauss, o que exigia a compreensão da medida de foco como sendo a metade do valor do raio de curvatura desse espelho. 
$\mathrm{Na}$ segunda questão, o aluno também devia aplicar a Lei de Gauss, sendo que dessa vez ele calcularia o valor do foco do espelho, de posse das informações de distância do objeto ao vértice e distância da imagem ao vértice.

$\mathrm{Na}$ terceira questão, foram apresentadas ao aluno as informações da proporção entre tamanho da imagem e tamanho do objeto e ainda a distância entre a imagem e o objeto. Por relação do triângulo retângulo, era possível achar o valor da distância da imagem ao vértice e $\log$ a distância do objetivo ao vértice. Na última etapa, o aluno teria que achar o valor do foco através da Lei de Gauss.

A quarta questão era conceitual, e como o tipo de imagem produzida por um espelho convexo é sempre virtual, direita e reduzida, o aluno tinha que descrever essas características para imagem do objeto formada por esse espelho.

Na última questão, o aluno tinha a informação de altura e distância do objeto e ainda o raio de curvatura; assim, com o valor do foco (metade do raio de curvatura) e distância do objeto, o valor de distância da imagem era encontrado ao aplicar a Lei de Gauss. Já de posse do valor da distância da imagem e da distância do objeto e tamanho do objeto, usava-se a relação de triângulos retângulos e encontra-se o tamanho da imagem.

Sendo assim, o aluno teria que ter habilidade de aplicar a Lei de Gauss e a relação entre triângulos retângulos e ainda o conhecimento teórico a respeito dos espelhos esféricos para conseguir sucesso nesse teste.

\subsubsection{Prova}

Como dito anteriormente, a prova corresponde à avaliação das aulas no cenário prático. Essa avaliação buscou uma compreensão mais conceitual do fenômeno estudado.

$\mathrm{Na}$ primeira questão, a resposta seria satisfatória caso o aluno respondesse que a diferença entre o telescópio newtoniano e a luneta galileana seria o uso de espelhos nos telescópios refratores, enquanto nos telescópios refletores havia uso apenas de lentes.

$\mathrm{Na}$ segunda questão, o aluno tinha que diferenciar as lentes desenhadas, a primeira biconvexa, a segunda plano-côncava e a terceira plano-convexa.

$\mathrm{Na}$ terceira questão era solicitado obter a distância da lente em que é formada a imagem. Para isso, era necessário aplicar a Lei de Gauss, sendo que a informação do foco vem da informação de que os raios do sol (por virem de uma distância tão grande da lente é considerado infinito) convergem no foco da lente, e, com a informação da 
distância do objeto a lente, era possível aplicar a Lei de Gauss e achar a distancia da imagem à lente.

$\mathrm{Na}$ quarta questão, percebe-se que independente da distância que o objeto é colocado da lente, a imagem formada é sempre virtual, direita (não está invertida) e reduzida.

$\mathrm{Na}$ quinta questão, o aluno tinha que desenhar um esquema de pelo menos dois raios notáveis de luz para representar a formação da imagem na figura. Desde que o aluno ilustrasse a formação da imagem segundo posição (antes do foco, entre o foco e o centro de curvatura ou depois do centro de curvatura), tamanho (reduzida ou ampliada) e disposição (normal ou invertida), não foi cobrado um desenho com exata precisão.

\subsubsection{Diagnóstico das avaliações}

Verificamos que nas duas turmas que o desempenho no Teste 1, tanto a turma $2 \mathrm{E}$ como a $2 \mathrm{~F}$, apresentou uma média baixa, sendo que as notas no $2 \mathrm{E}$ não ultrapassaram o valor de 0,6 , e as do $2 \mathrm{~F}$ não ultrapassaram o valor de 0,7 . Podemos justificar esse rendimento tão insatisfatório pelo fato de ser a primeira avaliação da matéria (regime de semestralidade no Distrito Federal), mas também pelo fato de uma parte das questões exigir uma aplicação matemática, na qual os alunos sentem grande dificuldade.

Já no Teste 2, houve uma melhora no desempenho em função do aumento das notas de alguns alunos, em ambas as turmas. Tal diferença pode ser justificada pela grande repetição de exercícios em sala de aula, bem como pelo fato desta avaliação ter sido elaborada com questões parecidas com as dos exercícios realizados antes. Os alunos que não realizaram os exercícios ou não tiveram atenção nas correções dos exercícios, apresentaram um rendimento baixo.

A Prova (avaliação do momento prático) tinha apenas uma questão de aplicação matemática, e as demais eram conceituais. Alguns alunos não alcançaram rendimento por que "estudaram errado", como alguns expuseram. Segundo eles, "cobravam muita matemática" até então, e de repente a prova foi mais "de escrever". Afirmações como essas foram realizadas por alguns alunos com bom rendimento até então, o que justificou a esses não estarem incluído nessa ampliação das notas.

No gráfico da Figura 4.1 é possível visualizar o desempenho da turma 2E durante as três avaliações. 


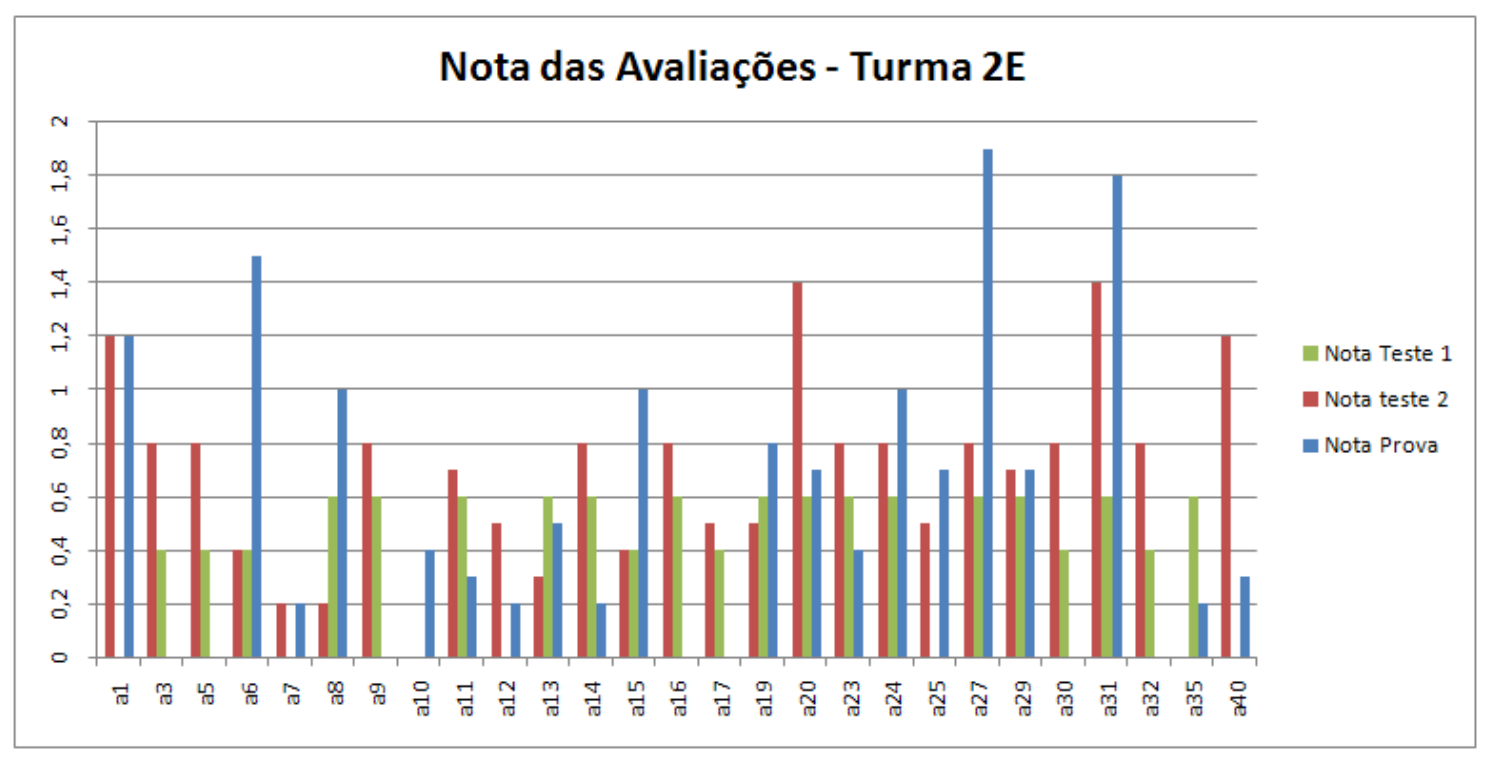

Figura 4.1: Gráfico de desempenho da turma 2 E nas três avaliações.

As notas da prova tiveram maior alcance, ou seja, mais alunos se destacaram e alcançaram médias acima de 1,0 ponto. Se tomarmos uma amostra de alunos que realizaram as três atividades totaliza-se 13 estudantes.

Desses temos que a6, a8, a15, a19, a24, a27, e a31, um total de sete alunos, tiveram aumento em suas notas, sendo que 4 deles, a6, a15, a27, e a31, dobraram o valor de suas notas. Já três alunos, a11, a14, a23, reduziram suas notas em relação aos dois testes, e dois alunos, a13 e a29, mantiveram em média as notas testes-prova, e a20 que teve um superávit no teste 1 , no teste 2 baixou a nota e na prova praticamente manteve a nota.

O gráfico da Figura 4.2 apresenta o desenvolvimento dos alunos do Teste 1 e Teste 2 (momento tradicional), em comparação à Prova (momento prático).

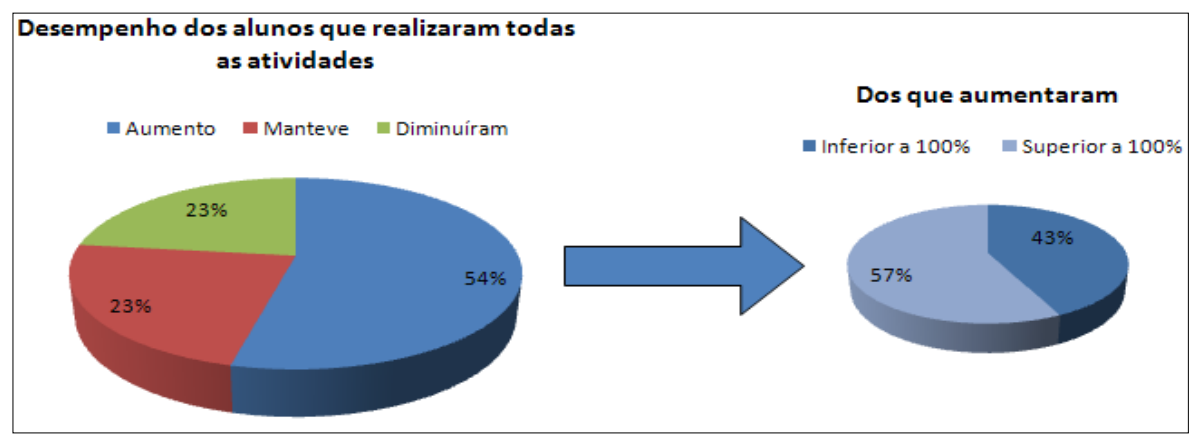

Figura 4.2: Gráfico do desempenho da turma 2E. A esquerda o desenvolvimento frente as três avaliações. A direita detalhamento dos alunos que alcançaram aumento de nota. 
$\mathrm{Na}$ turma 2F o desempenho em média é maior em todas as atividades. Na figura 4.3 é possível analisar as notas da classe nas três avaliações.

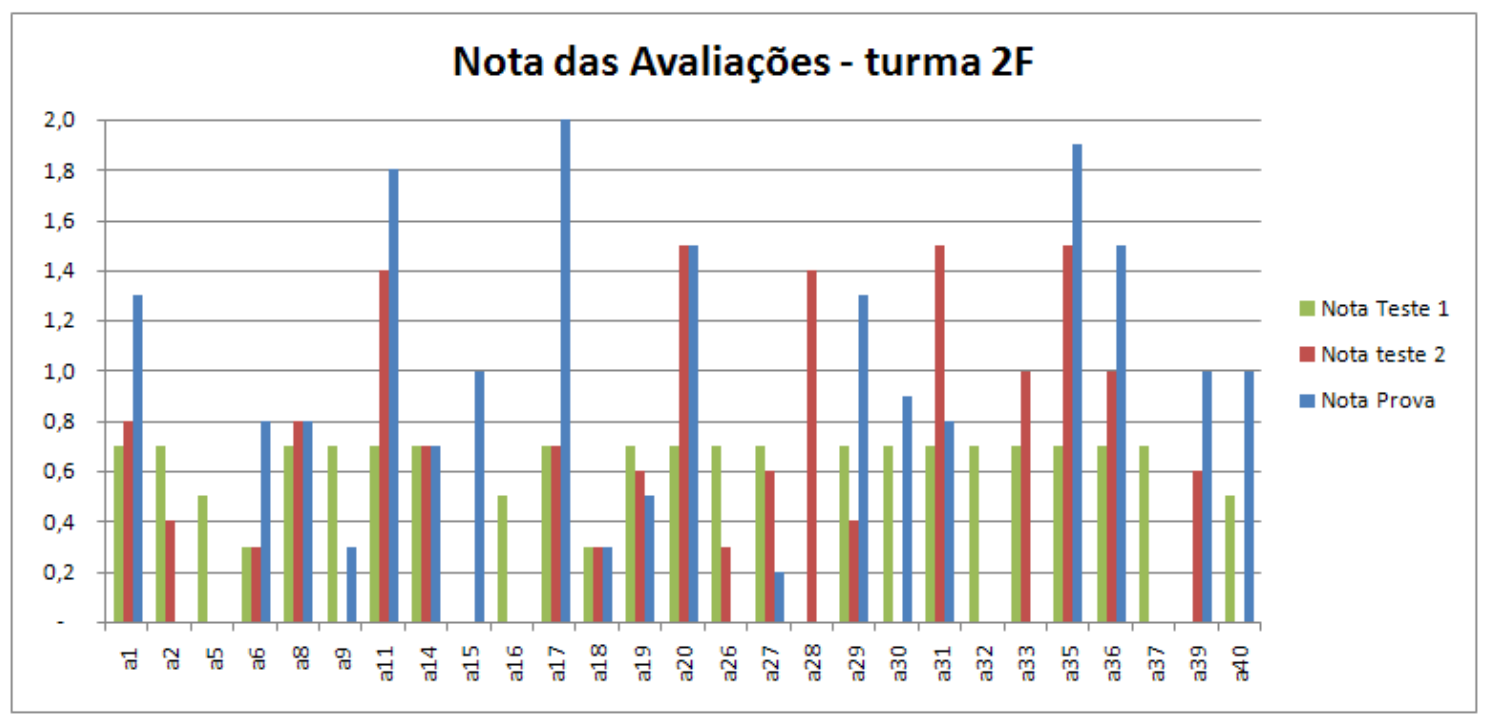

Figura 4.3: Gráfico de desempenho da turma $2 F$ nas três avaliações

As notas da prova desta turma também tiveram maior alcance, sendo possível notar que houve uma nota máxima. Se novamente tomarmos uma amostra de alunos que realizaram as três atividades totaliza-se nessa turma 14 estudantes.

Desses temos que a1, a6, a11, a17, a20, a29, a35 e a36, um total de 8 alunos, conseguiram aumentar suas notas em relação a média dos dois testes, sendo que três alunos, a6, a17 e a29 dobraram suas notas. A observação vem do aluno a20 que obteve a mesma nota do Teste 2 na Prova. Três alunos, a8, a14 e a18, mantiveram seus resultados. E por fim, os alunos a19, a27 e a31, reduziram suas notas em relação aos dois testes.

Dessa maneira, o gráfico da Figura 4.4 permite observar o desenvolvimento dos alunos da turma $2 \mathrm{~F}$ na média do Teste 1 e Teste 2 (momento tradicional), em comparação à Prova (momento com foco na construção do equipamento).

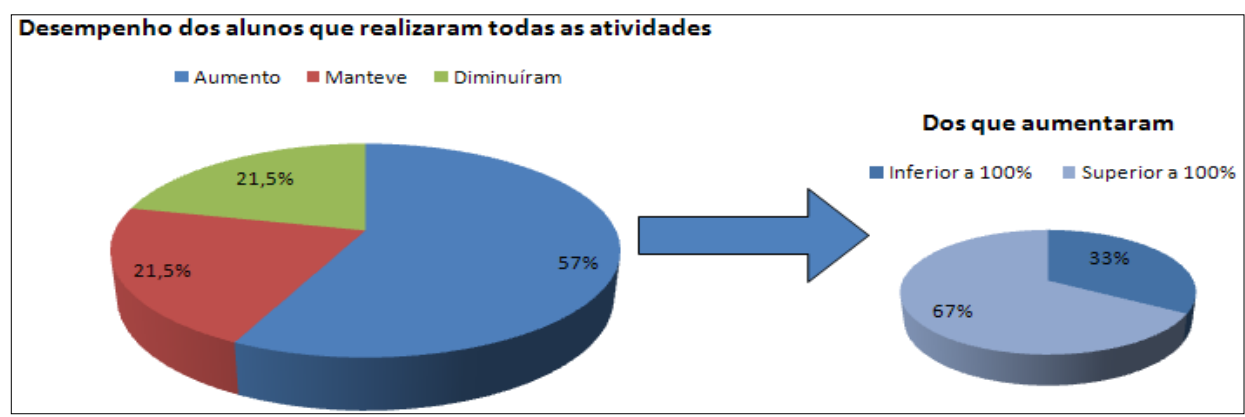

Figura 4.4: Gráfico do desempenho da turma $2 \mathrm{~F}$. A esquerda o desenvolvimento frente as três avaliações. A direita detalhamento dos alunos que alcançaram aumento de nota. 


\subsection{Avaliações qualitativas}

Aplicamos duas atividades que não se enquadram no modelo das avaliações citadas no item 4.1, por se tratar de uma avaliação qualitativa e também por serem tarefas realizadas extraclasse que são: a lista de exercícios e o texto dissertativo (redação).

Tanto a lista de exercício quanto o texto dissertativo tiveram o propósito de averiguar a aprendizagem dos alunos sem fins punitivos, principalmente na hora de escrever sua redação sobre as aulas práticas, em que o aluno pôde se expressar livremente. Vale ressaltar que a lista de exercício valia 1,0 ponto extra e o texto dissertativo, com no mínimo 20 linhas, valia 2,0 pontos.

\subsubsection{Lista de Exercícios}

Essa tarefa foi entregue aos alunos na segunda aula e corrigido juntamente com a turma na terceira aula. O maior objetivo dessa avaliação foi apontar as dificuldades que os alunos vinham apresentando na compreensão do conteúdo, e assim poder reforçar os conteúdos que foram aprendidos nas aulas anteriores.

Como dito no capítulo anterior (item 3.2.3), as principais dificuldades dos alunos com relação às primeiras aulas do cenário prático foram: (a) diferenciar lentes côncavas e convexas; (b) reconhecer que a luz que vem de objetos distantes, como por exemplo o Sol, chegam praticamente em paralelo; (c) resolver equações de Gauss; (d) proporcionalidade de triângulos e (e) desenvolver problemas com mais de uma etapa de resolução. Nas aulas práticas com as lentes, os alunos passaram a entender melhor e a diferenciar as lentes côncavas e convexas. Dessa forma, os alunos compreenderam os elementos geométricos das lentes esféricas, o que contribuiu para o melhor entendimento e resolução das equações de Gauss.

\subsubsection{Texto Dissertativo}

Pedimos aos alunos que expressassem suas opiniões a respeito das aulas de Óptica Geométrica, mais precisamente das aulas do cenário prático. Para isso, solicitamos aos estudantes escreverem um texto dissertativo (redação) com no mínimo vinte linhas.

Dessa maneira, e como dito anteriormente, selecionamos 33 textos dissertativos de ambas as turmas, e fizemos análise sem fazer menção a uma turma ou outra, por se 
tratar de opinião pessoal em que os alunos puderam se expressar livremente, fazendo críticas relevantes ao trabalho prático.

As redações foram lidas e analisadas, e constatamos nos textos as opiniões dos alunos quanto a quatro níveis que julgamos básicos a este trabalho:

1. O trabalho prático é fácil de ser realizado.

2. Compreendeu bem ofuncionamento da luneta.

3. Conseguiu realizar observação com a luneta.

4. É favorável a continuação deste trabalho.

A Tabela 4.1 mostra a opinião quanto aos quesitos propostos.

\begin{tabular}{|c|c|c|c|c|c|}
\hline \multicolumn{6}{|c|}{ OPINIÃO DOS ALUNOS QUANTO AO TRABALHO DESENVOLVIDO } \\
\hline Quesito & Sim & Indiferente & Não & Não opinou & TOTAL \\
\hline $\begin{array}{c}\text { Trabalho prático é } \\
\text { fácil de ser } \\
\text { realizado }\end{array}$ & 22 & 1 & 4 & 6 & $\mathbf{3 3}$ \\
\hline $\begin{array}{c}\text { Compreendeu bem } \\
\text { ofuncionamento } \\
\text { da luneta }\end{array}$ & 12 & 11 & 7 & 3 & $\mathbf{3 3}$ \\
\hline $\begin{array}{c}\text { Conseguiu realizar } \\
\text { observação com a } \\
\text { luneta }\end{array}$ & 16 & 6 & 6 & 5 & $\mathbf{3 3}$ \\
\hline $\begin{array}{c}\text { É favorável a } \\
\text { continuação deste } \\
\text { trabalho }\end{array}$ & 18 & 1 & 4 & 10 & $\mathbf{3 3}$ \\
\hline
\end{tabular}

Tabela 4.1: opinião dos alunos quanto ao trabalho desenvolvido (os dados foram extraídos dos textos dissertativos dos alunos)

O gráfico da Figura 4.5, elaborado com base nos dados da Tabela 4.1, permite melhor visualização quanto à opinião dos alunos sobre o trabalho realizado. 


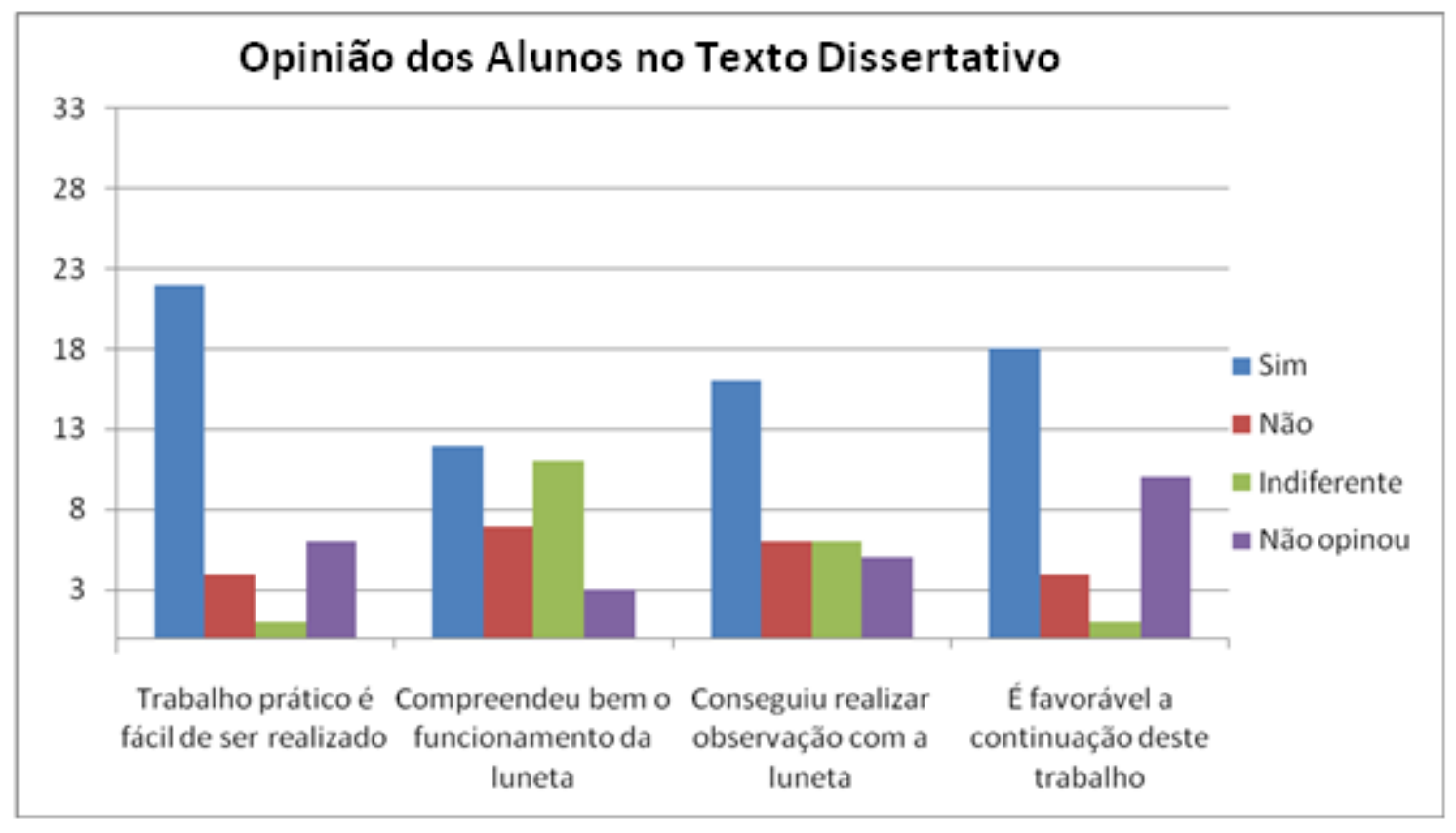

Figura 4.5: Gráfico da opinião dos alunos sobre o trabalho. Dados extraídos da Tabela 4.1 


\section{Capítulo 5.}

\section{Conclusão}

Este trabalho de Mestrado Nacional Profissional em Ensino de Física é uma iniciativa em unir tópicos de Óptica com a construção de um instrumento de observação astronômica. No Capítulo 1 fizemos uma introdução expondo quais são as vantagens em se estudar temas de Astronomia em conjunto com tópicos de Física. Abordamos considerações de alguns autores (CANNIATO, 1974), (MOURÃO, 2000), (LANGHI e NARDI, 2012), que defendem o uso dos temas de Astronomia para incitar a curiosidade e o estudo de Física entre os estudantes do Ensino Médio.

Assumimos a premissa de que a Astronomia é uma porta de entrada para estudos de disciplinas das ciências, principalmente à Física. Podemos destacar que os tópicos da Lei da Gravitação Universal, incluindo aí as Leis de Kepler, já são temas naturais à Astronomia e à Física. Contudo, existem vários tópicos em eletromagnetismo, termodinâmica, Física Moderna, etc. que podem ser aplicados ao ensino de Astronomia como disciplina motivadora para o estudo desse temas da Física. Este trabalho teve por objetivo chamar a atenção dos estudantes de Ensino Médio para o tema de óptica e sua relevância para o entendimento e a construção de um telescópio refrator.

Como foi dito no Capítulo 1, os professores idealistas comprometidos com a educação, em especial os professores em início de carreira, deparam-se com vários obstáculos nas escolas, como a rotina e acomodação do "statu quo" que os inibem de realizar aulas diferenciadas. Por isso é necessário pensar em estratégias que rompam com a estagnação de muitas escolas. Então propusemos um trabalho para incentivar os alunos a construírem um telescópio refrator apoiado nas aulas práticas e expositivas de óptica geométrica.

As importantes observações astronômicas de Galileu questionaram o antigo pensamento aristotélico e romperam com este paradigma, com isso abriram-se as portas para a Física Clássica de Newton. Então acreditamos que da mesma forma, um estudante que vier a usar um telescópio galileano possa confirmar pessoalmente o que Galileu propôs no século XVII. Isso é a aprendizagem significativa (MOREIRA,1999) em que o aluno constrói seu próprio conhecimento de maneira efetiva, e não mecânica (decorando). Por isso, propusemos aos alunos do segundo ano do Ensino Médio, ao 
estudar o tópico de óptica geométrica, a aplicação dos conteúdos de leis de refração e lentes para construírem uma luneta galileana.

Ao longo da aplicação do projeto, observamos que os alunos passaram a se interessar ainda mais pelo conteúdo quando enxergaram as aplicações práticas e a utilidade desse conhecimento.

Nas aulas tradicionais, observamos o empenho dos alunos em decorar os conteúdos e a mecanizar os exercícios para repeti-los na prova, enquanto nas aulas práticas os alunos observavam o fenômeno de perto, como por exemplo, o experimento de refração da luz realizado em sala de aula (veja a Figura 3.1) e a decomposição da luz (veja a Figura 3.3). Assim, o estudante se sente compelido a compreender os fenômenos observados na prática. Isso foi muito bem observado na primeira aula do cenário prático, quando os alunos mostraram atenção durante a desmontagem da luneta. Durante as aulas práticas, observamos que a apatia e indisposição demonstrada pelos alunos durante o cenário tradicional, foram vencidas pela dedicação e empenho ao construir e compreender a luneta galileana. A indisciplina que na maioria do ano foi um problema nas duas turmas, cedeu espaço para a concentração no trabalho. Ao finalizarem as lunetas, os alunos foram para o pátio da escola para fazer observação astronômica, chamando a atenção do restante da escola.

Foi possível notar o impacto e a consequência das aulas práticas nas avaliações dos alunos, descrito no Capítulo 4. Na análise das avaliações quantitativas observamos que boa parte dos alunos conseguiu notas mais altas na prova correspondentes às aulas práticas (veja os gráficos da Figura 4.1 e Figura 4.3).

No gráfico da Figura 4.2 e no gráfico da Figura 4.4 observamos o desempenho das turmas $2 \mathrm{E}$ e $2 \mathrm{~F}$ nas avaliações quantitativas. Podemos notar que mais de $50 \%$ dos alunos de ambas as turmas aumentaram suas notas quando mudamos a estratégia de aula (Cenário Tradicional para o Cenário Prático), o que demonstra que grande parte da turma teve maior indício de aprendizagem nas aulas do Cenário Prático. Entretanto, entre $21,5 \%$ e $23 \%$ dos alunos em ambas as turmas mantiveram suas notas. E também, entre $21,5 \%$ e $23 \%$ dos alunos diminuíram suas notas.

Afirmamos que a maioria se adequou a esta proposta de trabalho, comprovando que ao ver aplicação e utilidade de um determinado conteúdo, os alunos puderam constatar uma contribuição significativa à sua aprendizagem. Observamos também que as aulas práticas têm maior potencial de atratividade quando ligado ao desenvolvimento de equipamentos ou utensílios que possam ser manuseados pelos alunos. 
Nas avaliações qualitativas, é interessante observar a Tabela 4.1 e o gráfico da Figura 4.5, que corresponde a opinião dos alunos quanto à prática da aula de montagem da luneta galileana. O primeiro item mostra que $66 \%$ dos alunos acharam o trabalho fácil de ser realizado, $12 \%$ não acharam o trabalho fácil de ser realizado, e apenas um aluno foi indiferente e $18 \%$ não opinaram. No segundo item, $36 \%$ dos alunos afirmaram que compreenderam bem o funcionamento da luneta, 33\% foram indiferentes, $21 \%$ não compreenderam bem o funcionamento do equipamento e $10 \%$ não opinaram. No terceiro item vimos que $48 \%$ dos alunos realizaram a observação astronômica, $18 \%$ não conseguiram realizar a observação, $18 \%$ foi indiferente, ou seja, não obteve uma boa observação, na maioria dos casos por conta do tempo (nublado) e 15\% não opinaram. No último item, $54 \%$ dos alunos são favoráveis a continuação das aulas práticas, enquanto $12 \%$ dos alunos são contra, 1 aluno é indiferente e $30 \%$ não opinaram.

$\mathrm{Na}$ análise global, podemos afirmar através de observações descritas nos textos dissertativos dos próprios alunos que a maioria deles se sentiu predispostos às aulas práticas, pois em média, $51 \%$ dos alunos se posicionaram a favor. No entanto apenas $16 \%$ em média expressaram certo desconforto quanto a estratégia das aulas práticas, sendo que $14 \%$ foram indiferentes e $18 \%$ não deram opinião. Desses itens analisados é interessante notar que $66 \%$ dos alunos acharam a prática fácil de ser realizada e $54 \%$ é a favor da continuação desse tipo de aula, o que pode ser comparado com a média de $55 \%$ dos alunos que aumentaram suas notas no gráfico da Figura 4.2 e no gráfico da Figura 4.4 .

Dessa maneira, podemos concluir que as aulas de Óptica Geométrica podem ser mais interessantes se realizarmos um pouco mais de aulas práticas, em que o aluno enxergue a necessidade de aprender os conteúdos para aplicar em algo que possa ter alguma utilidade para ele próprio.

Foi possível realizar uma aula de Astronomia Observacional sem prejudicar o conteúdo normal da disciplina, e ainda conseguimos despertar nos alunos o interesse por observar o céu. Após a execução do projeto, a maioria dos alunos afirmou ter realizado observações astronômicas fora da escola.

Por fim, este trabalho nos foi muito relevante ao permitir verificarmos na prática as afirmações estudadas na literatura (Langhi e Nardi, 2012) e (Mourão, 2000), as quais indicam que o tema de Astronomia pode ser usado para motivar e cativar os alunos para o ensino de diversos temas de ciência, em especial os temas de Física. A Astronomia promove o interesse e desperta à curiosidade científica nas pessoas, gerando assim uma 
proximidade com a ciência, pois a mesma possui um caráter interdisciplinar em seus conteúdos.

Considerando a eficácia da aula de construção da luneta e sua utilização no contexto de aprendizagem, bem como o desempenho dos alunos nas avaliações no momento prático, sugerimos futuros trabalhos com o telescópio refletor, que apesar de ter um custo mais elevado que a luneta galileana, pode ser construído por uma turma de alunos (ao invés de individualmente) e pode ser apresentado em uma feira de ciências ou outro evento escolar semelhante que haja empenho de uma classe em conjunto.

Outras sugestões para trabalhos futuros são outros temas interdisciplinares de Física com Astronomia, que possam ter aplicações práticas, ou mesmo que possam servir de tema motivacional na realização de aulas que possam despertar a curiosidade científica dos alunos. 


\section{Referências Bibliográficas}

(ASSIS, 1998) A. K. T. ASSIS, Newton e suas grandes obras: o Principia e o Óptica, in: Linguagens, Leituras e Ensino da Ciência, M. J. P. M. de Almeida and H. C. da Silva (editors), Mercado de Letras/Associação de Leitura do Brasil, Campinas, 1998

(BRASIL, 2002) BRASIL. Ministério da Educação. Secretaria da Educação Média e Tecnológica. Parâmetros Curriculares Nacionais $+(P C N+)$ - Ciências da Natureza e suas Tecnologias. MEC, Brasília, 2002.

(BONJORNO, 2013) BONJORNO, José Roberto, RAMOS, Clinton Marcico, PRADO, Eduardo de Pinho, CASEMIRO, Renato. Física: Termologia, óptica, ondulatória, $2^{o}$ ano. FTD, São Paulo, 2013.

(CANNIATO, 1974) CANIATO, R. Um projeto brasileiro para o ensino de Física. 1974. V.4, 586f. Tese (Doutorado em Física), Unesp, Rio Claro, 1974.

(CAPES 2015) Listas decursos oferecidos. Disponível em < http://conteudoweb. capes. gov.br/conteudoweb/ProjetoRelacaoCursosServlet?acao=pesquisarArea\&identificador= 46> acesso em agosto de 2015 .

(DA-IF-UFRGS, 2015) Departamento de Astronomia - Instituto de Física da Universidade Federal do Rio Grande do Sul. Disponível em

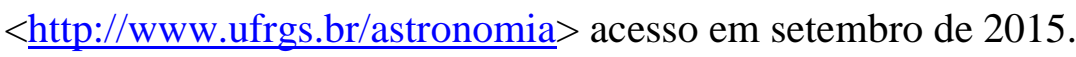

(FREIRE, 1996) FREIRE, Paulo. Pedagogia da autonomia. Paz e Terra, São Paulo, 1996.

(IAGCA, 2015) Instituto de Astronomia Geofísica e Ciências Atmosférica. Disponível em< http://www.iag.usp.br/astronomia/graduacao $>$ Acesso em setembro de 2015.

(LANGHI e NARDI, 2012) LANGHI, Rodolfo; NARDI, Roberto. Educação em Astronomia: repensando a formação de professores

(LIGO LAB, 2015) Laser InterferometerGravitational-Wave Observatory. Disponível em: $\langle\underline{w w w . l i g o . c a l t e c h . e d u}>$ acesso em setembro de 2015. 
(LOPES, 2014) LOPES, Eric Barros. Refração e o Ensino de Óptica. Dissertação de mestrado. Universidade Federal do Rio de Janeiro, Rio de Janeiro, 2014

(MOREIRA,1999) MOREIRA, M. A. Aprendizagem significativa. Editora da UnB. Brasília, 1999.

(MOREIRA, 2014) MOREIRA, Marco Antonio. O mestrado profissional em ensino e seu potencial de impacto na educação básica. Instituto de Física, UFRGS. Porto Alegre, 2014.

(MOURÃO, 2000) MOURÃO, Ronaldo Rogério de Freitas. O Livro de Ouro do Universo. Ediouro, Rio de Janeiro, 2000.

(OV- UFRJ, 2015) Observatório de Valongo - Universidade Federal do Rio de Janeiro. Disponível em <http://www.ov.ufrj.br/graduacao/> acesso em setembro de 2015.

(POLITO, 2015) POLITO, A.M.M. A Metafísica e a Física de Aristóteles. Physicae Organum, vol.1, n. 2. Brasília, 2015

(SANTOS, 2010) SANTOS, Walter da Silva. Refração, as velocidades da luz e metamateriais. Dissertação de mestrado. Universidade Federal do Rio de Janeiro. Rio de Janeiro, 2010

(SILVA, 2008) SILVA, Benedito Antonio. Contrato Didático. In: MACHADO, Silvia Dias Alcântara. (Org.) Educação Matemática - Uma (nova) introdução. São Paulo. EDUC. 2008, p. 49-75.

(SILVA, 2010) J. Silva e J. Souza, O ensino de Física em Botucatu, Revista Botucatuense de Ensino de Física, v. 97, n. 4, p. 1103-1125, 2010.

(VANNUCCHI, 1996) VANNUCCHI, Andréa Infantosi. História e Filosofia da Ciência: da teoria para a sala de aula. Universidade de São Paulo, São Paulo: 1996. 


\section{Apêndice A - Teste 1}

$\begin{array}{ll}\text { nome: } & n^{2}: 1 \\ \text { nome: ... } & n^{2}: \alpha\end{array}$

\section{Teste 1}

1. Gual a cor om que um obseroader ina enxengar os nas Sravintes situcioo:

a) Objets amardo iluminado pon luz dicromótica amarda

b) Ubjeto verde vilumineds por luz dicrsmotica magnte.

c) Gojete ozul uluminods por liz monocromática omavia. d) Gbjets labng iluminodo per liz bionce

e) Glefte puto viluminade pos boira.

2. Determine gider de $x$ nes comaras escuras docixo.

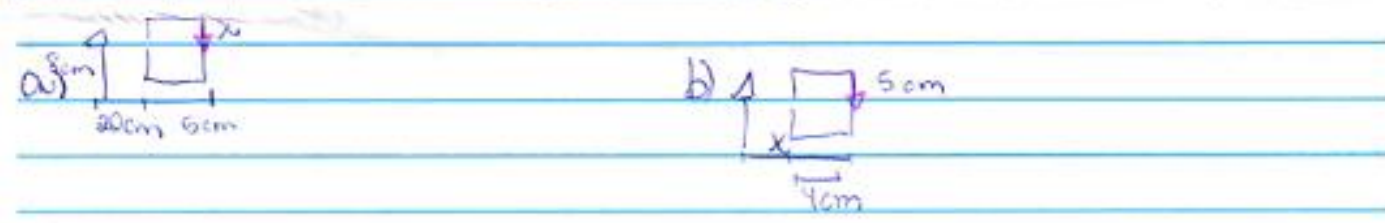

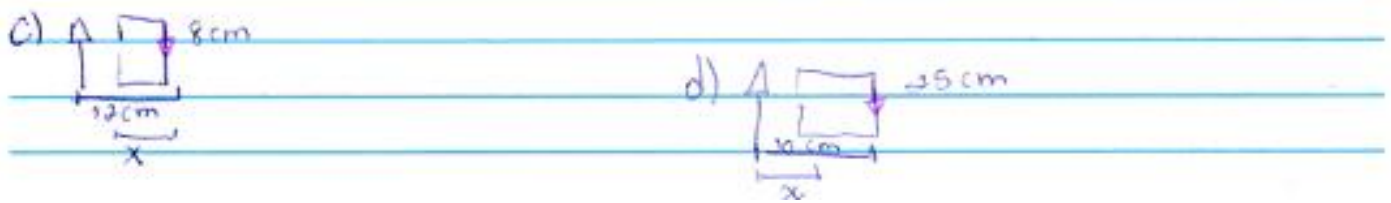




\section{Apêndice B - Teste 2}

\begin{tabular}{|c|c|}
\hline $\operatorname{AlunO}(a)=$ & Ne 10 \\
\hline Aluno(a): & $n=2 \square$ \\
\hline
\end{tabular}

\section{Leiste 02}

1- Um abjeto é colocado a $30 \mathrm{~cm}$ de um espelho côncavo cam ravo de curvatura $40 \mathrm{~cm}$. Determine a posicäo da imagem

2-Um corpo de $40 \mathrm{~cm}$ gera uma magem de $20 \mathrm{~cm}$ ao ser caccado a $30 \mathrm{~cm}$ de um espelho convexo. Determine a distäncia focal do espelino.

Atencäinas coracterísticas da magem formade em um espelho convexo 3-exvendo que o objeto e 3 vezes maior que a unagem, determine a distänoia focal do espetho.

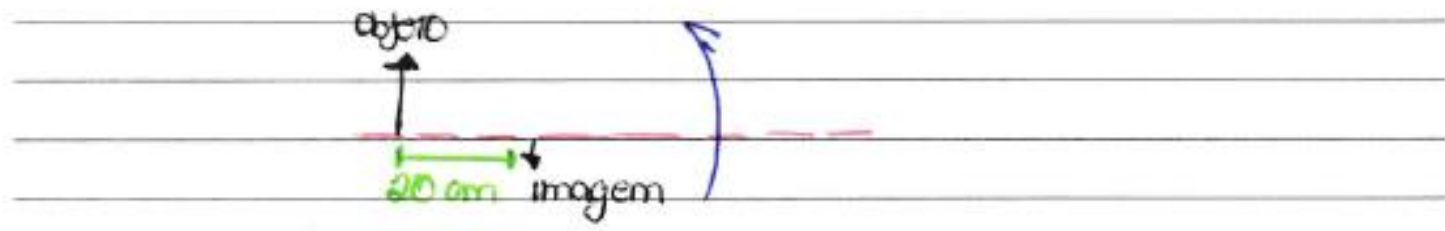

4- Quals as caracteristicas da umagem formada em um espelino convexo?

5- Qual a altora da unagem de um ajeto com $20 \mathrm{~cm}$ de altura, Do ser colocedo a $40 \mathrm{~cm}$ de un eqpetho convexo can $80 \mathrm{~cm}$ de rave de arvatura? 


\section{Apêndice C - Lista de exercícios}

Centro de Ensino Fundamental e Médio Darcy Ribeiro

Nome:

Turma:

Data:

\section{Lista de exercícios}

1. Na figura abaixo explique por que o lápis parece estar "quebrado".

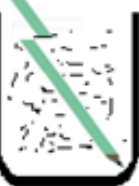

2. Pelo esquema abaixo determine o tipo de lente pelo formato.
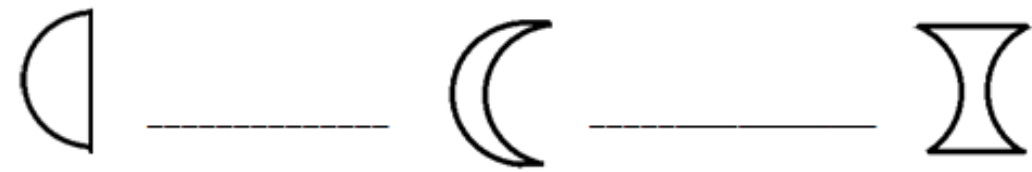

3. Os raios do Sol ao passar por uma lente convergente, se convergem a $10 \mathrm{~cm}$ de distância da lente. Se ao colocar um objeto a $20 \mathrm{~cm}$ desta lente, qual a distância da lente será formada a imagem?

4. Um objeto é colocadono mesmo plano óptico de uma lente convergente de distância focal $30 \mathrm{~cm}$. A imagem visualizada é direita e três vezes maior que o objeto. Sendo assim, determine a distância entre o objeto e a imagem.

5. Na figura abaixo, o objeto de $10 \mathrm{~cm}$ de altura, está no mesmo plano óptico de uma lente convergente de distância focal de $15 \mathrm{~cm}$. À distância em que a imagem é formada é de $25 \mathrm{~cm}$ da lente. A qual a distância do objeto até a lente? Qual o aumento dessa lente?

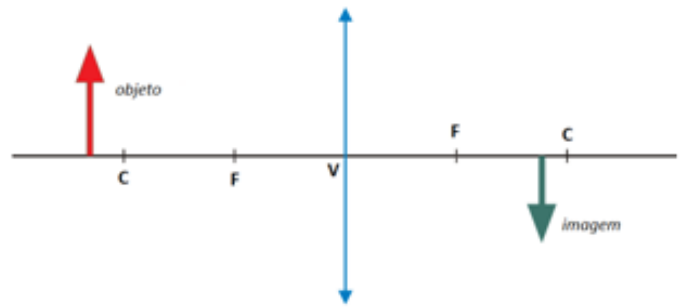




\section{Apêndice D - Prova}

Centro de Ensino Fundamental e Médio Darcy Ribeiro

Nome: №:

Professor: Jefferson / Mateus

Data:

Turma:

\section{Prova de Física}

1. Qual a diferença entre o telescópio newtoniano e a luneta galileana?

2. Determine o tipo de lente pelo formato no esquema abaixo.
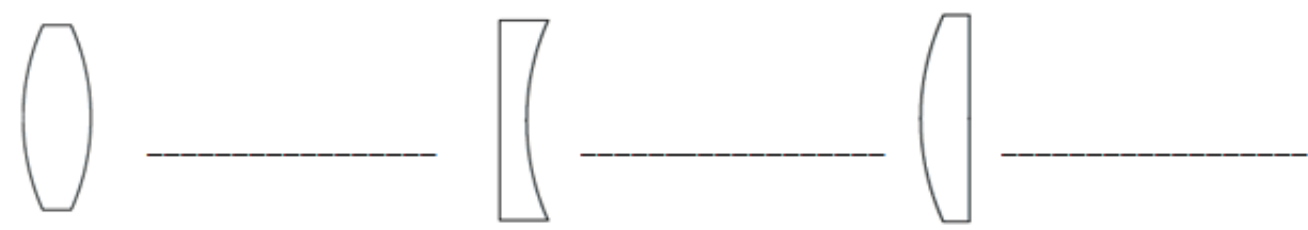

3. Os raios do Sol ao passar por uma lente convergente, se convergem a $10 \mathrm{~cm}$ de distância da lente. Se ao colocar um objeto a $20 \mathrm{~cm}$ desta lente, qual a distância da lente será formada a imagem?

4. Pode-se afirmar que a imagem fornecida por um objeto diante de uma lente divergente é:
a) (n) Real, invertida e mesmo tamanho
b) (n) Virtual, direita e reduzida
c) ( $)$ Virtual, invertida e ampliada
d) (n) Real, direita e ampliada

5. Nas figuras abaixo, complete o desenho da imagem produzida pela lente, explicitando com pelo menos dois raios que saem do objeto, passam pela lente, e formam a imagem.
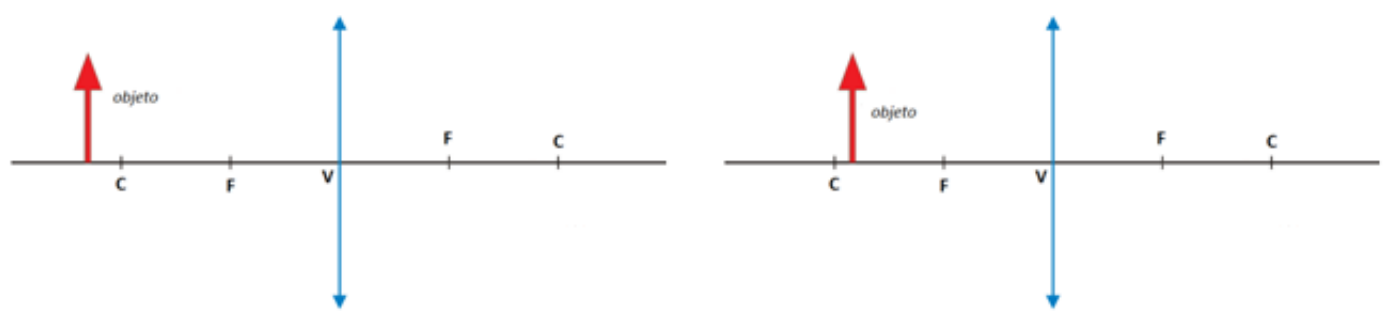

Boa Prova! 


\section{Apêndice E - Produto Educacional}

Mestrado Nacional

Profissional em

Ensino de Física
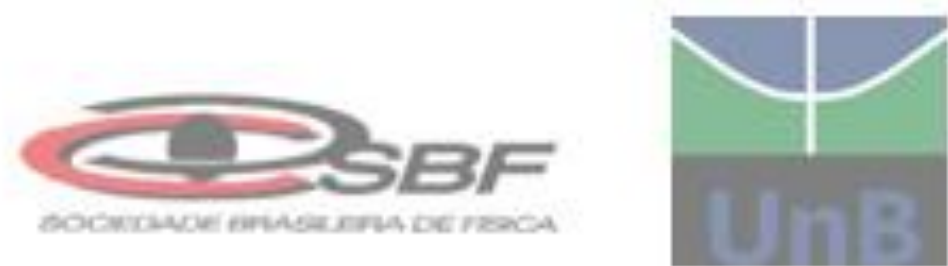

CONSTRUÇÄO DE INSTRUMENTOS DE OBSERVAÇÄO ASTRONOMICA PARA O ENSINO DE OPTICA GEOMETRICA

PRODUTO EDUCACIONAL

JEFFERSON DE SOUSA PEREIRA

Orientador:

Dr. Wytler Cordeiro dos Santos, PhD
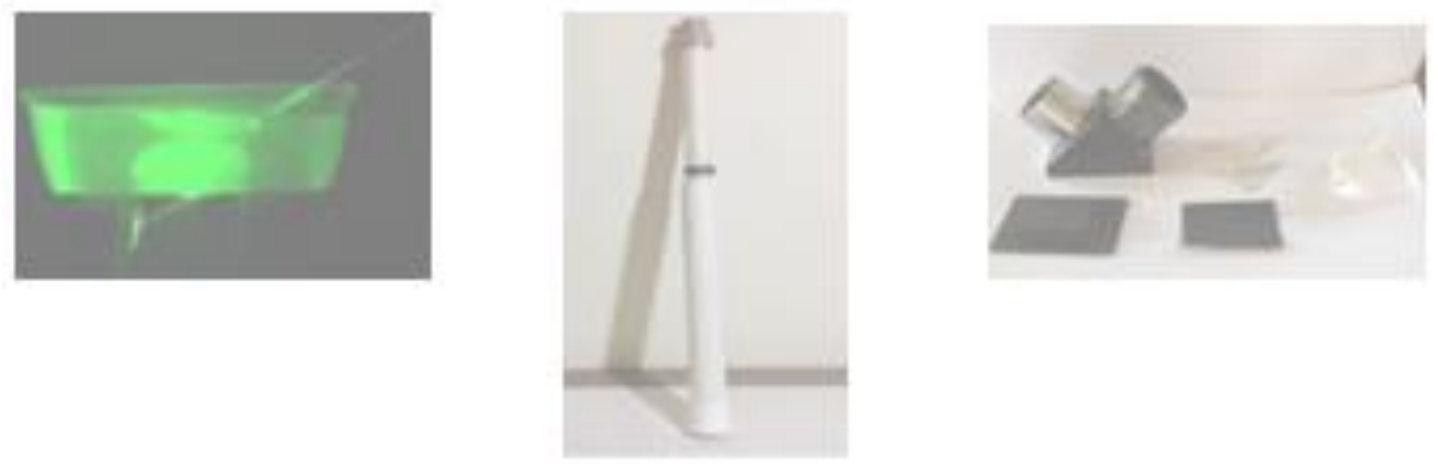


\section{Óptica Geométrica}

\section{- Luz}

A natureza da luz é dual: onda e partícula.

$\mathrm{Na}$ Óptica Geométrica a descrição da luz é através de raios, das leis da reflexão e da refração e da geometria.

Sua propagação é retilínea e uniforme, ou seja, se desloca em linha reta e com velocidade constante.

\section{- Cores e pigmentos}

Cor é uma característica da luz ligada a sua frequência de onda, que constituí num feixe luminoso.

Pigmento é um atributo de cor relacionado um corpo ou objeto, que pode ser colorido por uma tinta.

As cores básicas da luz são dividas em dois grupos:

> Primárias: azul, vermelho e verde.

> Secundárias: amarelo, magenta e ciano.

Na figura 1 abaixo é possível notaras cores primárias nos círculos e a mistura das cores como interseção dos círculos, que são as cores secundárias.

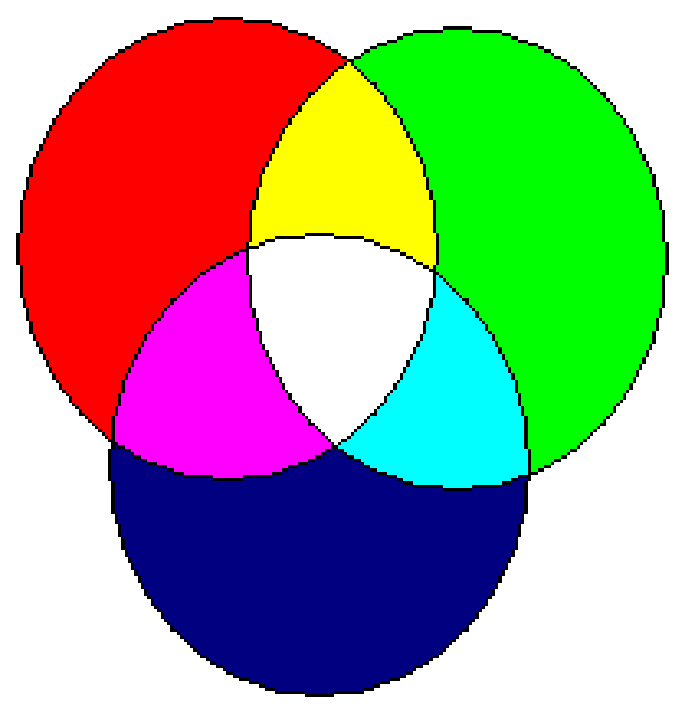

Figura 1: Esquema das cores da luz.

$\mathrm{Na}$ figura acima nota-se também que a interseção dos três círculos resulta a cor branca. 
- Fontes de Luz

\section{Fonte primária}

São os corpos que emitem luz própria.

Exemplo: as estrelas, carvão aceso, metal aquecido, lâmpadas, LED (fonte de luz monocromática), etc.

\section{Fonte secundária}

São os corpos que refletem luz de outros corpos de fonte de luz própria.

Exemplo: A Lua, planetas, a maioria dos corpos iluminados pela luz do Sol e/ou qualquer outra fonte de luz.

\section{Fonte pontual}

Quando a luz emitida pelo corpo pontual se espalha igualmente em todas as direções.

Exemplo: Luz vinda das estrelas, sinalizador de uma torre.

\section{Fonte extensa}

Quando a luz emitida pelo corpo chega ao observador em várias dimensões Exemplo: Lâmpada acesa de uma sala, farol de um carro, tela do computador.

\section{Fonte colimada}

São fontes de luz que se propaga em um ângulo de abertura muito pequeno, de maneira a se espalhar muito pouco.

Exemplo: Laser

As fontes podem emitir luz de dois tipos:

\section{Monocromática}

É a luz que possui uma só cor em sua essência, com um único comprimento de onda.

\section{Exemplo: Luz monocromática azul, vermelha, verde, etc.}

\section{Policromática}

É a luz que possui uma combinação de cores em sua essência, com vários comprimentos de ondas.

\section{Exemplo: Luz branca composta pela mistura de todas as cores}




\section{- As cores e o sentido da visão}

Sempre que se ilumina um objeto, parte dessa luz é absorvida pelo objeto, e a outra parte é refletida. A luz tem a propriedade de interagir com todos os objetos.

Por exemplo, ao iluminar um objeto com a luz branca, se enxergamos vermelho significa que esse objeto absorveu as luzes da cor azul e verde, e refletiu o vermelho. A luz vermelha chega aos nossos olhos e temos a impressão que a cor do objeto é vermelha.

$\mathrm{Na}$ figura abaixo é possível notar como enxergamos cada objeto quando iluminado por uma luz branca (composta pelas três cores primárias):

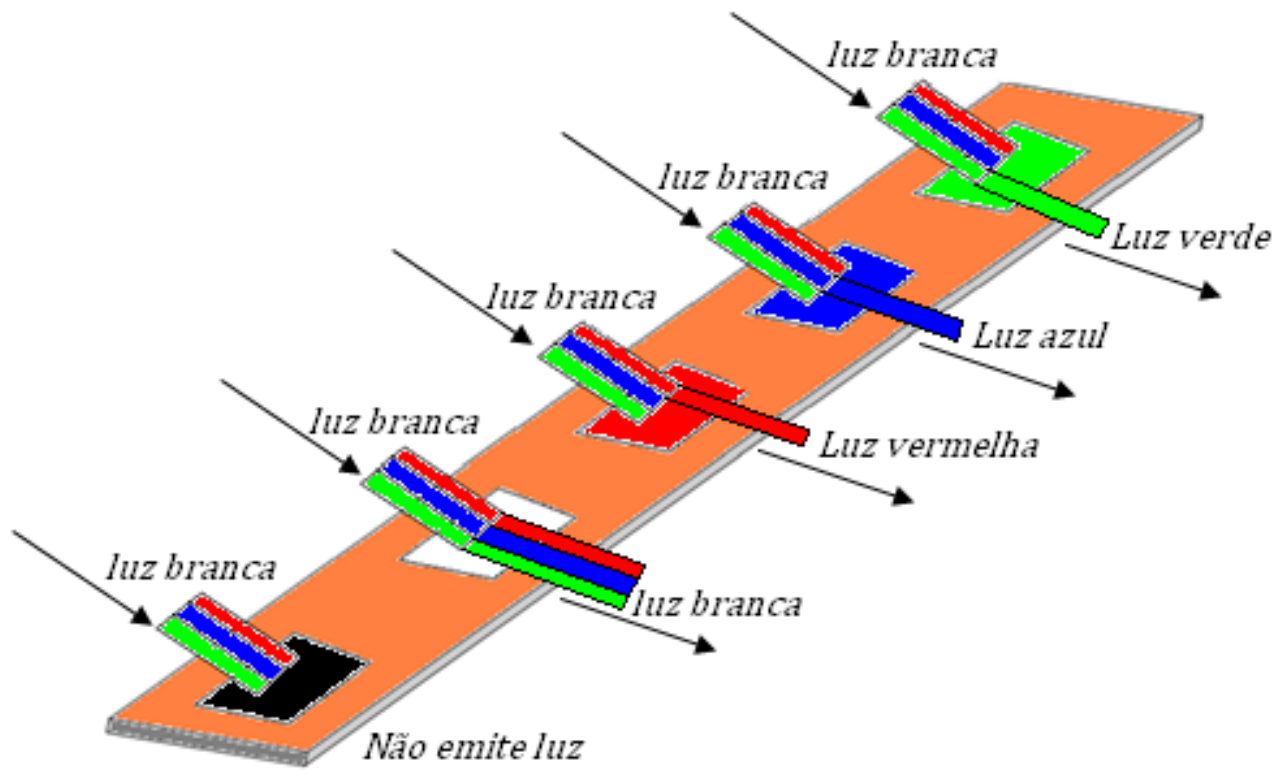

Figura 2: Objetos de cores diferentes e seu comportamento ao ser iluminado por uma luz policromática branca.

\section{- Propriedades da Luz}

\section{Trajetória retilínea}

Quando a luz está se propagando num meio transparente (como no ar, na água ou no vácuo) sua trajetória é retilínea, o que pode ser comprovado pela formação das sombras quando algum objeto intercepta a luz.

\section{Independência dos raios}

Quando um raio de luz atravessa o caminho de outro raio, as suas trajetórias não são desviadas, sendo assim os dois raios continuam seus caminhos, como se não tivesse acontecido nada. 


\section{Reversibilidade dos raios}

Quando se modifica a posição do observador com a fonte de luz, o caminho da luz não se modifica, ou seja, tanto de ida como de volta a trajetória da luz é sempre a mesma.

\section{- Câmara escura}

A câmara escura é um objeto em forma da caixa, com as paredes opacas e um pequeno orifício numa das paredes. A luz atravessa esse orifício, de modo a formar a imagem em seu interior, como mostra a figura 3 abaixo:

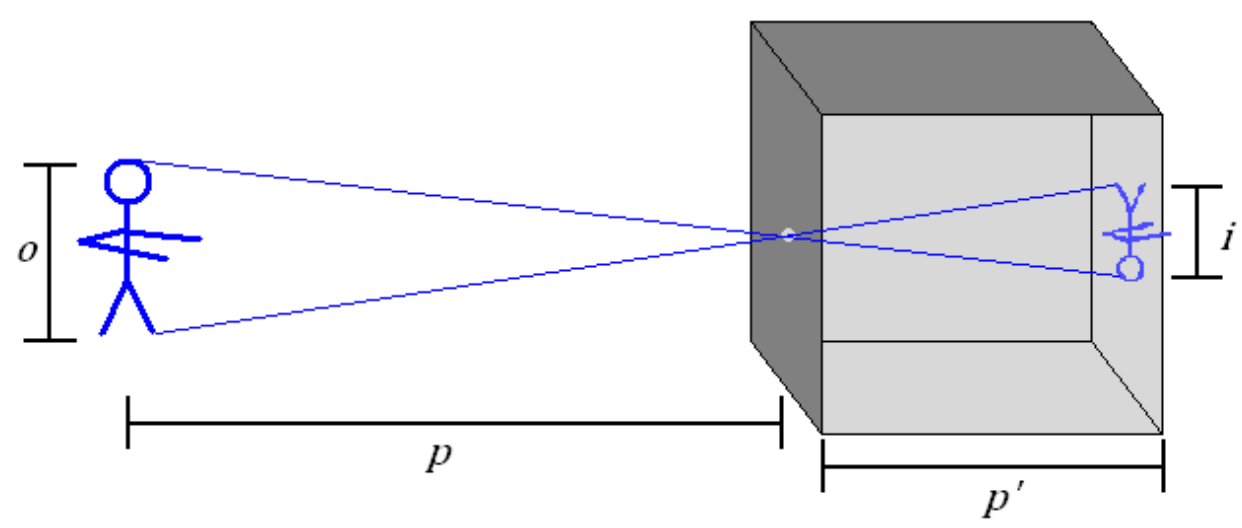

Figura 3: Esquema dos raios de luz e formação de imagem numa câmara escura.

Pode-se notar que o tamanho do objeto e o tamanho da imagem produzida no interior da câmara são proporcionais, e dependem ainda da distância do objeto a câmara e o tamanho da câmara escura, ou seja:

$$
\frac{o}{p}=\frac{i}{p^{\prime}}
$$

Equação 1: Câmara escura.

onde: $o$ é o tamanho do objeto

$i$ é o tamanho da imagem

$p$ é a distância do objeto a câmara

$p^{\prime}$ é a distância da imagem a câmara (comprimento da câmara)

\section{- Reflexão da Luz}

É a característica que a luz possui de retornar ao meio de incidência, quando incide numa superfície uniforme refletora. 
São exemplos de superfícies refletoras: a água num lago, uma placa metálica e um piso encerado.

Nos processos de reflexão, o ângulo de incidência é igual ao ângulo de reflexão. Como pode ser visto na figura abaixo:

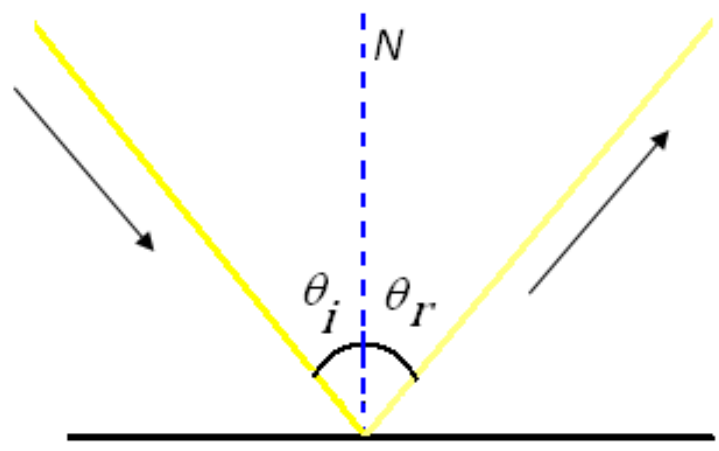

Figura 4: esquema representativo da reflexão da luz

Como pode ser visto na figura acima, o raio de luz vindo da esquerda incide na superfície com um ângulo de incidência $\theta_{i}$ em relação a reta normal a superfície do plano $N$, e reflete com ângulo de reflexão $\theta_{r}$. Desta maneira, pode-se afirmar que:

$$
\theta_{i}=\theta_{r}
$$

Equação 2: Lei de reflexão da luz

\section{- Construção de imagens nos espelhos}

A imagem é formada num espelho (superfície refletora) no ponto onde há o cruzamento dos raios refletidos.

Existem dois tipos de imagens:

- Real: quando os raios refletidos se convergem para um ponto.

- Virtual: quando refletidos se divergem, assim a imagem é formada pelo prolongamento dos raios, de modo a encontrar o ponto onde os dois raios se cruzam.

As imagens ainda podem ser classificadas como:

\begin{tabular}{|c|c|c|}
\hline Natureza & Direção & Tamanho \\
\hline Real & Direita & Ampliada \\
\hline Virtual & Invertida & Reduzida \\
\hline & & Mesmo tamanho \\
\hline
\end{tabular}


- Espelhos planos

Num espelho plano, a imagem formada é sempre virtual, direita e do mesmo tamanho, como pode ser vista na figura abaixo:

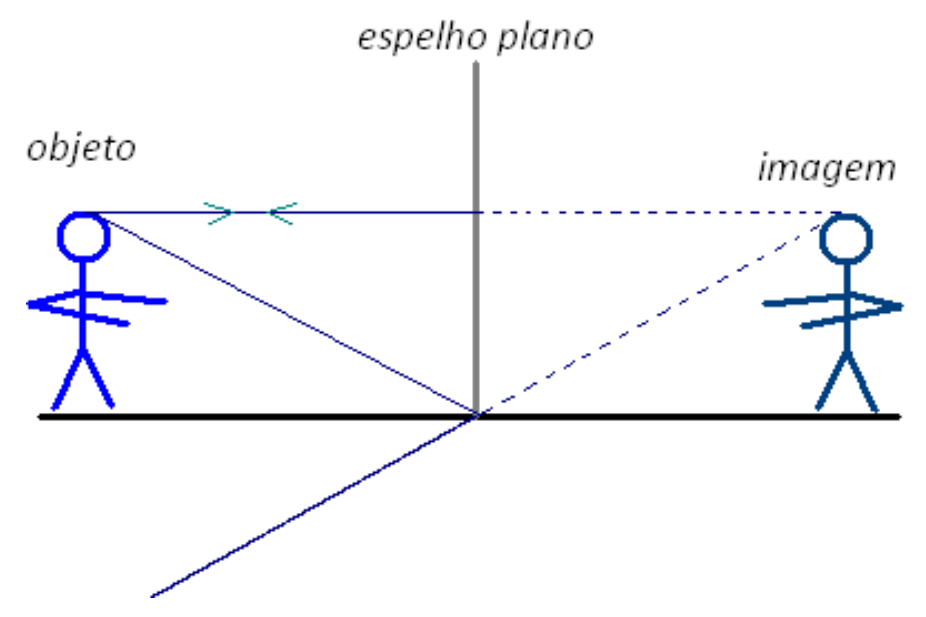

Figura 5: imagem formada num espelho plano.

- Espelhos esféricos

Os espelhos esféricos são originados a partir de uma esfera, conforme a figura abaixo:

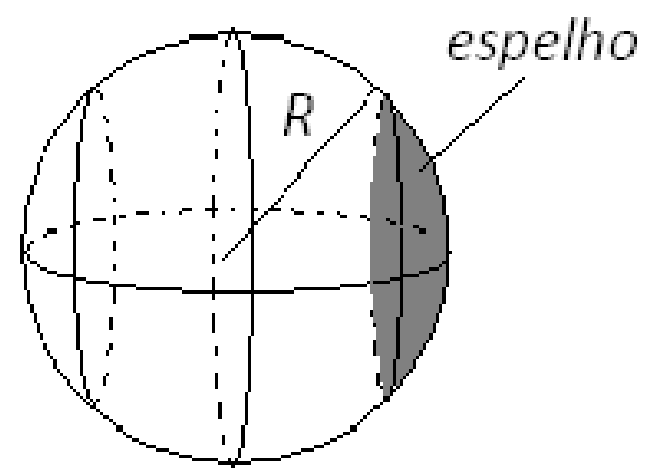

Figura 6: representação da origem de um espelho esférico

Os espelhos esféricos podem ser: côncavos ou convexos.

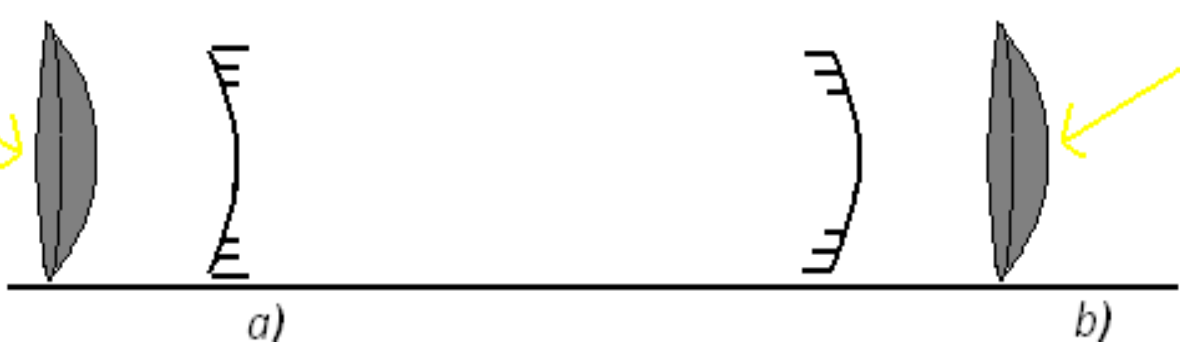

Figura 7: a) espelho côncavo e sua representação gráfica. b) espelho convexo e sua representação gráfica. 
Um espelho é côncavo é quando a parte refletora é a interna, e quando a parte refletora é a externa dizemos que o espelho é convexo.

Sendo assim podemos definir alguns elementos geométricos dos espelhos esféricos que são: centro de curvatura (C) em que o seu valor é dado pelo raio de curvatura da esfera que deu origem ao espelho, vértice $(\mathrm{V})$, eixo principal e foco (f). Nesse caso, pode-se definir o foco como sendo o ponto médio do segmento $\mathrm{CV}$, como na figura abaixo:
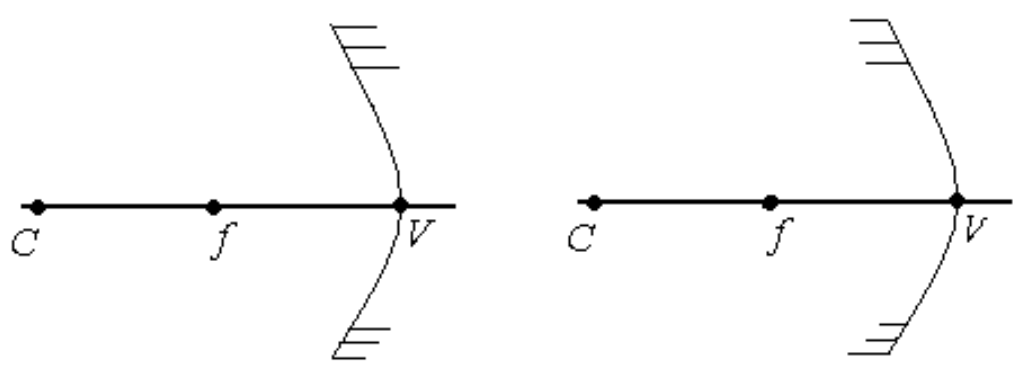

Figura 8: componentes geométricos dos espelhos esféricos. A direta o espelho côncavo e a esquerda o espelho convexo.

Pela figura 8 acima, nota-se que o vértice, o foco e o centro de curvatura estão no mesmo plano óptico. Podemos ainda pode-se definir o foco como sendo o ponto médio do segmento $C V$, ou seja:

$$
f=\frac{C}{2}
$$

Equação 3: relação foco e raio de curvatura.

De posse desses conceitos, podemos agora definir o comportamento dos raios de luz ao incidir em cada espelho, e explicarmos como há a formação das imagens. assim:

$\checkmark$ Todo raio de luz que passa pelo centro de curvatura e incide em um espelho esférico reflete sobre si mesmo.

$\checkmark$ Todo raio de luz que incide paralelamente ao espelho esférico reflete-se passando pelo foco, assim como todo raio de luz que passa pelo foco e incide no espelho côncavo reflete-se paralelo ao eixo principal.

$\checkmark$ Todo raio de luz que incide no vértice de um espelho esférico reflete com o mesmo ângulo de incidência em relação ao eixo principal.

$\mathrm{Na}$ figura 9 abaixo se observa o comportamento dos raios de luz ao incidirem num espelho esférico côncavo. 

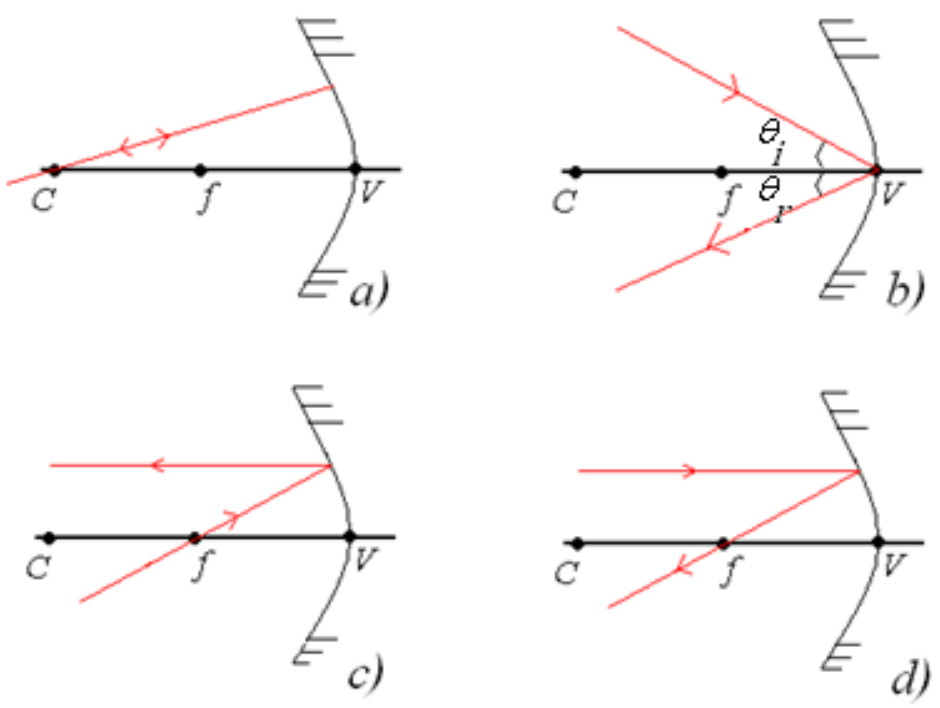

Figura 9: representação dos raios de luz num espelho côncavo. a) o raio que passa por $C e$ incide no espelho reflete sobre si. b) o raio que incide no vértice num ângulo $\iota$ reflete com ângulo $\theta$. c) um raio que passa pelo foco e incide espelho reflete paralelo ao eixo óptico. d) um raio paralelo ao eixo óptico que incide no espelho reflete de tal modo a passar pelo foco.

De maneira análoga a figura 9, a figura 10 representa o comportamento dos raios de luz ao incidirem num espelho convexo.

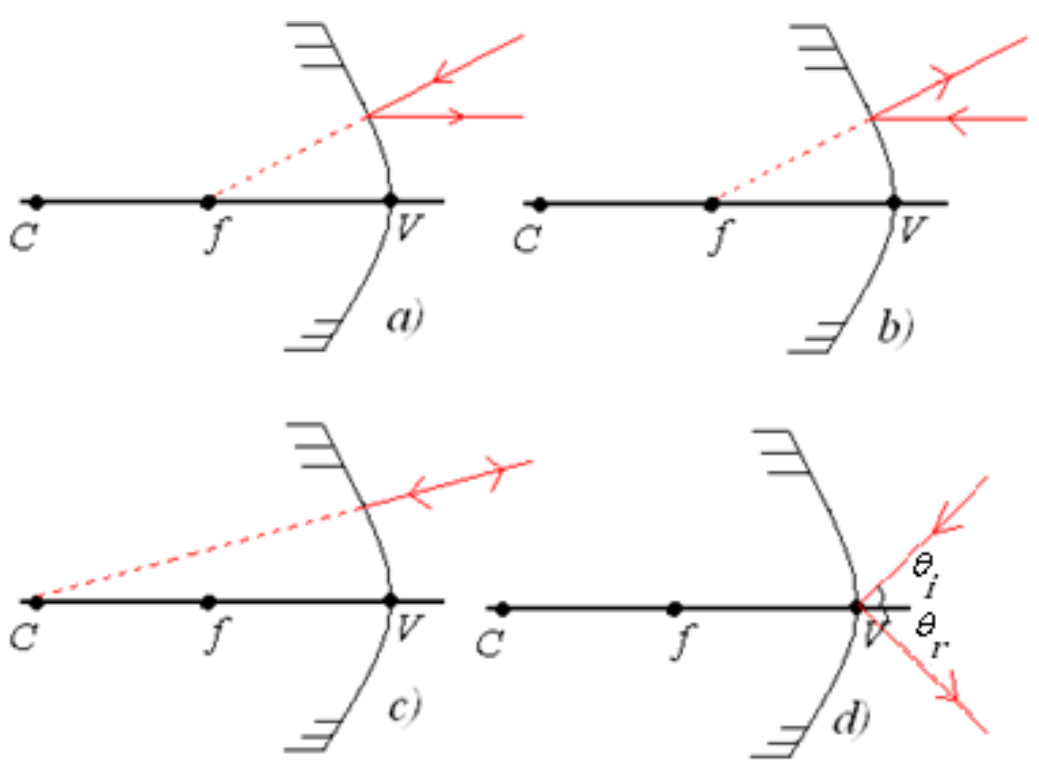

Figura 10: representação dos raios de luz num espelho convexo. a) o raio que incide na direção do foco reflete paralelamente ao eixo óptico. b) o raio que incide paralelo ao eixo óptico reflete

na direção do foco e em sentido contrário. c) o raio que incide na direção do centro de curvatura reflete em sentido contrário. d) o raio que incide no vértice num ângulo $\mathrm{l}$ reflete com ângulo $\theta$.

Assim, quando objeto está situado no mesmo eixo óptico do espelho, podemos utilizar dois raios de luz partindo de um mesmo ponto do para deduzir a representação da imagem deste objeto no espelho, nas diversas situações representadas a seguir. 
1. Caso: Objeto posicionado depois do centro de curvatura

A imagem será real, invertida e reduzida, como o esquema abaixo:

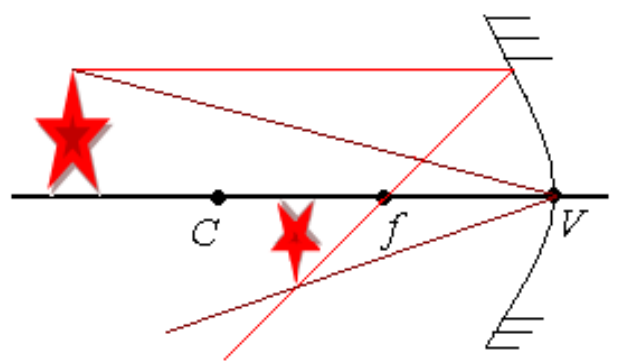

Figura 11: representação da imagem obtida num espelho côncavo com objeto posicionado depois do centro de curvatura do espelho.

\section{Caso: Objeto posicionado no centro de curvatura}

A imagem será real, invertida e mesmo tamanho, como o esquema abaixo:

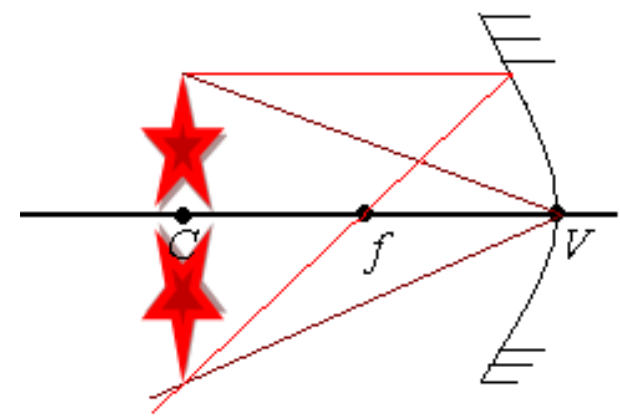

Figura 12: representação da imagem obtida num espelho côncavo com objeto posicionado no centro de curvatura do espelho.

3. Caso: Objeto posicionado entre o centro de curvatura e o foco

A imagem será real, invertida e ampliada, como o esquema abaixo:

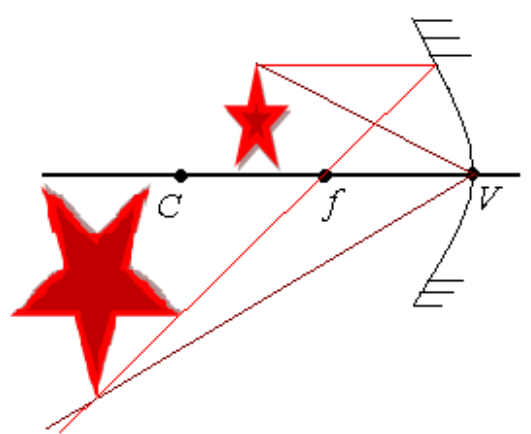

Figura 13: representação da imagem obtida num espelho côncavo com objeto posicionado entre o centro de curvatura e o foco do espelho. 


\section{Caso: Objeto posicionado entre no foco}

A imagem será Imprópria, pois os raios ao refletidos no espelho são paralelos entre si, e a imagem se formará no infinito como o esquema abaixo:

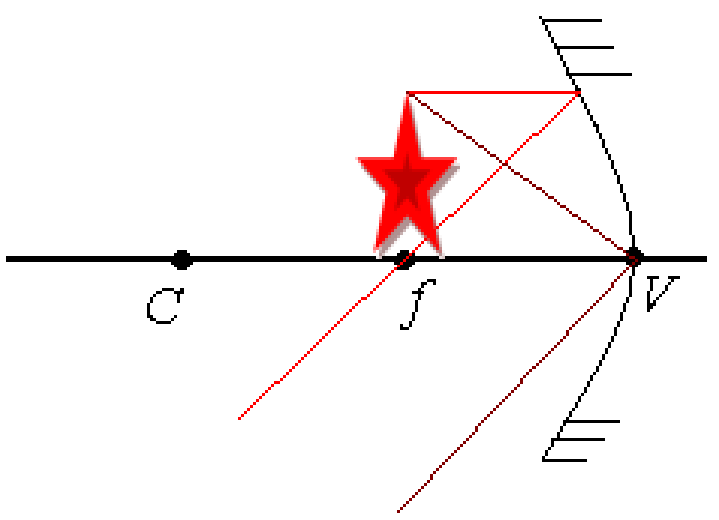

Figura 14: representação da imagem obtida num espelho côncavo com objeto posicionado no foco do espelho

\section{Caso: Objeto posicionado entre o centro de curvatura e o foco}

A imagem será virtual (formada pelo prolongamento dos raios), direita e ampliada, como o esquema abaixo:

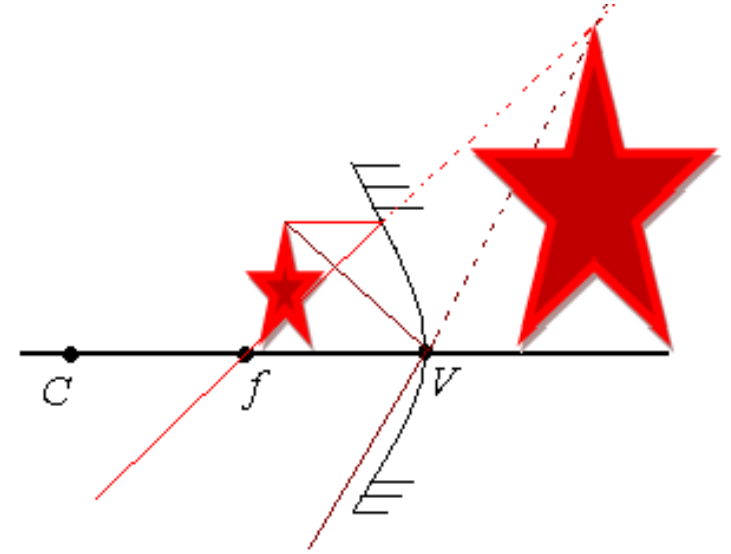

Figura 15: representação da imagem obtida num espelho côncavo com objeto posicionado antes do foco do espelho

\section{- Espelhos convexos}

Caso único: Independente da distância do objeto ao espelho, a imagem sempre será Virtual, direita e reduzida, como mostra a figura abaixo: 


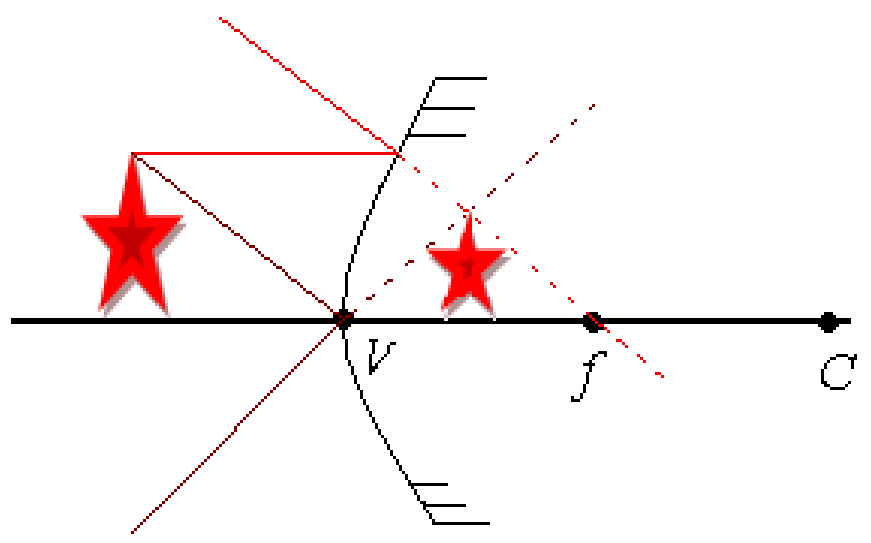

Figura 16: representação da imagem num espelho convexo independente da posição do objeto - Equação de Gauss

A Equação de Gauss relaciona a distância focal com a posição do objeto e a posição da imagem, e assim deduzir de forma analítica a imagem de um objeto refletida em um espelho esférico, da seguinte maneira:

$$
\frac{1}{f}=\frac{1}{p}+\frac{1}{p^{\prime}}
$$

Equação 4: Equação de Gauss

Onde: $f \rightarrow$ foco do espelho

$p \rightarrow$ distância do objeto ao espelho

$p^{\prime} \rightarrow$ distância da imagem ao espelho

\section{- Aumento linear}

Aumento linear é a proporção entre a altura da imagem e a altura do objeto formada no espelho, ou ainda a razão entre a distância da imagem pela distância do objeto a lente.

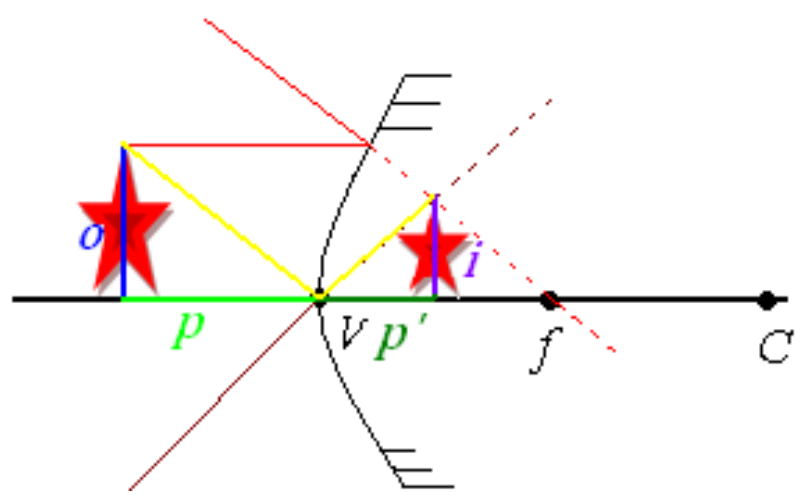

Figura 17: esquema da relação entre imagem e objeto num espelho esférico. 
Como pode ser visto na figura 17 acima, $o$ e $p$ se relacionam por semelhança de triângulos com i e p', ou seja:

$$
\frac{o}{p}=\frac{i}{p^{\prime}} \rightarrow \frac{i}{o}=\frac{p \prime}{p}=A
$$

onde: $A \rightarrow$ aumento linear transversal

\section{- Refração da Luz}

Quando se observa um objeto através de uma Luneta, notamos sua imagem mais próxima.

Isso é possível por que dentro desse instrumento há um objeto chamado lente.

As lentes são constituídas de dois meios transparentes e tem propriedade de desviar os raios de luz.

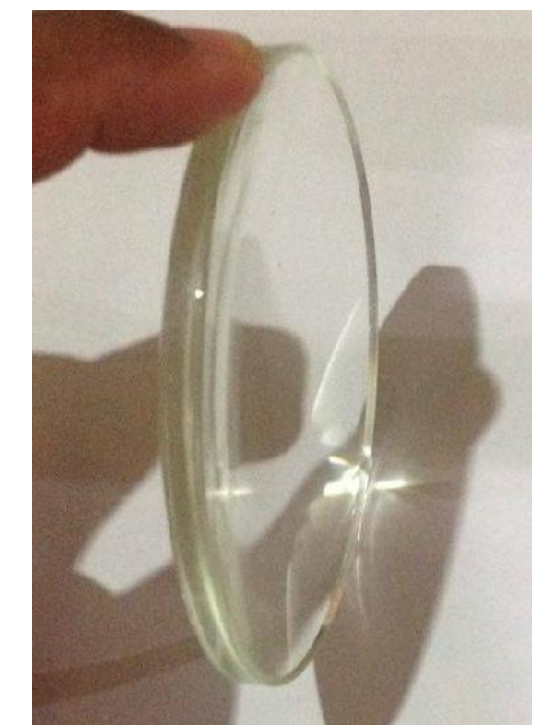

Figura 18: Foto de uma lente convergente

Ao atravessar de um meio a outro, a luz sofre desvio. Esse fenômeno é chamado de refração.

Dessa forma, ao passar do ar para a água notamos uma "quebra no raio luminoso", como pode ser visto na figura abaixo: 


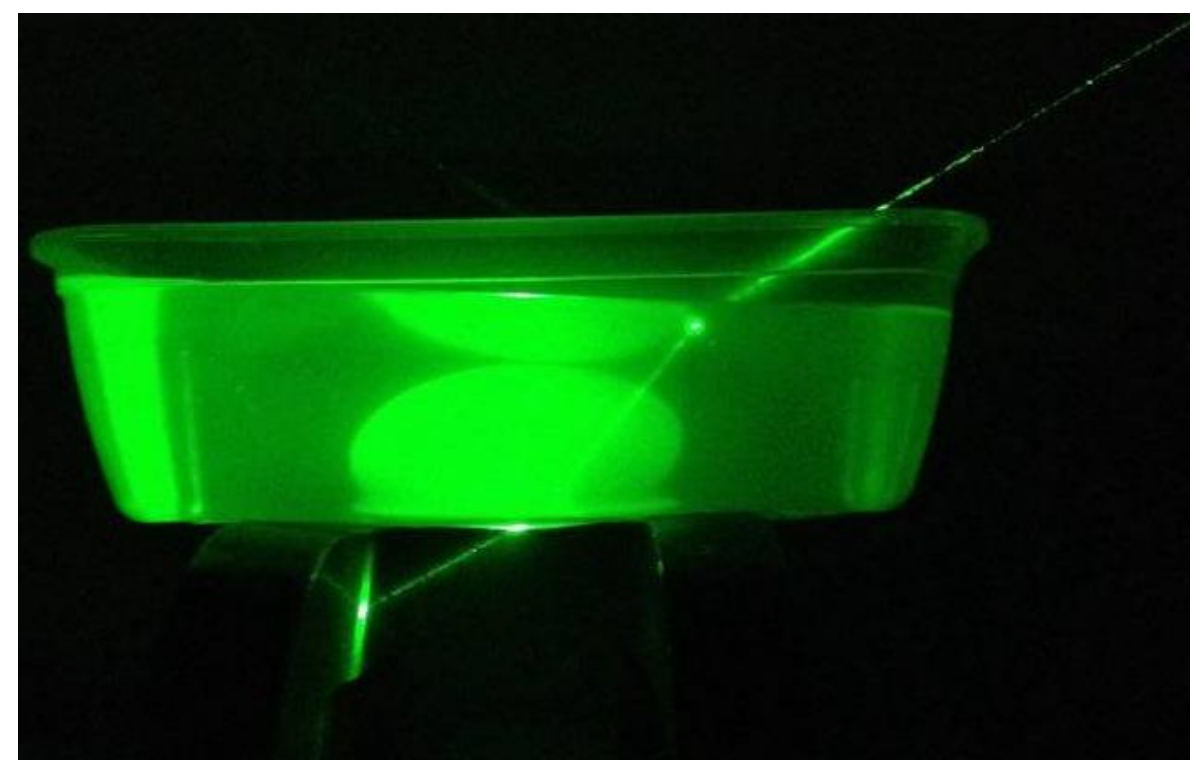

Figura 19: Foto da luz de um laser atravessando uma bacia com água.

É possível notar na figura acima que ao chegar na água, a luz "quebra" seu caminho e ao sair da bacia a luz volta desviar seu caminho novamente.

A lente da figura 18 também é capaz de desviar a trajetória da luz.

Assim, todo meio translúcido é capaz de desviar a trajetória da luz, uns desviando mais e outros desviando menos, essa característica se chama índice de refração do meio.

$\mathrm{Na}$ refração além da trajetória da luz ser alterada, a sua velocidade também é alterada.

Defini-se o índice de refração do meio como sendo a razão entre a velocidade da luz no vácuo com a velocidade da luz no meio, ou seja:

$$
n=\frac{c}{v}
$$

Equação 5: definição de índice de refração

Onde: $n \rightarrow$ índice de refração

$c \rightarrow$ velocidade da luz no vácuo

$V \rightarrow$ velocidade da luz no meio

A luz branca ao sofrer refração dispersas as cores: decomposição da luz.

O arco-íris é um exemplo de dispersão da luz. A luz vinda do sol, ao passar por gotículas de água na atmosfera, se decompõe em diversas cores formando o arco-íris. 
Se usarmos um prisma óptico será possível observar a decomposição da luz de uma lanterna de um aparelho de celular, como na figura abaixo.

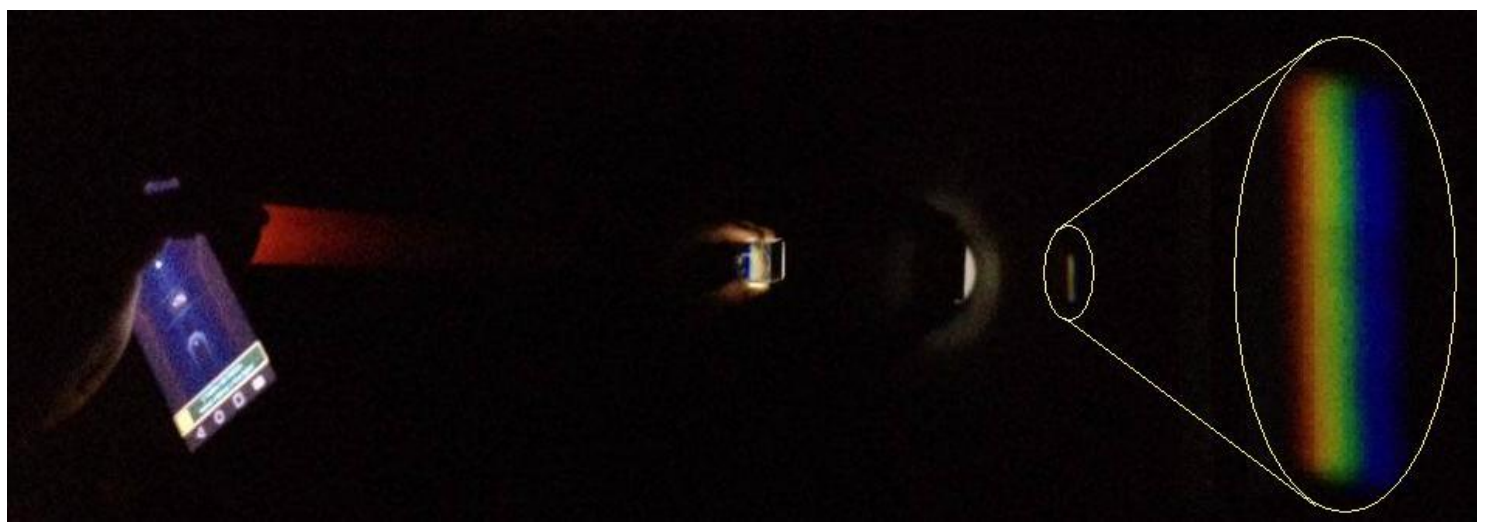

Figura 20. Ao incidir a luz de uma lanterna de celular num prisma, há a decomposição da luz.

\section{Reflexão interna total}

Na figura 18 é possível notar que uma parte da luz de laser sofre reflexão, pois a superfície da água também age como um espelho.

Se aumentarmos a inclinação da luz será possível observar que num determinado momento a luz deixará de sofre refração e passará apenas reflexão, o que é chamado de reflexão interna total.

Num prisma de $45^{\circ}$, é possível observar a reflexão interna total, onde os raios de luz são refratados em $90^{\circ}$. Na figura abaixo temos o prisma diagonal com ângulo de $90^{\circ}$ da luneta, que visualizar as imagens com mais conforto 0 instrumento de observação.

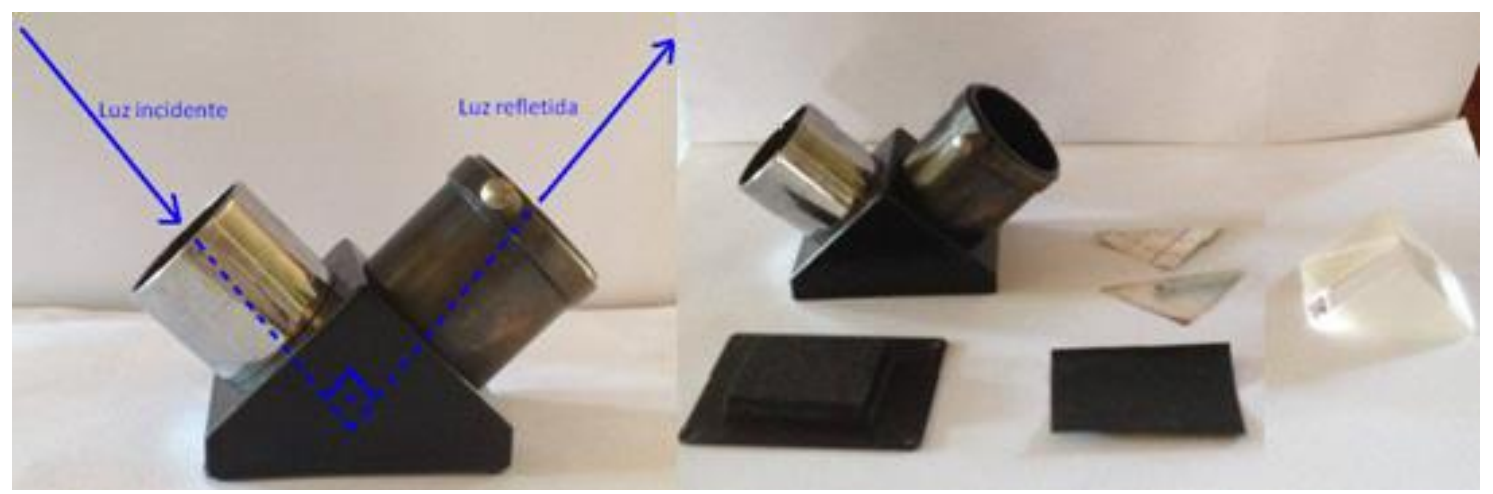

Figura 21: Foto do prisma diagonal com ângulo de $90^{\circ}$ da luneta a esquerda e a direita 0 instrumento desmontado.

\section{- Construção de imagens nas lentes}

As lentes, assim como os espelhos são originadas a partir de uma esfera (com esquema semelhante ao da figura 6). 
As lentes também são constituídas pelos elementos geométricos: centro de curvatura $(C)$ em que o seu valor é dado pelo raio de curvatura da esfera que deu origem ao espelho, vértice $(\mathrm{V})$, eixo principal e foco (f).

Existem vários tipos de lentes, como é mostrado na figura 22 abaixo:

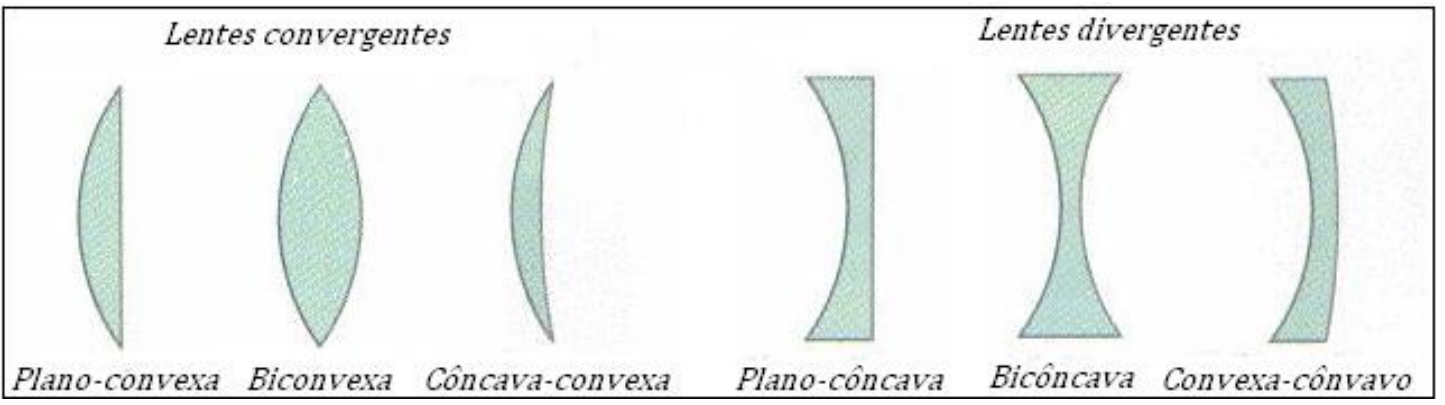

Figura 22: Formatos das lente. Retirado de http://curso2012fisica.blogspot.com.br/p/4-anoreflexion-y-refraccion-de-la-luz.htm/ com adaptações.

As lentes podem ser classificadas quanto a forma de desviar os raios de luz: convergentes ou divergentes, como mostra a figura 22 acima.

A representação das lentes convergentes e divergentes é indicada na figura 23 abaixo:
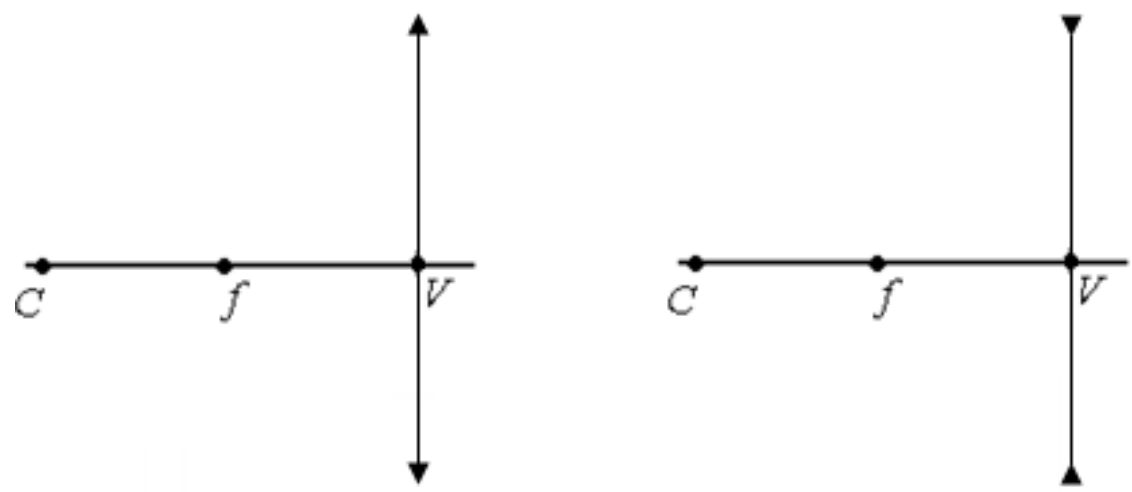

Figura 23: componentes geométricos das lentes. A direta a lente convergente e a esquerda lente divergente.

Assim como nos espelhos, podemos representar a imagem formada quando objeto está situado no mesmo eixo óptico da lente com apenas dois raios luminosos.

Os raios de luz se comportam nas lentes semelhantemente aos espelhos, sendo que os espelhos refletem os raios luminosos enquanto as lentes refratam esses raios.

Dessa maneira, podemos utilizar dois raios de luz partindo de um mesmo ponto do para deduzir a representação da imagem deste objeto nas lentes, nas situações representadas a seguir. 
- Lentes convergentes

1. Caso: Objeto posicionado depois do centro de curvatura

A imagem será real, invertida e reduzida, como o esquema abaixo:

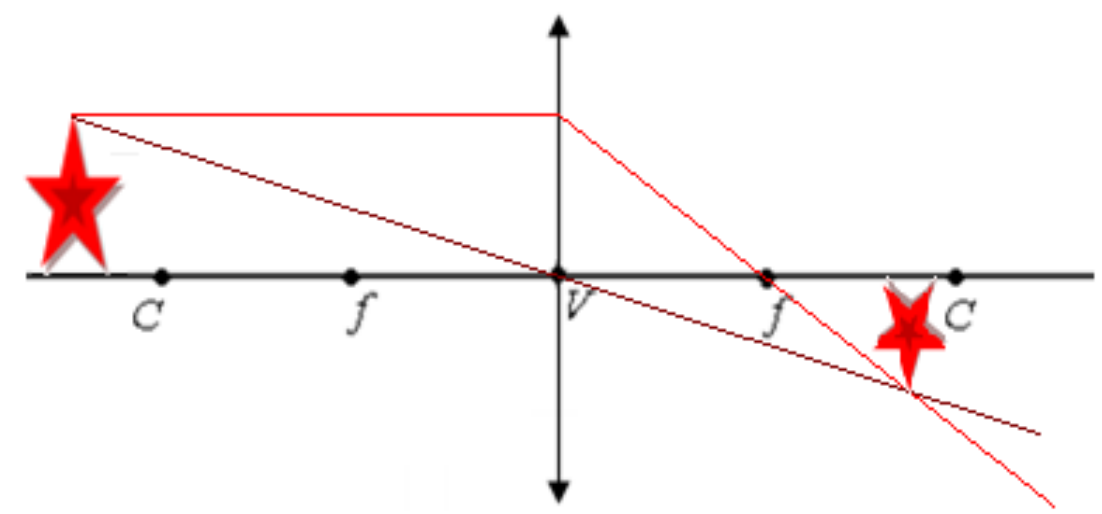

Figura 24: representação da imagem obtida numa lente convergente com objeto posicionado depois do centro de curvatura da lente.

\section{Caso: Objeto posicionado no centro de curvatura}

A imagem será real, invertida e mesmo tamanho, como o esquema abaixo:

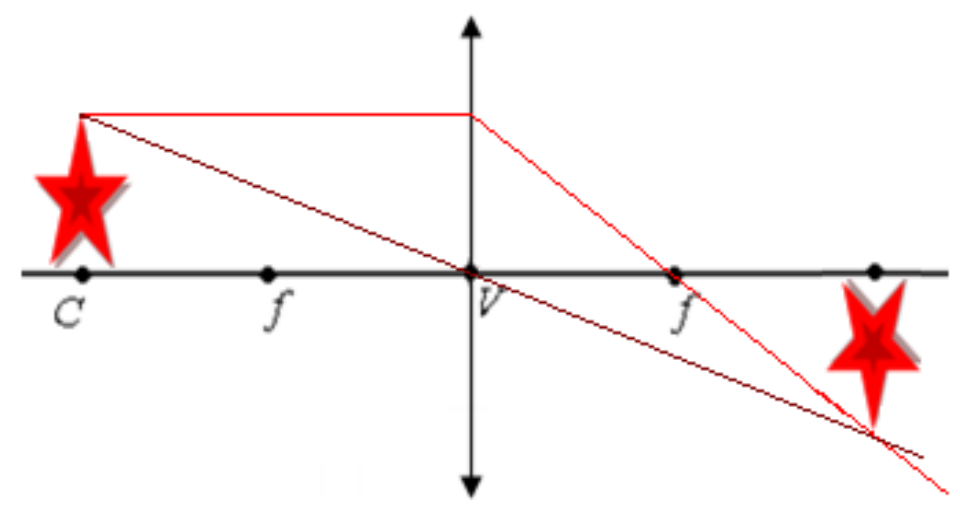

Figura 25: representação da imagem obtida numa lente convergente com objeto pooklsicionado no centro de curvatura dessa lente.

\section{Caso: Objeto posicionado entre o centro de curvatura e o foco}

A imagem será real, invertida e ampliada, como o esquema abaixo: 


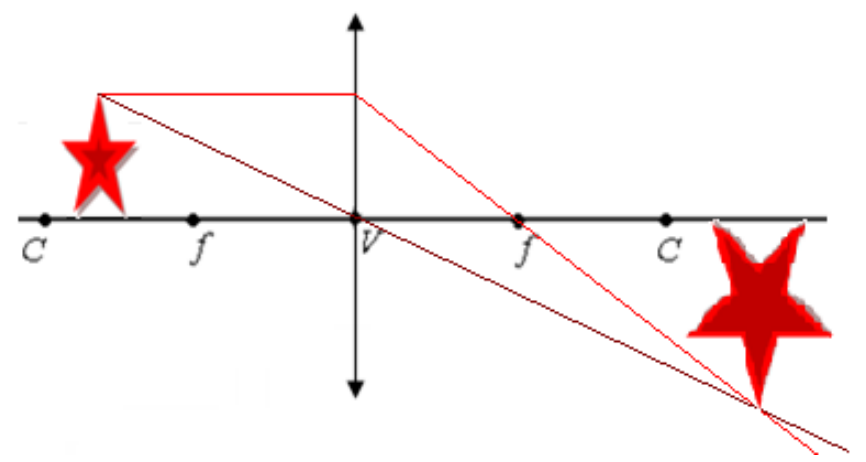

Figura 26: representação da imagem obtida numa lente convergente com objeto posicionado entre o centro de curvatura e o foco dessa lente.

\section{Caso: Objeto posicionado no foco}

A imagem será Imprópria, pois os raios ao refratados na lente são paralelos entre si, e a imagem se formará no infinito como o esquema abaixo:

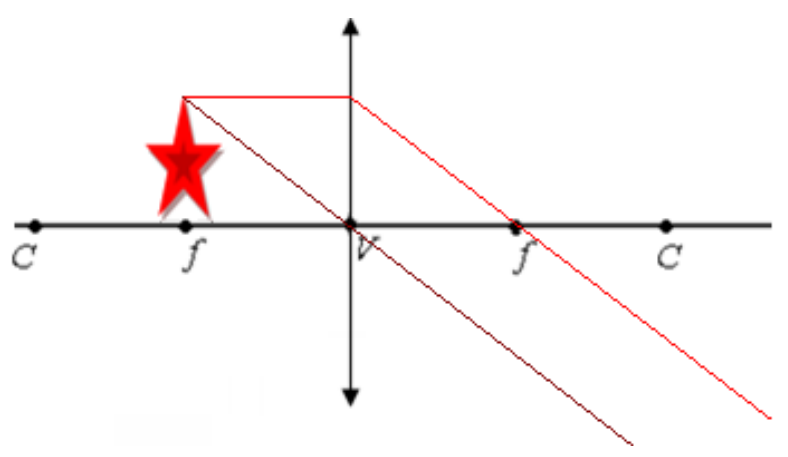

Figura 27: representação da imagem obtida numa lente convergente com objeto posicionado no foco dessa lente.

5. Caso: Objeto posicionado entre o centro de curvatura e o foco

A imagem será virtual (formada pelo prolongamento dos raios), direita e ampliada, como o esquema abaixo:

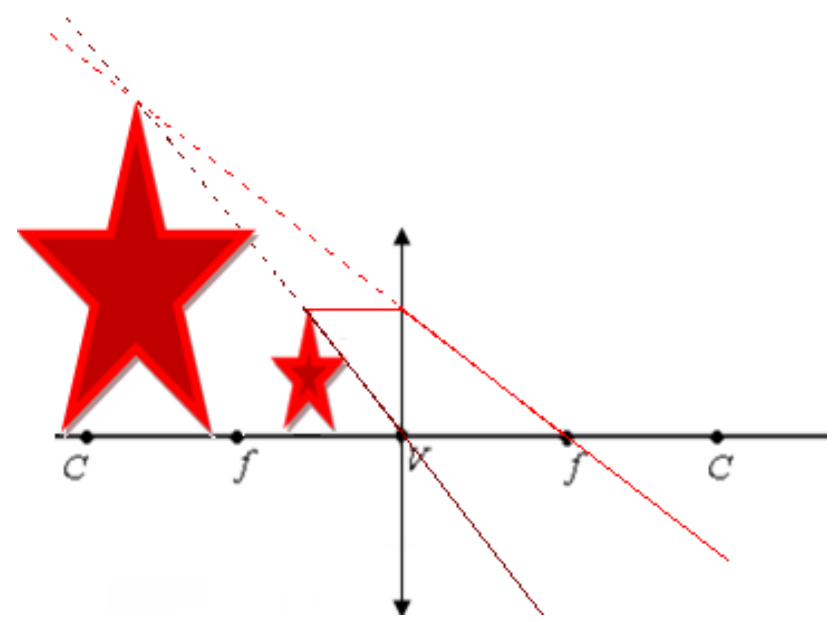

Figura 28: representação da imagem obtida numa lente convergente com objeto posicionado antes do foco dessa lente. 


\section{- Lentes divergentes}

Caso único: Independente da distância do objeto a lente, a imagem sempre será Virtual, direita e reduzida, como mostra a figura abaixo:

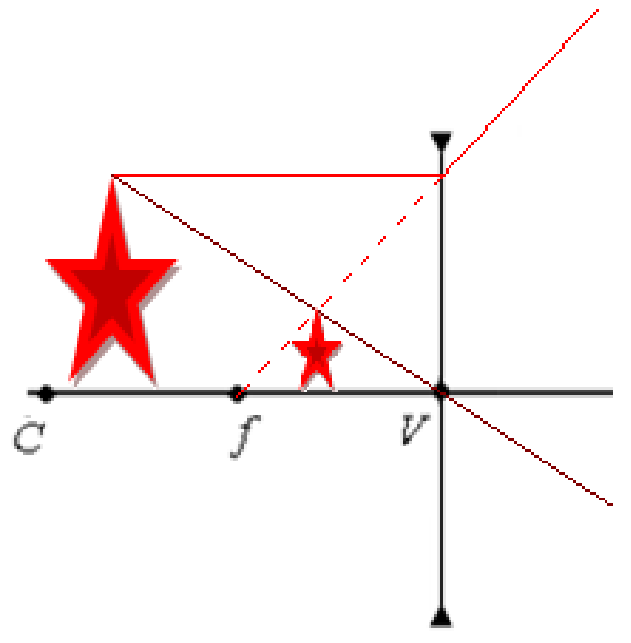

Figura 29: representação da imagem numa lente divergente independente da posição do objeto

Assim como nos espelhos esféricos, a equação de Gauss relaciona à distância focal com a posição do objeto e a posição da imagem, conforme a equação 4 já apresentada na pagina 10, essa equação é também conhecida como a equação dos fabricantes de lentes.

\section{- Associação de lentes}

Podem-se usar duas ou mais lentes em associação para se obter alguns instrumentos ópticos, como a luneta galileana.

Em associação de lentes separadas temos dois casos:

\section{Caso: Convergente-divergente}

Associamos uma lente convergente e uma lente divergente no instrumento óptico como no esquema a seguir:

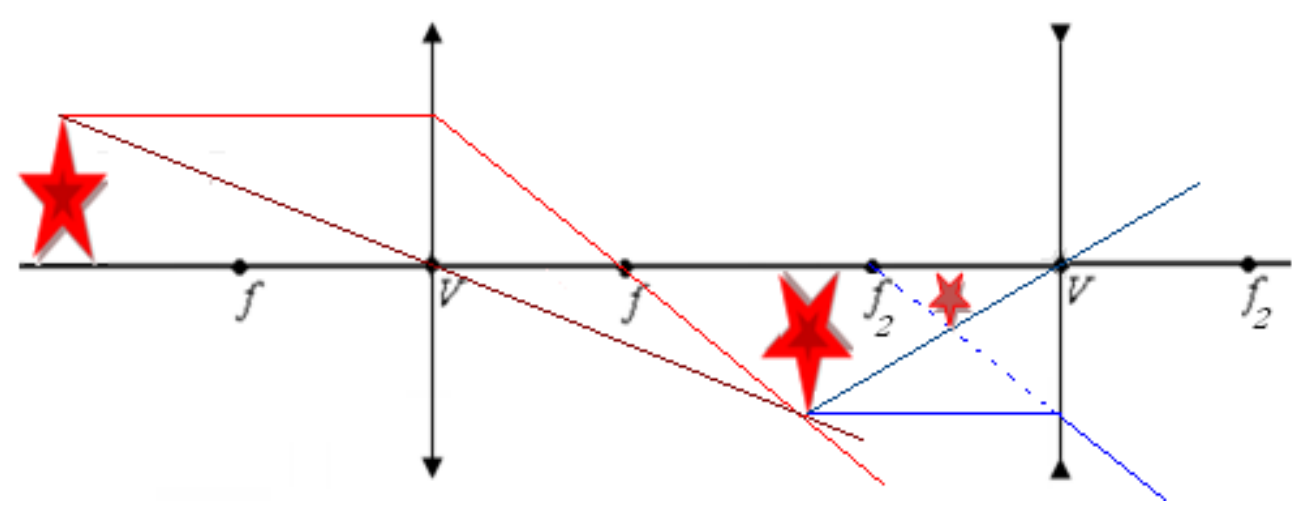

Figura 30: representação da imagem numa associação de lentes convergente-divergente. 


\section{Caso: Convergente-convergente}

Associamos duas lentes convergentes no instrumento óptico como no esquema a seguir:

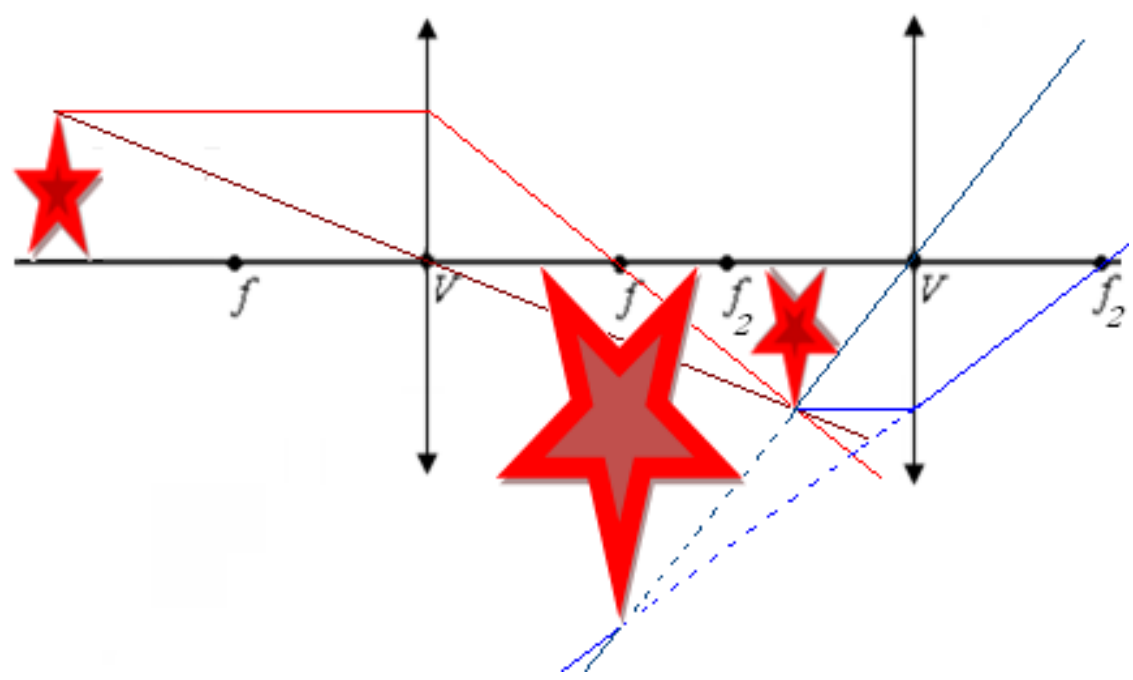

Figura 31: representação da imagem numa associação de lentes convergente-convergente.

\section{- Luneta Astronômica}

Também conhecida como telescópio refrator, a luneta é formada da associação de duas lentes convergentes.

Para visualizar objetos como Lua e outros planetas, por exemplo, que estão a uma distância muito grande, usamos o esquema a seguir:

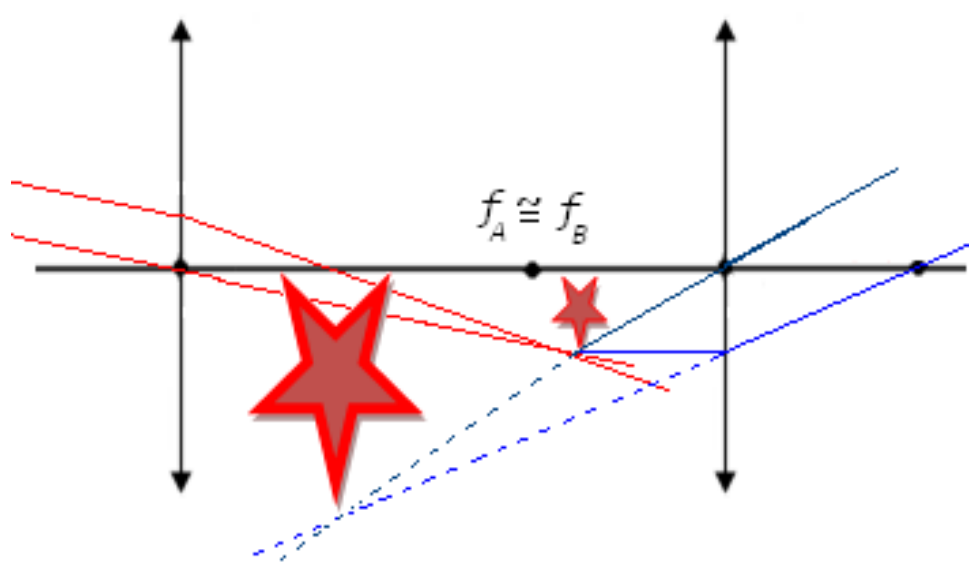

Figura 32: representação do funcionamento da luneta astronômica.

\section{Guia para montagem da Luneta.}

Para construção de luneta com lentes de óculos, recomenda-se usar lentes convergentes de $+1,25$ graus a objetiva $e+4$ graus a ocular (facilmente encomendado nas lojas de ópticas). 
As lentes devem ser fabricadas de modo a se encaixar numa junção de tubo de esgoto de 50 a objetiva, e numa redução de tubo de água de $40 \times 32$ a ocular.

Com auxílio de um aparelho de celular, ou mesmo de uma lâmpada (comum, lâmpada acesa da sala de aula) conferir a distância focal das lentes. Caso esteja usando as lentes recomendada, essas medidas estarão em torno de $65 \mathrm{~cm}$ a $85 \mathrm{~cm}$ de foco para a lente objetiva, e entre $15 \mathrm{~cm}$ e $25 \mathrm{~cm}$ para a lente ocular.

Sendo assim, é recomenda cortar o tubo de esgoto de 50 , com $50 \mathrm{~cm}$ de comprimento, assim como o tubo de esgoto de 40 , com $50 \mathrm{~cm}$.

É importante que o cano de 40 possa transpassar ajustadamente pelo tubo de 50 (para poder focalizar as duas lente e obter melhor visualização na luneta), para isso corte alguns "anéis" de tubo de 40 , deixando separado, conforme a figura abaixo:
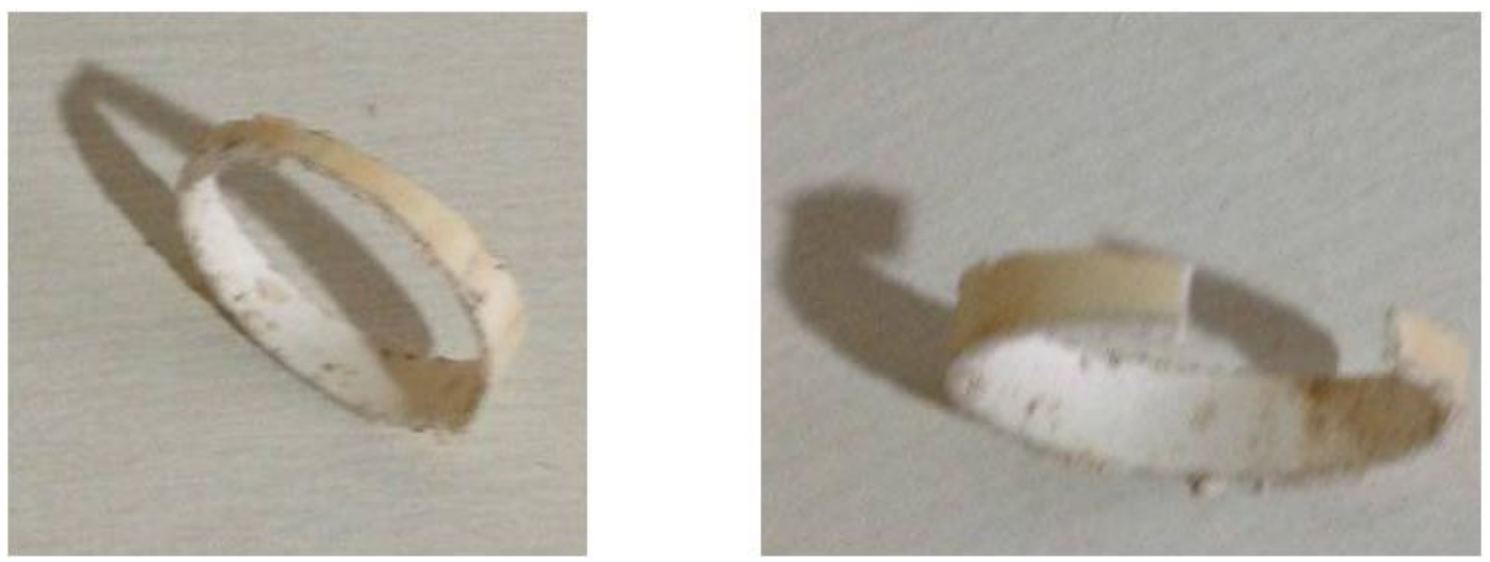

Figura 33: a esquerda foto do anel de tubo de 40. A direita o mesmo anel agora aberto

Os anéis serviram para ajustar o cano de 40 a passar pelo cano de 50 , sem folga. Para isso, é preciso colar dois anéis ao cano de 40, um em cima do outro. Conforme a figura abaixo:

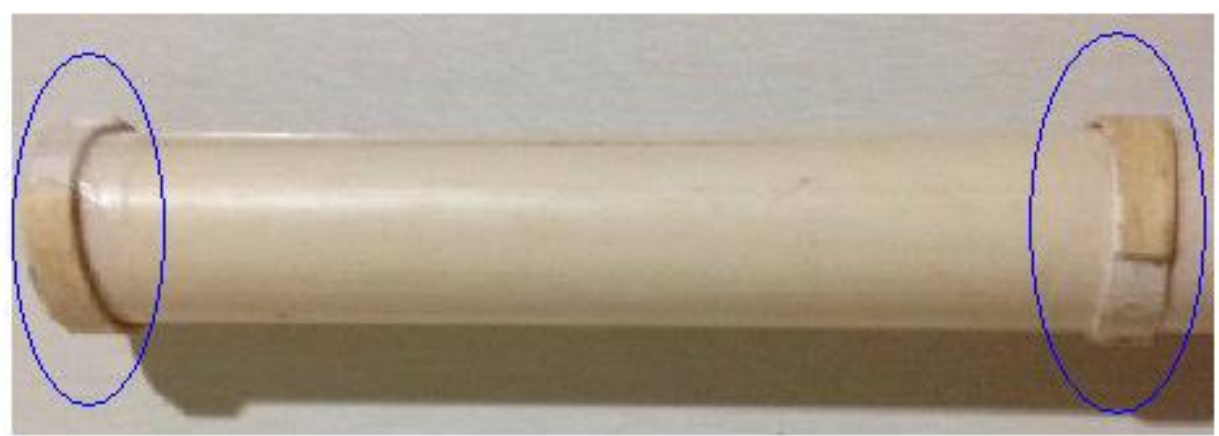

Figura 34: Anéis de 40 fixados ao tubo de 40. 
Caso ainda haja mais alguma folga, passe uma fita isolante nos anéis, 0 que ajudará a melhorar no ajuste, como na figura abaixo:

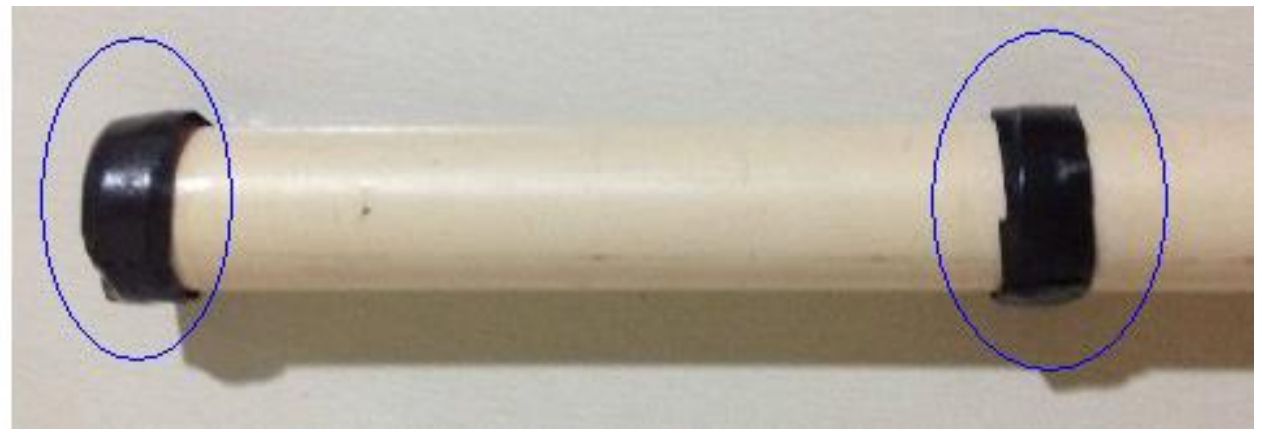

Figura 35: fita ajudará no ajuste entre o cano de 50 e de 40.

Com os dois canos já preparados, coloque a lente objetiva na junção de 50 , de modo a fixá-la com o tubo de 50, conforme a figura abaixo:

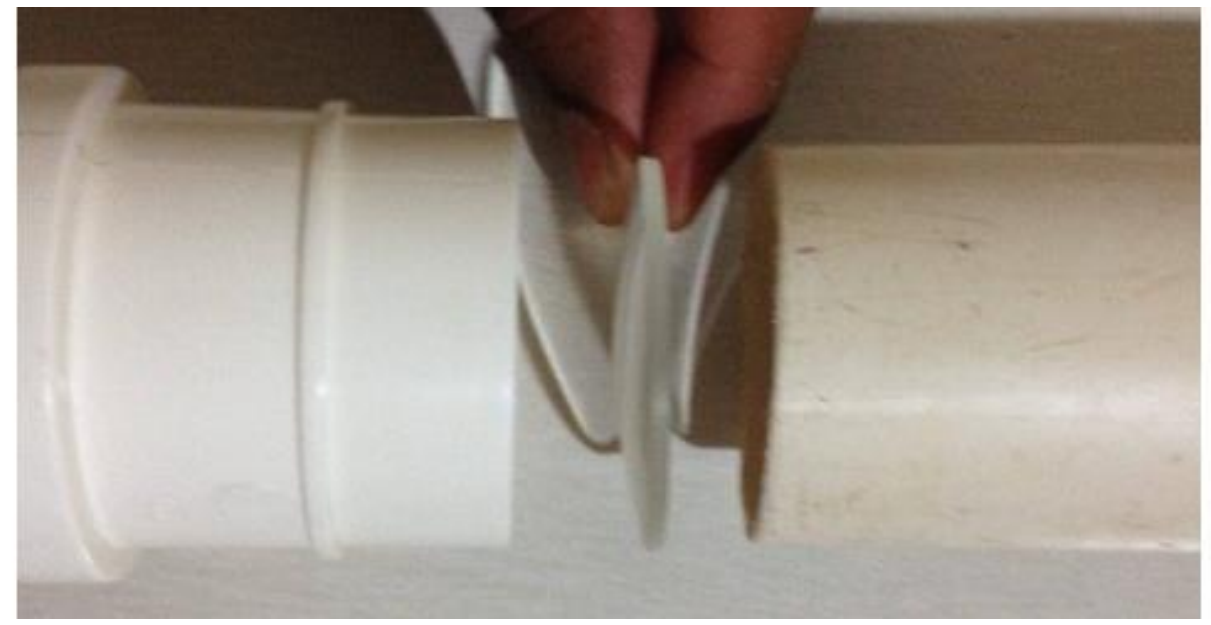

Figura 36: encaixe da lente objetiva no tubo de 50.

Da mesma maneira, faremos com a lente ocular, encaixando-a na redução de $32 \times 50$, como na figura abaixo:

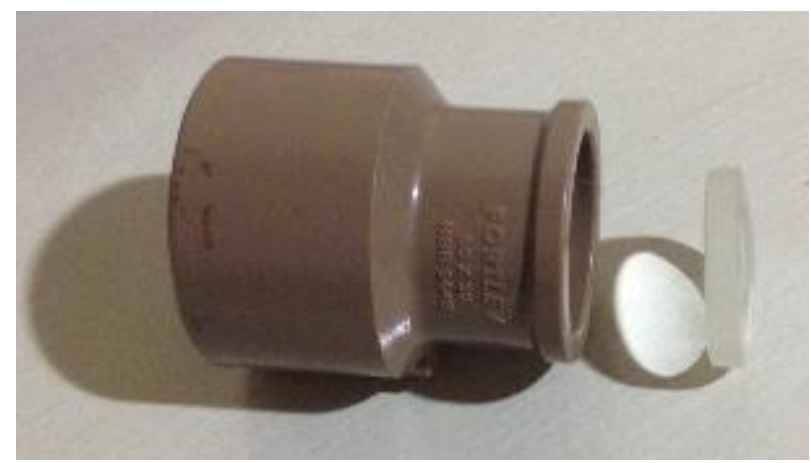

Figura 37: encaixe da lente ocular na redução de 32 × 50 
A próxima etapa é encaixar a redução no tubo de 40 . Mais uma vez, cortam-se os anéis e separa-os conforme a figura 33, mas ao invés de colar um em cima do outro, dessa vez cola-se um ao lado do outro (os tubos de água são ligeiramente mais delgado que os tubos de esgoto) em uma das extremidades do tubo, conforme a figura abaixo:
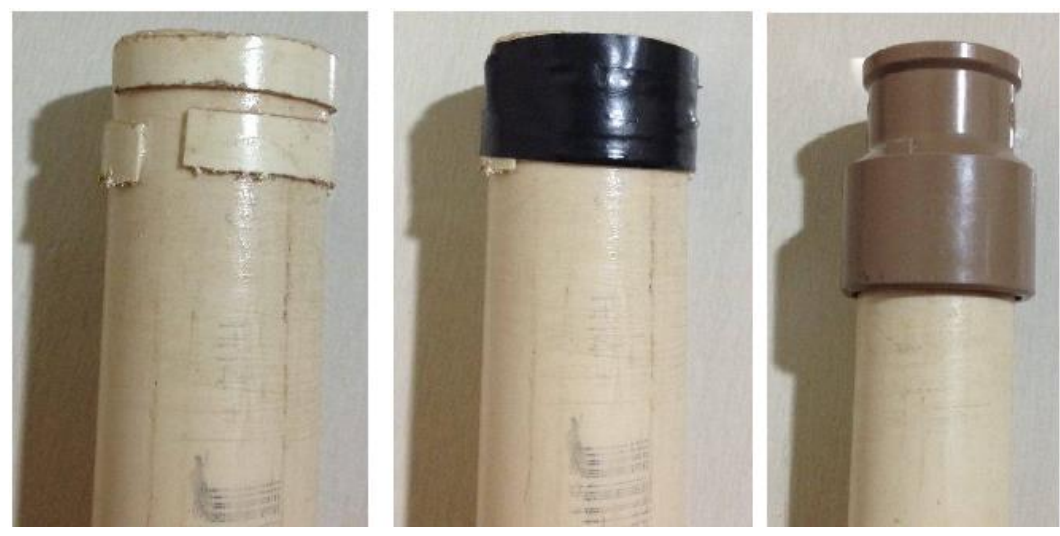

Figura 38: montagem d final do tubo de 40.

Outra vez, passa-se a fita isolante de modo a ajustar ainda mais o encaixe entre essas duas peças. Pode-se usar uma junção de 40 para unir as duas partes.

Assim, os dois tubos montados ficarão como na figura abaixo:
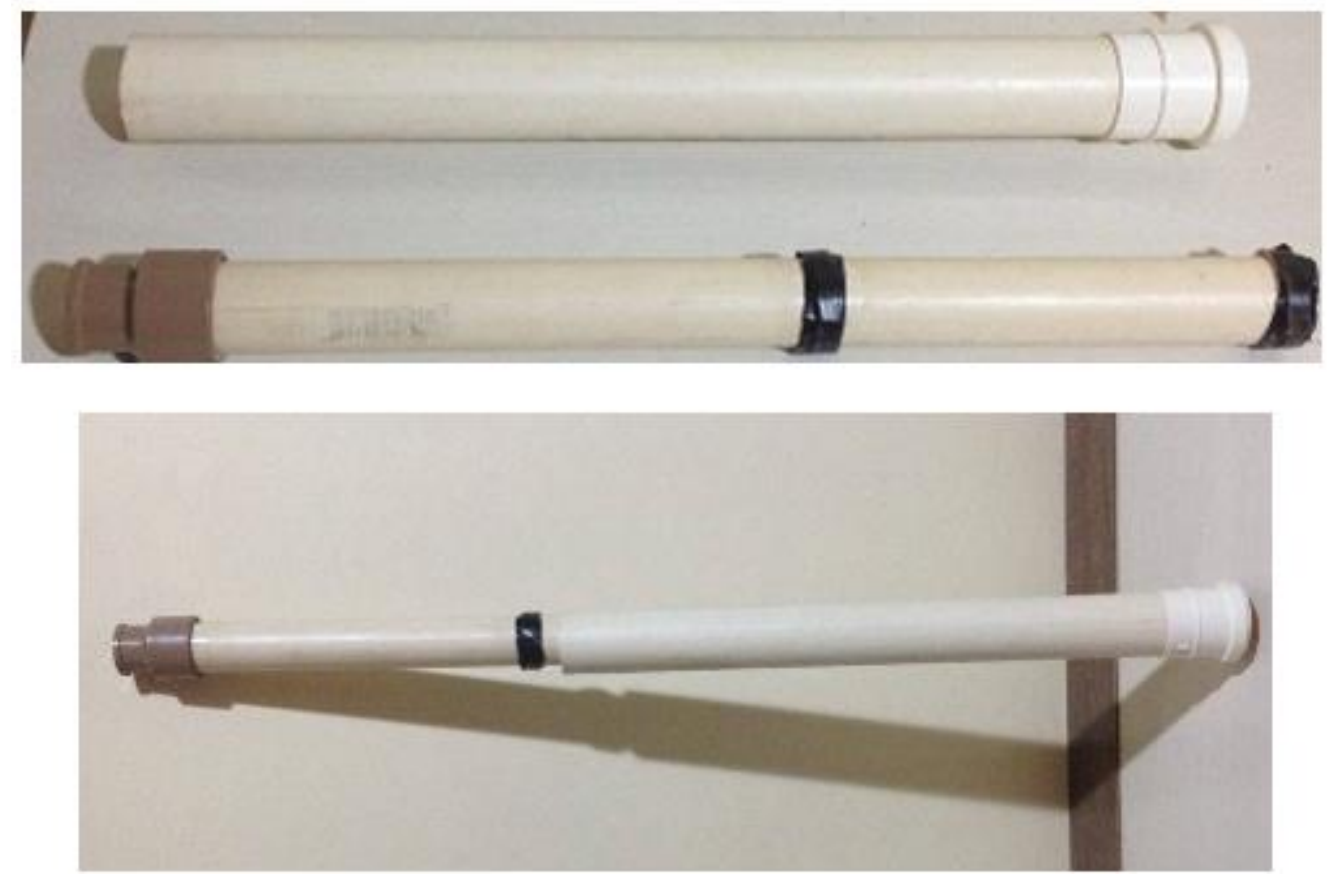

Figura 39: luneta montada

É importante pintar a luneta, de preferência com tinta spray da cor "preto fosco", principalmente por dentro dos tubos, para evitar reflexos de imagens nas paredes internas dos canos. 


\section{Lista de Exercícios}

\section{Exercícios 1}

1. O que acontece com a luz branca ao incidir num objeto amarelo?

2. Qual a cor que um observador irá enxergar um objeto amarelo quando iluminá-lo com uma luz policromática ciano?

3. O mesmo objeto amarelo agora será iluminado por uma luz policromática magenta, qual cor o observador irá enxergar?

4. Com auxílio do lápis de cor, pinte a bandeira brasileira quando ela for iluminada pela cor:

a) Amarela

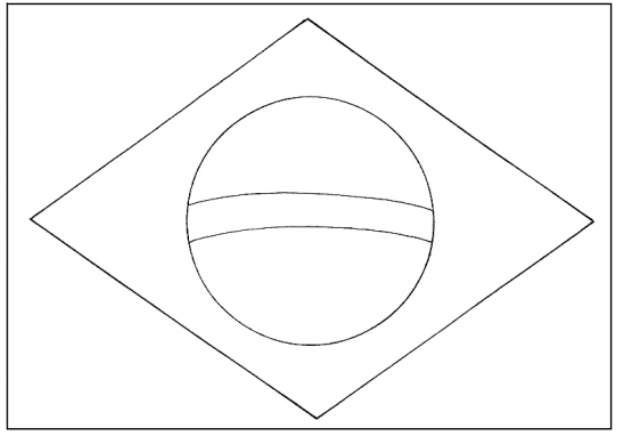

b) Vermelha

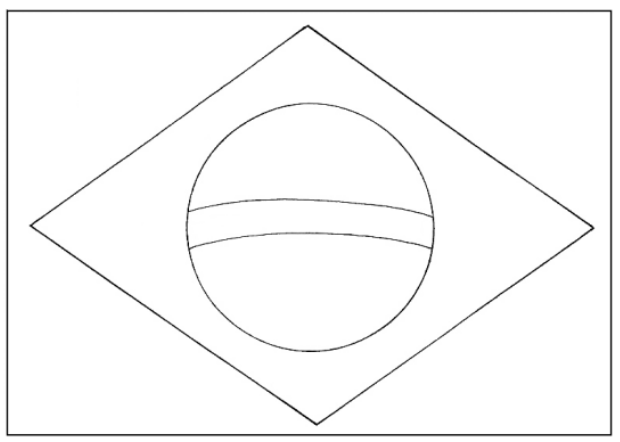

c) Azul

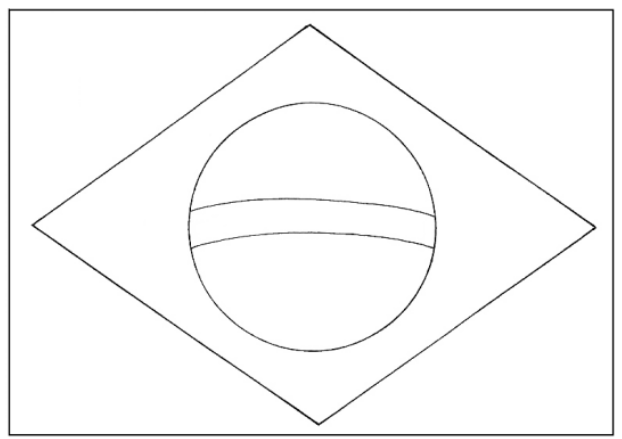


d) Verde

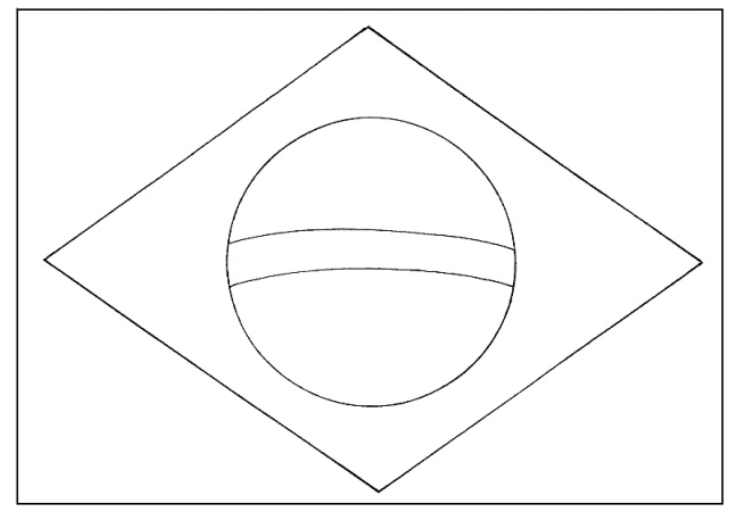

$\checkmark$ Exercícios 2

1. Nas figuras abaixo determine o valor de " $x$ ":

a)

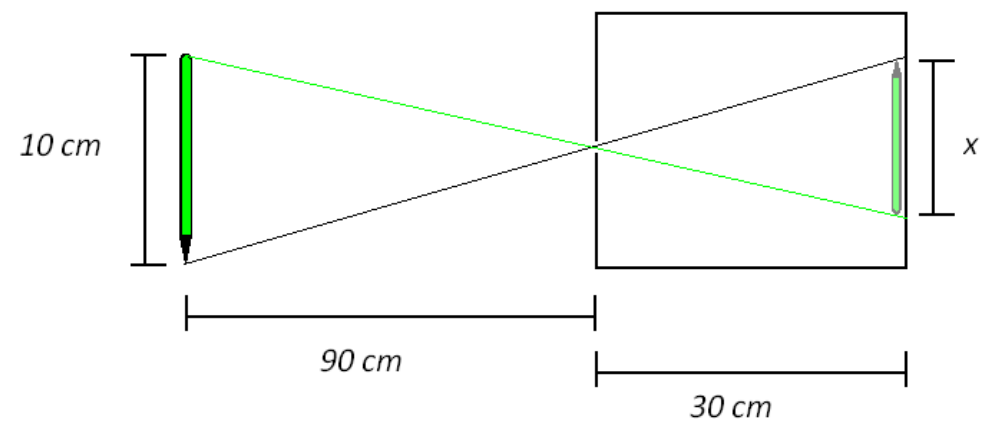

b)

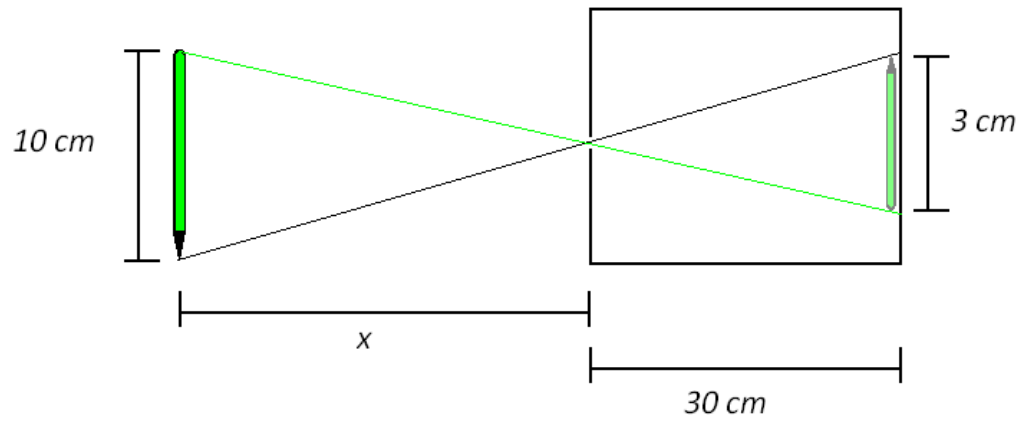

c)

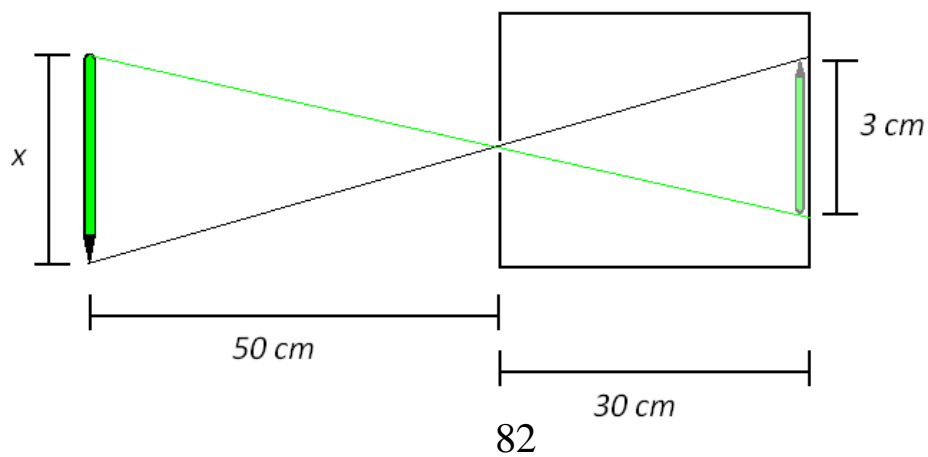


2. Quando o Sol é visualizado numa câmara escura quadrada de $1,0 \mathrm{~m}$ a imagem formada é de $9,0 \mathrm{~mm}$, como mostra o esquema na figura abaixo.

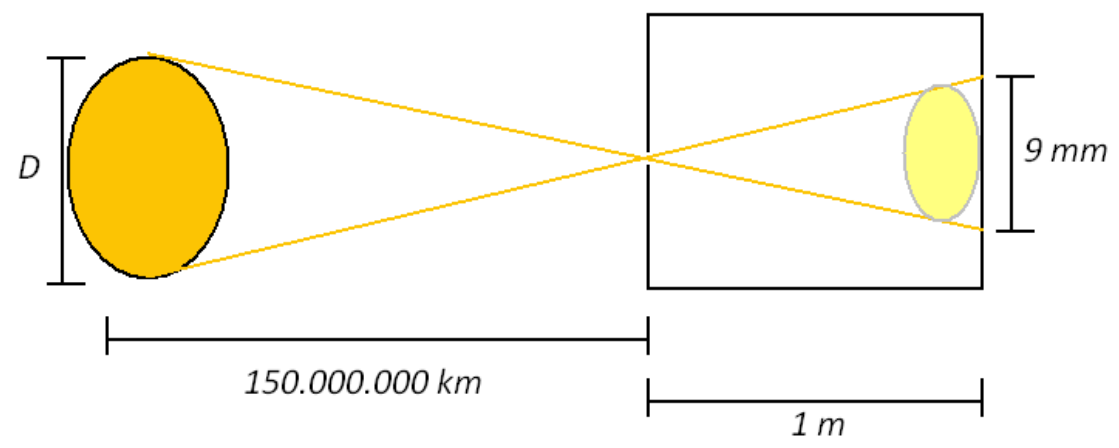

Sabendo que a distância da Terra ao Sol é de $150.000 .000 \mathrm{~km}$, determine o diâmetro do Sol.

\section{$\checkmark$ Exercícios 3}

1. Um objeto é colocado a $30 \mathrm{~cm}$ de um espelho côncavo de $10 \mathrm{~cm}$ de raio e curvatura. qual a posição da imagem e seu aumento linear transversal?

2. Ao se posicionar um objeto na frente de um espelho côncavo de $20 \mathrm{~cm}$ de raio de curvatura verificamos a formação de uma imagem invertida com o dobro do tamanho do objeto.

a) Qual a distância focal do espelho?

b) Qual o aumento linear transversal?

c) Qual posição do objeto e da imagem?

3. Na figura abaixo, o tamanho da imagem é a metade do tamanho do objeto. Qual a distância focal do espelho?

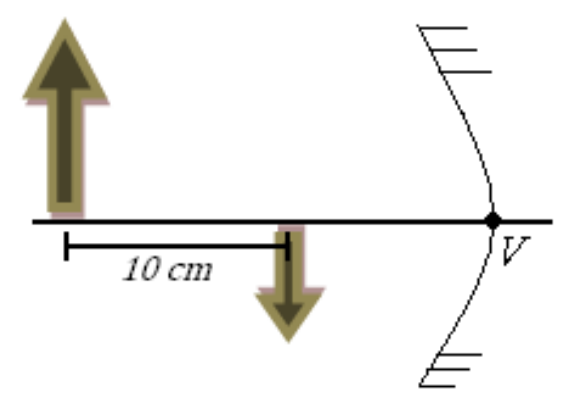


4. Um objeto de $10 \mathrm{~cm}$ de altura é colocado a $30 \mathrm{~cm}$ de um espelho convexo de $60 \mathrm{~cm}$ de raio de curvatura. Qual a posição e o tamanho da imagem?

5. Um objeto de $40 \mathrm{~cm}$ de altura é colocado a $20 \mathrm{~cm}$ de um espelho esférico formando uma imagem direita á $5 \mathrm{~cm}$ do espelho. Determine:
a) o tipo de espelho.
b) a distância focal do espelho.
c) o tamanho da imagem.

\section{$\checkmark$ Exercícios 4}

1. Na figura abaixo explique por que o lápis parece estar "quebrado".

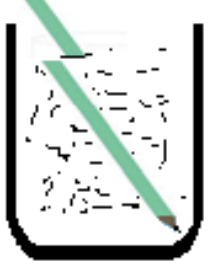

2. Pelo esquema abaixo determine o tipo de lente pelo formato.
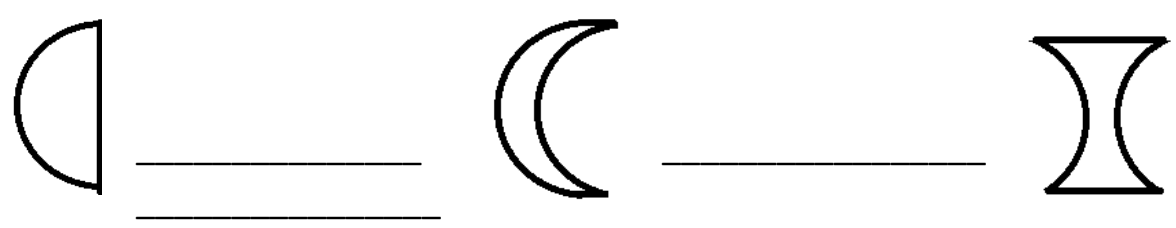

3. Os raios do Sol ao passar por uma lente convergente, se convergem a $10 \mathrm{~cm}$ de distância da lente. Se ao colocar um objeto a $20 \mathrm{~cm}$ desta lente, qual a distância da lente será formada a imagem?

4. Um objeto é colocado no mesmo plano óptico de uma lente convergente de distância focal $30 \mathrm{~cm}$. A imagem visualizada é direita e três vezes maior que o objeto. Sendo assim, determine a distância entre o objeto e a imagem

5. Na figura abaixo, o objeto de $10 \mathrm{~cm}$ de altura, está no mesmo plano óptico de uma lente convergente de distância focal de $15 \mathrm{~cm}$. À distância 
em que a imagem é formada é de $25 \mathrm{~cm}$ da lente. A qual a distância do objeto até a lente? Qual o aumento dessa lente?

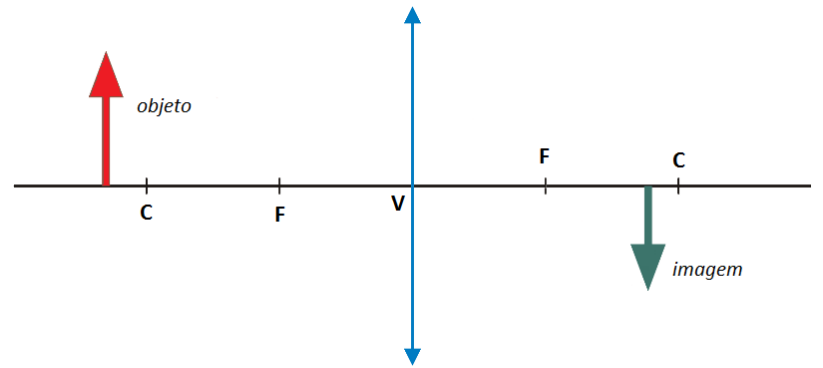




\section{Respostas das listas de Exercícios}

\section{$\checkmark$ Exercícios 1}

5. O corpo absorve a cor azul e reflete o vermelho e o verde.

6. O corpo absorve a cor azul e reflete o verde.

7. O corpo absorve a cor azul e reflete o vermelho.

8.

a)

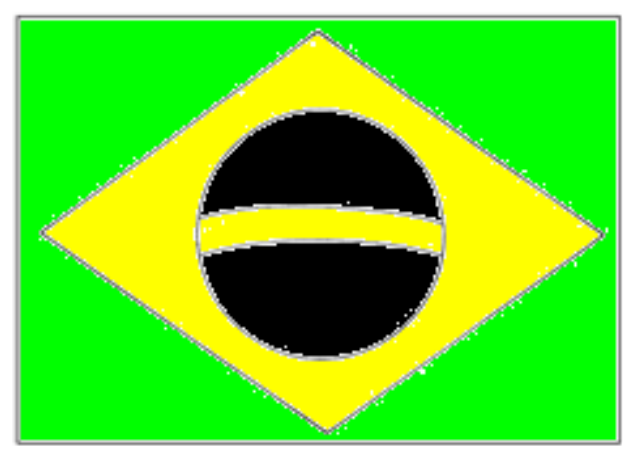

c)

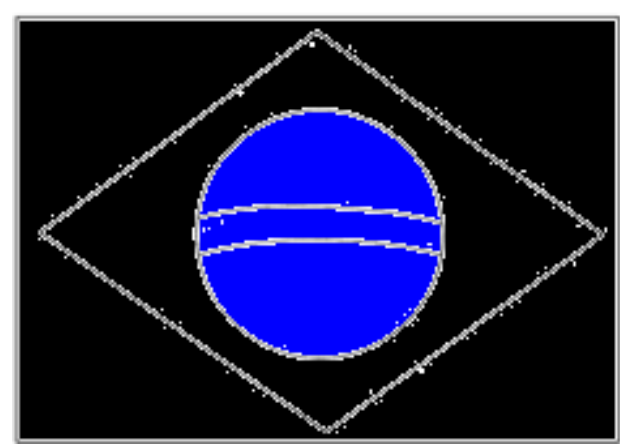

b)

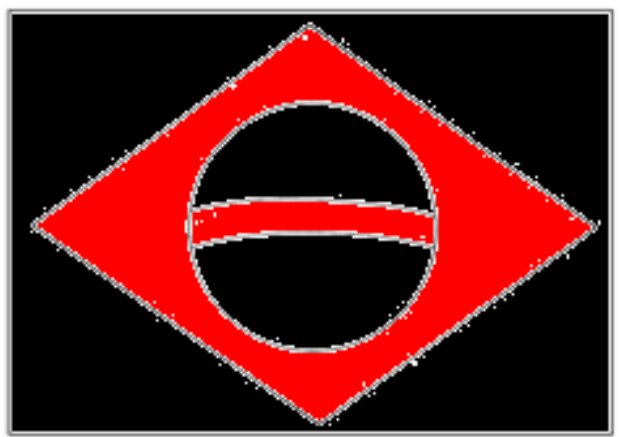

d)

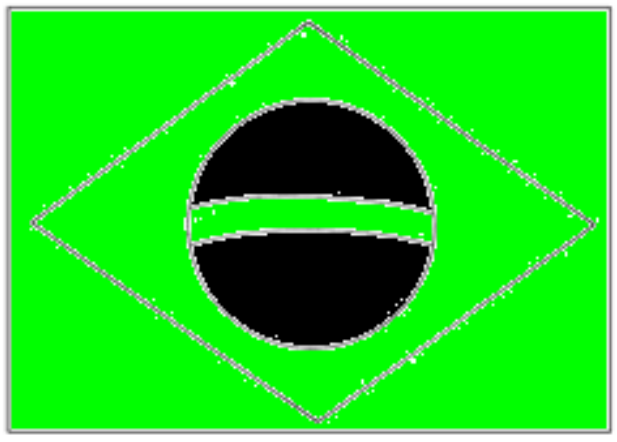

\section{$\checkmark$ Exercícios 2}

1.
a) $\frac{o}{p}=\frac{i}{p^{\prime}}$
$\frac{10}{90}=\frac{x}{30}$
$90 x=300$
$x=\frac{300}{90}$
$x=3,33 \mathrm{~cm}$
b) $\frac{o}{p}=\frac{i}{p^{\prime}} \quad \frac{10}{x}=\frac{3}{30} \quad 3 x=300$ 


$$
\begin{array}{rlrl}
x & =\frac{300}{3} \quad x & =100 \mathrm{~cm} \text { ou } x=1,0 \mathrm{~m} \\
\text { С) } \frac{o}{p} & =\frac{i}{p^{\prime}} \quad \frac{x}{50} & =\frac{3}{30} & 30 x=150 \\
x & =\frac{150}{3} & x & =50 \mathrm{~cm}
\end{array}
$$

2.

$$
\begin{array}{lc}
\mathrm{O}=\mathrm{D}=? & p=150.000 .000 \mathrm{~km} \text { ou } 1,5 \cdot 10^{11} \mathrm{~m} \\
p^{\prime}=1 \mathrm{~m} & i=9 \mathrm{~mm} \text { ou } 9 \cdot 10^{-3} \mathrm{~m} \\
\frac{o}{p}=\frac{i}{p^{\prime}} & \frac{D}{1,5 \cdot 10^{11}}=\frac{9 \cdot 10^{-3}}{1} \quad D=1,5 \cdot 10^{11} \cdot 9 \cdot 10^{-3} \\
& D=13,5 \cdot 10^{8} \mathrm{~m} \text { ou } D=1,35 \cdot 10^{9} \mathrm{~m}
\end{array}
$$

\section{$\checkmark$ Exercícios 3}

1.

$\frac{1}{f}=\frac{1}{p}+\frac{1}{p^{\prime}} \quad \frac{1}{5}=\frac{1}{30}+\frac{1}{p^{\prime}} \quad \frac{1}{p^{\prime}}=\frac{1}{5}-\frac{1}{30} \quad \frac{1}{p^{\prime}}=\frac{6-1}{30}$

$\frac{1}{p^{\prime}}=\frac{6-1}{30} \quad \frac{1}{p^{\prime}}=\frac{5}{30} \quad 5 p^{\prime}=30 \quad p^{\prime}=6 \mathrm{~cm}$

2.

a)

$$
f=\frac{c}{2} \quad f=\frac{20}{2} \quad f=10 \mathrm{~cm}
$$

b)

$$
A=\frac{i}{o} \quad A=\frac{2 . o}{o} \quad A=2 \text { ou } \quad A=200 \%
$$


c)

$\frac{i}{o}=-\frac{p \prime}{p} \quad 2=-\frac{p^{\prime}}{p} \quad 2 p=-p^{\prime}$

$\frac{1}{f}=\frac{1}{p}+\frac{1}{p^{\prime}} \quad \frac{1}{10}=\frac{1}{p}+\frac{1}{2 p} \quad \frac{1}{10}=\frac{2+1}{2 p} \quad 2 p=30 \quad \boldsymbol{p}=\mathbf{1 5} \mathrm{cm}$

3.

$i=\frac{o}{2} \quad \frac{1}{f}=\frac{1}{p}+\frac{1}{p^{\prime}} \quad p=p^{\prime}-10$

$\frac{i}{o}=-\frac{p \prime}{p} \rightarrow \frac{o / 2}{o}=-\frac{p-10}{p} \rightarrow \frac{1}{2}=\frac{-p+10}{p} \rightarrow p=-2 p+20 \rightarrow$

$\rightarrow \boldsymbol{p}=\mathbf{2 0} \mathrm{cm} \quad \rightarrow \quad p=p^{\prime}-10 \quad \rightarrow \quad 20=p^{\prime}-10 \quad \rightarrow \quad \boldsymbol{p}^{\prime}=\mathbf{1 0} \mathrm{cm}$

$\frac{1}{f}=\frac{1}{p}+\frac{1}{p^{\prime}} \rightarrow \frac{1}{f}=\frac{1}{20}+\frac{1}{10} \rightarrow \frac{1}{f}=\frac{2+1}{20} \rightarrow 3 f=20 \rightarrow f=6,66 \mathrm{~cm}$

4. Não há imagem formada.

5.

a) convexo

b)

$\frac{1}{f}=\frac{1}{p}+\frac{1}{p^{\prime}} \quad \frac{1}{f}=\frac{1}{20}-\frac{1}{5} \quad \frac{1}{f}=\frac{1-4}{20} \quad 3 f=20 \quad f=6,66 \mathrm{~cm}$

c)

$\frac{i}{o}=-\frac{p \prime}{p} \quad \frac{i}{40}=-\frac{-5}{20} \quad \frac{i}{40}=\frac{5}{20} \quad 20 i=200 \quad i=\frac{200}{20} \quad \boldsymbol{i}=10 \mathrm{~cm}$ 


\section{$\checkmark$ Exercícios 4}

1. A luz ao passar de um meio para o outro sofre a refração, e aos chegar em nossos olhos dá a impressão de estar quebrado.

2. Plano-convexa, côncavo-convexa, bi-côncava.

3.

$$
\begin{aligned}
& \frac{1}{f}=\frac{1}{p}+\frac{1}{p^{\prime}} \quad \frac{1}{10}=\frac{1}{20}+\frac{1}{p^{\prime}} \quad \frac{1}{10}-\frac{1}{20}=\frac{1}{p^{\prime}} \quad \frac{2}{20}-\frac{1}{20}=\frac{1}{p^{\prime}} \\
& \frac{1}{p^{\prime}}=\frac{1}{20} \quad p^{\prime}=20 \mathrm{~cm}
\end{aligned}
$$

4.

$$
\begin{aligned}
& i=3 o \quad-\frac{i}{o}=\frac{p^{\prime}}{p} \quad-\frac{3 o}{o}=\frac{p^{\prime}}{p} \quad p^{\prime}=-3 p \\
& \frac{1}{f}=\frac{1}{p}+\frac{1}{p^{\prime}} \quad \frac{1}{30}=\frac{1}{p}-\frac{1}{3 p} \quad \frac{1}{30}=\frac{3-1}{3 p} \quad \frac{1}{30}=\frac{2}{3 p} \\
& 3 p=60 \quad p=\frac{60}{3} \quad p=20 \mathrm{~cm} \\
& p^{\prime}=-3 p \quad p^{\prime}=-3 \cdot 20 \quad p^{\prime}=-60 \mathrm{~cm} \\
& d_{i o}=p-p^{\prime} \quad d_{i o}=20-(-60) \quad \boldsymbol{d}_{\text {io }}=80 \mathrm{~cm}
\end{aligned}
$$

5.

$$
\frac{1}{f}=\frac{1}{p}+\frac{1}{p^{\prime}} \quad \frac{1}{15}=\frac{1}{p}+\frac{1}{25} \quad \frac{1}{p}=\frac{1}{15}-\frac{1}{25} \quad \frac{1}{p}=\frac{5-3}{75}
$$$$
\frac{1}{p}=\frac{2}{75} \quad 2 p=75 \quad \boldsymbol{p}=\mathbf{3 7 , 5} \mathbf{c m}
$$

$$
A=\frac{i}{o}=-\frac{p^{\prime}}{p} \quad A=-\frac{-25}{37,5} \quad A=0,66
$$




\section{Bibliografia}

BONJORNO, José Roberto, RAMOS, Clinton Marcico, PRADO, Eduardo de Pinho, CASEMIRO, Renato. Física: Termologia, óptica, ondulatória, $2^{\circ}$ ano. FTD, São Paulo, 2013.

FíSICA BACHILLERATO: disponível em:< http://curso2012fisica.blogspot. com.br/p/4-ano-reflexion-y-refraccion-de-la-luz.html> acesso em agosto de 2015

FÍSICA INTERESSANTE: disponível em: <http://www.fisica-interessante. com/fisica-ondas-cores.html>. acesso em agosto de 2015.

PUBLIC DOMAIN PICTURES: disponível em <http://www.fisicainteressante.com/fisica-ondas-cores.html> acesso em julho de 2015

WINKMEDIA COMONS: disponível em: <https://commons.wikimedia. org/wiki/File:CamaraOscura.png> acesso em agosto de 2015 